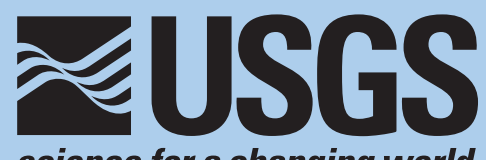

science for a changing world

Prepared in cooperation with the

Georgia Department of Natural Resources

Environmental Protection Division

\title{
Evaluation of Ground-Water Contribution to Streamflow in Coastal Georgia and Adjacent Parts of Florida and South Carolina
}

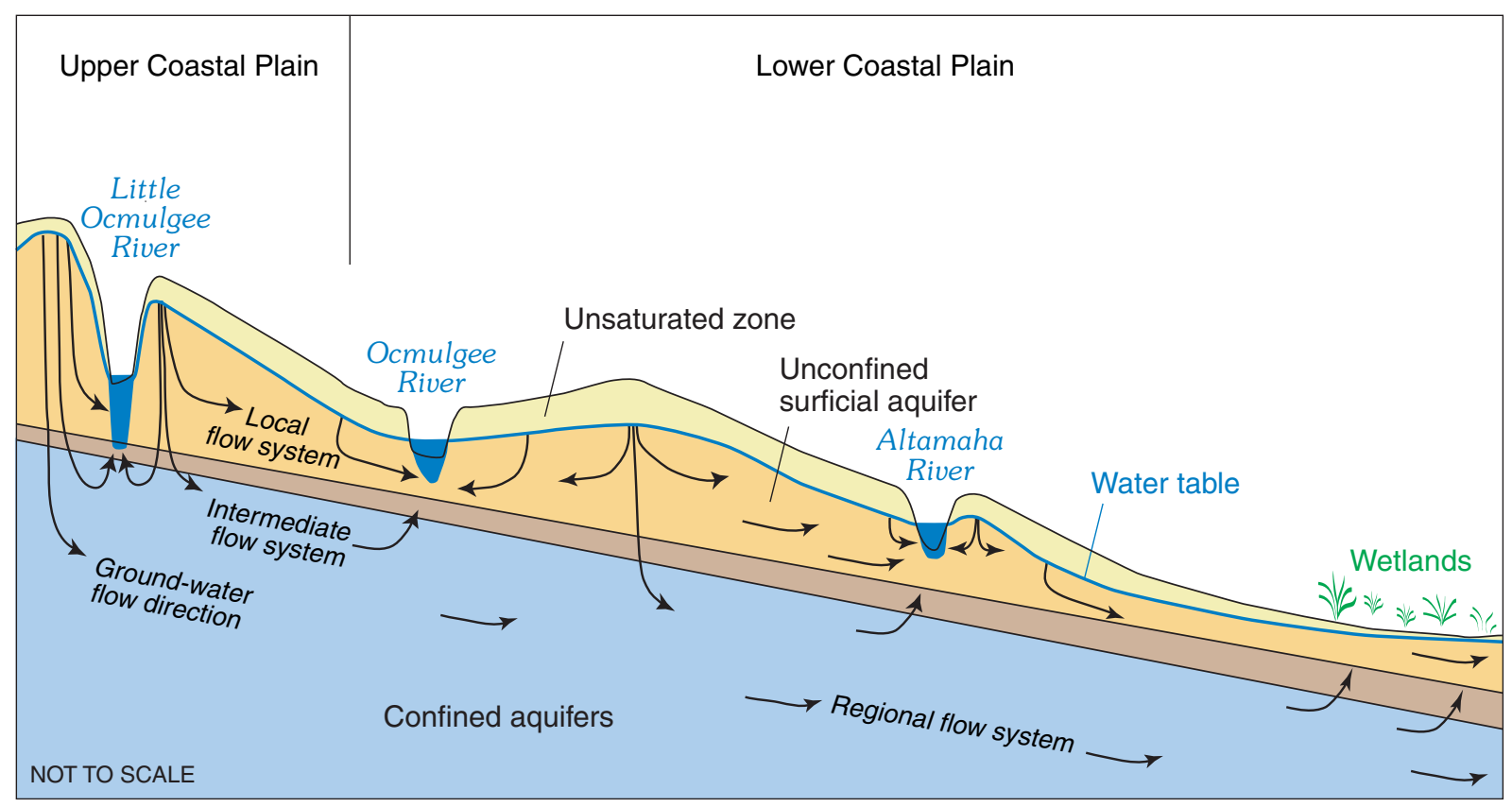

Scientific Investigations Report 2004-5265 



\section{Evaluation of Ground-Water Contribution to Streamflow in Coastal Georgia and Adjacent Parts of Florida and South Carolina}

By Sherlyn Priest

Prepared in cooperation with the

Georgia Department of Natural Resources

Environmental Protection Division

Scientific Investigations Report 2004-5265 


\section{U.S. Department of the Interior Gale A. Norton, Secretary \\ U.S. Geological Survey \\ Charles G. Groat, Director}

\section{U.S. Geological Survey, Reston, Virginia: 2004}

Atlanta, Georgia

This report is available online at http://pubs.usgs.gov/

For more information about the USGS and its products:

Telephone: 1-888-ASK-USGS

World Wide Web: http://www.usgs.gov/Any use of trade, product, or firm names in this publication is for descriptive purposes only and does not imply endorsement by the U.S. Government.

Although this report is in the public domain, permission must be secured from the individual copyright owners to reproduce any copyrighted materials contained within this report. 


\section{Contents}

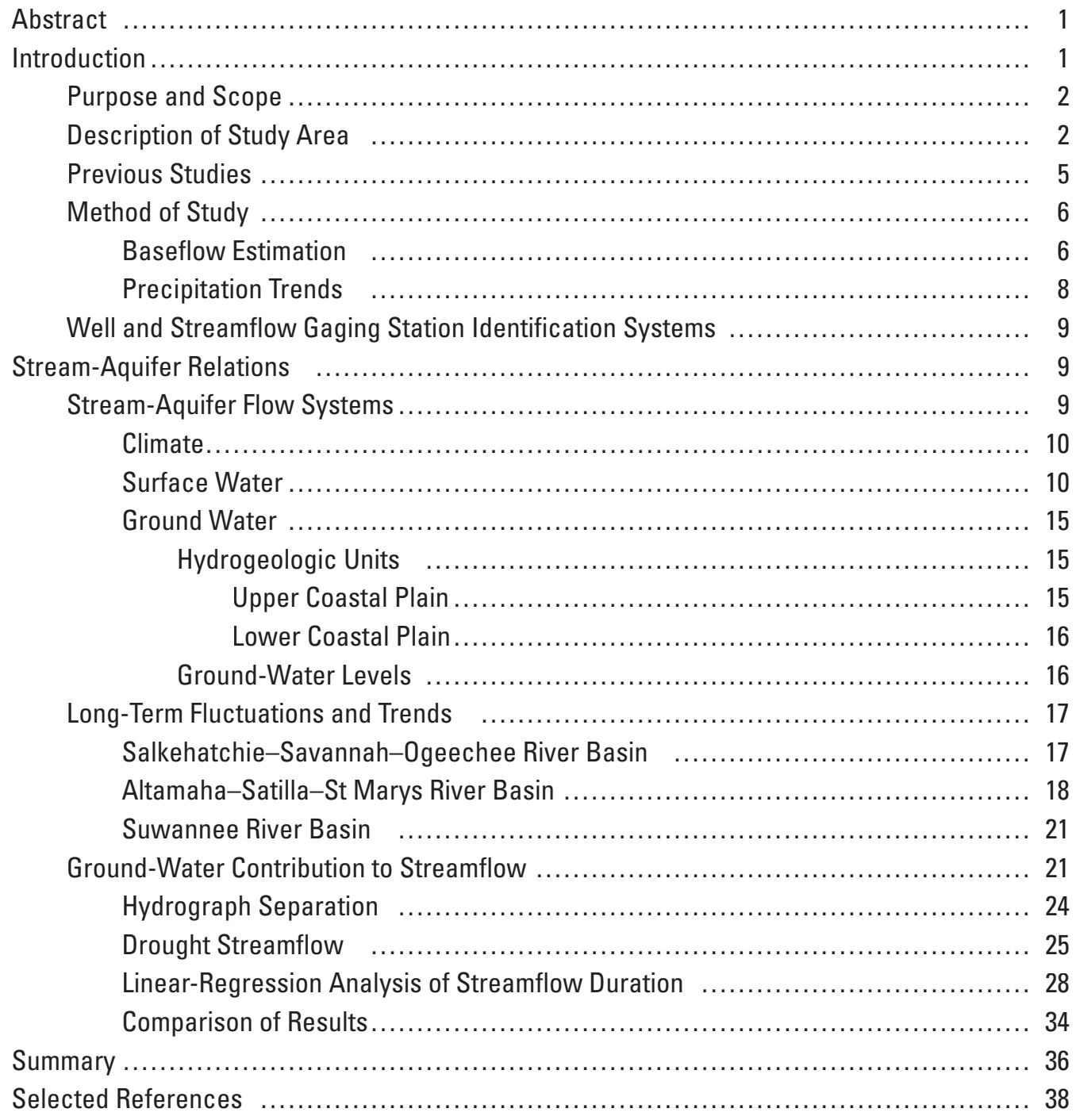




\section{Figures}

1. Map showing location of study area, streamflow gaging stations, wells, and

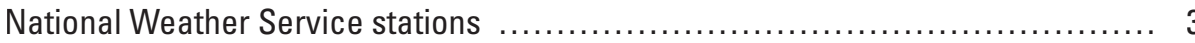

2. Chart showing geologic and hydrogeologic units of the upper and lower Coastal Plain, Georgia

3. Graphs of differences in separating baseflow using fixed-interval, sliding-interval, and local-minimum methods of HYSEP at Beaverdam Creek (station 02198100) near Sardis, Georgia, 1999

4. Schematic diagram of the conceptual hydrologic flow system in the upper and lower Coastal Plain of Georgia .....

5. Map showing mean annual precipitation for selected National Weather Service stations in the Coastal Plain of Georgia and South Carolina, 1971-2000

6. Graphs showing mean monthly precipitation at selected National Weather Service stations in the Coastal Plain area of Georgia and South Carolina, 1971-2001

7. Map showing mean annual runoff for the Coastal Plain of Georgia, 1941-70

8. Boxplots showing distribution of daily streamflow for Brier Creek (station 02198000) near Millhaven, Georgia; Canoochee River (station 02203000) near Claxton, Georgia; and Little Satilla River (station 02227500) near Offerman, Georgia, for the period of record

9-14. Graphs Showing-

9. Mean monthly streamflow at a selected streamflow gaging station within the Salkehatchie-Savannah-Ogeechee, Altamaha-Satilla-St Marys, and Suwannee River Basins for the periods of record

10. Daily water-level measurements in wells 35P094 and 360008, Chatham County; and daily rainfall at National Weather Service station, Savannah Municipal Airport, Chatham County, Georgia, 2001

11. Daily mean water levels in the surficial, upper Brunswick, and Upper Floridan aquifers at the Gardi site, Wayne County, Georgia, 1983-2001

12. Mean annual stream discharge, daily mean ground-water level, and cumulative departure from normal precipitation for the upper and lower parts of Salkehatchie-Savannah-Ogeechee River Basin, Georgia and South Carolina, 1971-2001

13. Mean annual stream discharge, daily mean ground-water level, and cumulative departure from normal precipitation for the upper and lower parts of the Altamaha-Satilla-St Marys River Basin, Georgia, 1971-2001

14. Mean annual stream discharge, daily mean ground-water level, and cumulative departure from normal precipitation for the upper and lower parts of the Suwannee River Basin, Georgia, 1971-2001... 22

15. Potentiometric surface of the Upper Floridan aquifer, May 1998 .................... 23

16. Baseflow separation using the local-minimum method for the wet, average, and dry years at Canoochee River (station 02203000) near Claxton, Georgia, 1971-2001

17. Comparison of drought streamflow between two adjacent streamflow gaging stations in the Salkehatchie-Savannah-Ogeechee River Basin 
18-20. Maps Showing-

18. Selected streamflow gaging stations monitored during the 1954 drought and

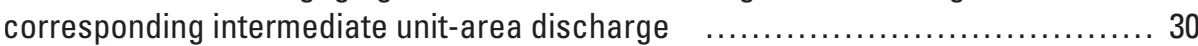

19. Selected streamflow gaging stations monitored during the 1981 drought and

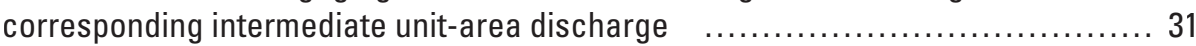

20. Selected streamflow gaging stations monitored during the 2000 drought and corresponding intermediate unit-area discharge

21-26. Graphs Showing-

21. Comparison of two flow-duration curve types: gentle curve along Brier Creek (station 02198000) and a steep curve along the Alapaha River (station 02317500) ... 33

22. Duration of mean daily streamflow for Brushy Creek (station 02197600) near Wrens, Georgia, and Brier Creek (station 02198000) at Millhaven, Georgia, 1971-2001....

23. Duration of mean daily streamflow for Canoochee River (station 02203000) near Claxton, Georgia, in the upper Salkehatchie-Savannah-Ogeechee River Basin, 1971-2001

24. Duration of mean daily streamflow for Little Satilla River (02227500) near Offerman, Georgia, and Ocmulgee River (02215500) at Lumber City, Georgia, in the Altamaha-Satilla-St Marys River Basin, 1971-2001

25. Duration of mean daily streamflow for Alapaha River (station 02317500) at Statenville, Georgia, in the Suwannee River Basin, 1971-2001

26. Regression of $\mathrm{O}_{35}$ versus mean annual baseflow for the 8 and 14 streamflow gaging stations selected for hydrograph-separation technique, Georgia and South Carolina, 1971-2001

\section{Tables}

1. Selected streamflow gaging and partial-record stations in SalkehatchieSavannah-0geechee, Altamaha-Satilla-St Marys, and Suwannee River Basins _.. 4

2. Well construction data for selected wells used in Georgia ...................... 6

3. Summary of mean annual baseflow estimated using HYSEP at selected streamflow gaging stations in the upper and lower parts of the basins in coastal Georgia and South Carolina, 1971-2001 f................................. 24

4. Measured stream discharge at selected streamflow gaging stations in the upper and lower Coastal Plain during the 1954, 1981, and 2000 droughts in Georgia and Florida

5. Estimated ground-water discharge to selected streams in the SalkehatchieSavannah-Ogeechee, Altamaha-Satilla-St Marys, and Suwannee River Basins during the 1954, 1981, and 2000 droughts

6. Flow-duration curve index $\left[\left(0_{25} / \mathrm{O}_{75}\right)^{1 / 2}\right]$ and curve shape for selected streams in the Salkehatchie-Savannah-Ogeechee, Altamaha-Satilla-St Marys, and Suwannee River Basins, 1971-2001

7. Coefficient of determination $\left(\mathrm{r}^{2}\right)$ and residual standard of error for flow durations evaluated as indicators of baseflow for 8 and 14 streamflow gaging stations selected in the Salkehatchie-Savannah-Ogeechee, Altamaha-Satilla-St Marys, and Suwannee River Basins, 1971-2001

8. Comparison of three methods used to calculate baseflow for selected streamflow gaging stations in the Salkehatchie-Savannah-Ogeechee, Altamaha-SatillaSt Marys and Suwannee River Basins, 1971-2001 


\section{Conversion Factors and Datum}

Temperature in degrees Celsius $\left({ }^{\circ} \mathrm{C}\right)$ may be converted to degrees Fahrenheit $\left({ }^{\circ} \mathrm{F}\right)$ as follows:

$$
{ }^{\circ} \mathrm{F}=\left(1.8 x^{\circ} \mathrm{C}\right)+32
$$

Temperature in degrees Fahrenheit $\left({ }^{\circ} \mathrm{F}\right)$ may be converted to degrees Celsius $\left({ }^{\circ} \mathrm{C}\right)$ as follows:

$$
{ }^{\circ} \mathrm{C}=\left({ }^{\circ} \mathrm{F}-32\right) / 1.8
$$

Vertical coordinate information is referenced to the North American Vertical Datum of 1988 (NAVD 88). Historical data collected and stored as National Geodetic Vertical Datum of 1929 have been converted to NAVD 88 for this publication.

Horizontal coordinate information is referenced to the North American Datum of 1983 (NAD 83). Historical data collected and stored as North American Datum of 1927 (NAD 27) have been converted to NAD 83 for use in this report. 


\title{
Evaluation of Ground-Water Contribution to Streamflow in Coastal Georgia and Adjacent Parts of Florida and South Carolina
}

\author{
By Sherlyn Priest
}

\section{Abstract}

Stream-aquifer relations in the coastal area of Georgia and adjacent parts of Florida and South Carolina were evaluated as part of the Coastal Georgia Sound Science Initiative, the Georgia Environmental Protection Division's strategy to protect the Upper Floridan aquifer from saltwater intrusion. Ground-water discharge to streams was estimated using three methods: hydrograph separation, drought-streamflow measurements, and linear-regression analysis of streamflow duration. Ground-water discharge during the drought years of 1954, 1981, and 2000 was analyzed for minimum ground-water contribution to streamflow. Hydrograph separation was used to estimate baseflow at eight streamflow gaging stations during the 31-year period 1971-2001. Six additional streamflow gaging stations were evaluated using linear-regression analysis of flow duration to determine mean annual baseflow. The study area centers on three major river systems-the SalkehatchieSavannah-Ogeechee, Altamaha-Satilla-St Marys, and Suwannee- that interact with the underlying ground-water system to varying degrees, largely based on the degree of incision of the river into the aquifer and on the topography. Results presented in this report are being used to calibrate a regional groundwater flow model to evaluate ground-water flow and streamaquifer relations of the Upper Floridan aquifer.

Hydrograph separation indicated decreased baseflow to streams during drought periods as water levels declined in the aquifer. Average mean annual baseflow ranged from 39 to 74 percent of mean annual streamflow, with a mean contribution of 58 percent for the period 1971-2001. In a wet year (1997), baseflow composed from 33 to 70 percent of mean annual streamflow. Drought-streamflow analysis estimated baseflow contribution to streamflow ranged from 0 to 24 percent of mean annual streamflow. Linear-regression analysis of streamflow duration estimated the $\mathrm{Q}_{35}$ (flow that is equaled or exceeded 35 percent of the time) as the most reasonable estimate of baseflow. The $\mathrm{Q}_{35}$, when compared to mean annual streamflow, estimated a baseflow contribution ranging from 65 to 102 percent of streamflow. The $\mathrm{Q}_{35}$ estimate tends to overestimate baseflow as evidenced by the baseflow contribution greater than 100 percent. Ground-water contributions to streamflow are greatest during winter when evapotranspiration is low, and least during summer when evapotranspiration is high. Baseflow accounted for a larger percentage of streamflow at gaging stations in the Salkehatchie-SavannahOgeechee River Basin than in the other two basins. This difference is due largely to the availability of data, proximity to the Piedmont physiographic province where the major rivers originate and are by supplied ground water, and proximity to the upper Coastal Plain where there is greater topographic relief and interconnection between streams and aquifers.

\section{Introduction}

Population growth, increased tourism, and sustained industrial activities in the coastal area of Georgia have affected the area's water resources and limited the availability of ground water. The principal source of water in the 24-county coastal Georgia area is the Upper Floridan aquifer, which underlies most of the Coastal Plain of Georgia, southwest South Carolina, southeast Alabama, and all of Florida (Miller, 1986). The Upper Floridan aquifer is an extremely permeable, high-yielding aquifer that was first developed in the 1880s and has been used extensively since. Saltwater contamination of the Upper Floridan aquifer at Brunswick, Ga., Jacksonville, Fla., and Hilton Head Island, S.C., also limit the availability of ground water in coastal Georgia (Krause and Clarke, 2001).

The Coastal Georgia Sound Science Initiative is a program of scientific and feasibility studies to support development of Georgia Environmental Protection Division's (GaEPD) final strategy to protect the Upper Floridan aquifer 
from saltwater contamination. In support of the Coastal Georgia Sound Science Initiative, the U.S. Geological Survey (USGS) - in cooperation with GaEPD_-is conducting studies to characterize and monitor ground-water flow and saltwater contamination; evaluate possible alternative sources of water to the Upper Floridan aquifer; simulate ground-water flow and movement of saltwater in response to various water-management approaches; and monitor changes in the hydrologic system. The study area includes southeast Georgia and adjacent parts of northeast Florida and southwest South Carolina (fig. 1).

As part of the Coastal Georgia Sound Science Initiative, ground-water discharge to streams was estimated for selected streams and rivers in a 67-county area of southeast Georgia, northeast Florida, and southwest South Carolina ( 55 counties in Georgia, 5 counties in Florida, and 7 counties in South Carolina). Results presented herein are being used to calibrate a regional ground-water flow model to evaluate ground-water flow and stream-aquifer relations of the Upper Floridan aquifer.

\section{Purpose and Scope}

This report describes stream-aquifer relations in the coastal area of Georgia and adjacent parts of Florida and South Carolina by estimating ground-water discharge to streams under a variety of climatic conditions. These estimates were made using hydrograph-separation techniques, droughtstreamflow measurements, and linear-regression analysis of streamflow duration. The estimated ground-water discharge is being used to calibrate a regional ground-water flow model to evaluate ground-water flow and stream-aquifer relations of the Upper Floridan aquifer.

Continuous-discharge records from eight streamflow gaging stations (stations) were used to estimate baseflow using hydrograph-separation techniques for the 31-year period from 1971 to 2001; and continuous-discharge records from an additional six stations were used to estimate baseflow using linear-regression analysis of streamflow duration for the same period. Historical streamflow data collected from 22 stations during the 1954 drought, 7 stations during the 1981 drought, and 19 stations during the 2000 drought were used to evaluate intermediate basin ground-water discharge during dry periods (table 1). Precipitation data from 11 National Weather Service (NWS) stations (National Oceanic and Atmospheric Administration, 2002) and ground-water levels from 9 USGS wells (table 2) were evaluated for long-term trends (1971-2001).

Several tributaries to major rivers-Altamaha, Ogeechee, Salkehatchie, Satilla, Savannah, St Marys, and Suwanneedrain the study area. Streamflow records for continuous-record stations and several partial-record stations along the major rivers and tributaries were used in the investigation. Stream-discharge measurements were taken at 18 continuous-record and partial-record stations from July 31 through August 2, 2000, and stream-discharge measurements from 24 continuousrecord stations were used to evaluate surface-water conditions (fig. 1 and table 1). Measurements from 24 partial-record stations and continuous-record stations were collected for 1954 and from 12 partial-record stations and continuousrecord stations for 1981. Data were collected from 62 continuous-record and partial-record stations on tributaries including synoptic measurements. Unless otherwise indicated, the primary source of data used in this report is the USGS National Water Information System (NWIS) (at http://waterdata.usgs. gov/ga/nwis/nwis). All data presented are by calendar year.

\section{Description of Study Area}

The GaEPD defines the coastal area of Georgia to include the 6 coastal counties and adjacent 18 counties, an area of about 12,240 square miles ( $\mathrm{mi}^{2}$ ) (fig. 1). To account for natural hydrologic boundaries used for model simulation, the study area has been expanded to $32,661 \mathrm{mi}^{2}$ and includes the 24 coastal counties and outlying 43 counties extending into northeast Florida and southwest South Carolina.

The study area is located in the northern part of the southeastern Coastal Plain of Georgia, South Carolina, and Florida (fig. 1). Coastal Plain geology consists of layers of sand, clay, limestone, and dolomite that range in age from Late Cretaceous through Holocene. The northern limit of these strata and the contact between Coastal Plain sediments and Piedmont crystalline rocks correspond approximately to the Fall Line (Clarke and Zisa, 1976), a physiographic boundary between the Piedmont and Coastal Plain. The various strata dip and progressively thicken from the Fall Line to the southeast. The sedimentary sequence unconformably overlies Paleozoic to Mesozoic igneous, metamorphic, and sedimentary rocks (Chowns and Williams, 1983).

Coastal Plain sediments consist of fluvial, deltaic, and marine coastal and shelf deposits (Prowell and others, 1985). Numerous marine transgressions and regressions have deposited, removed, and redistributed sediments in the study area and the vicinity (Colquhoun, 1981). Carter and Putnam (1977) divided the Coastal Plain physiographic province into upper and lower Coastal Plain. In the upper Coastal Plain in Richmond County, Ga., sediments predominantly consist of nonmarine siliciclastic sediments. Marine sediments are more abundant in the lower Coastal Plain and include carbonateshelf deposits in some Tertiary strata (Atkins and others, 1996).

The principal source of ground water for all uses in the coastal area is the Floridan aquifer system, consisting of the Upper and Lower Floridan aquifers (Miller, 1986; Krause and Randolph, 1989). Secondary sources of water include the surficial and Brunswick aquifer systems (Clarke, 2003), consisting of sand of Miocene to Holocene age. A generalized correlation chart of geologic and hydrologic units is shown in figure 2.

Land use primarily is urban in industrial areas and cities. Outside of these areas, land use is a mix of forest, wetlands, row crops, and pasture. Altitude ranges from sea level along the coast to about 400 feet (ft) near the Fall Line. 


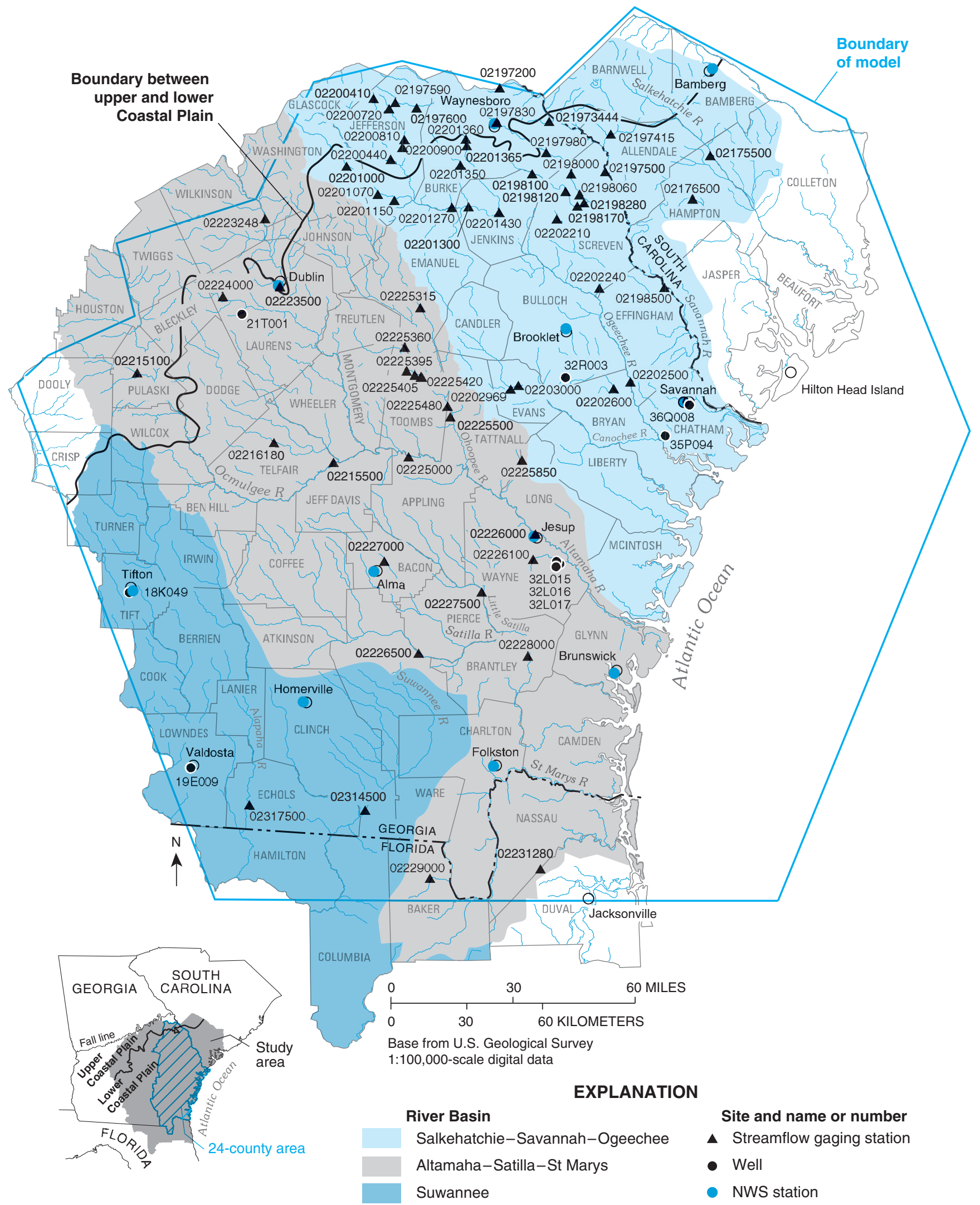

Figure 1. Location of study area, streamflow gaging stations, wells, and National Weather Service (NWS) stations. 
Table 1. Selected streamflow gaging and partial-record stations in Salkehatchie-Savannah-0geechee, Altamaha-Satilla-St Marys, and Suwannee River Basins.

[*, partial-record station; - , data not available; $\mathrm{mi}^{2}$, square miles; do., ditto]

\begin{tabular}{|c|c|c|c|c|}
\hline $\begin{array}{l}\text { Station } \\
\text { number }\end{array}$ & Station name & $\begin{array}{l}\text { Drainage area } \\
\qquad\left(\mathrm{mi}^{2}\right)\end{array}$ & County & Basin \\
\hline \multicolumn{5}{|c|}{ Salkehatchie-Savannah-Ogeechee River Basin } \\
\hline 02175500 & Salkehatchie River near Miley, S.C. & 341.00 & Hampton & Salkehatchie \\
\hline${ }^{1} 02176500$ & Coosawhatchie River near Hampton, S.C. & 203 & do. & do. \\
\hline 02197200* & McBean Creek (Ga. Hwy 56) at McBean, Ga & 71.4 & Burke & Savannah \\
\hline $021973444 *$ & Beaverdam Creek at River Rd near Girard, Ga. & 23.3 & do. & do. \\
\hline 02197415 & Lower Three Runs at Martin, S.C. & 109 & Allendale & do. \\
\hline 02197500 & Savannah River at Burtons Ferry Bridge, Millhaven, Ga. & 8,650 & Allendale/Screven & do. \\
\hline 02197590* & Brushy Creek at Wrens, Ga. & 9.4 & Jefferson & do. \\
\hline 02197600 & Brushy Creek near Wrens, Ga. & 28 & do. & do. \\
\hline 02197830* & Brier Creek near Waynesboro, Ga. & 473 & Burke & do. \\
\hline 02197980* & Brier Creek (Ga. Hwy 23) near Sardis, Ga. & 579 & do. & do. \\
\hline 02198000 & Brier Creek at Millhaven, Ga. & 646 & Screven & do. \\
\hline 02198060* & Brier Creek at US 301 near Sylvania, Ga. & 669 & do. & do. \\
\hline 02198100 & Beaverdam Creek near Sardis, Ga. & 30.8 & Burke/Jenkins & do. \\
\hline $02198120^{*}$ & Beaverdam Creek at Hilltonia, Ga. & 85.3 & Screven & do. \\
\hline 02198170* & Beaverdam Creek near Sylvania, Ga. & 116 & do. & do. \\
\hline 02198280* & Beaverdam Creek near Sylvania, Ga. & 143 & do. & do. \\
\hline 02198500 & Savannah River near Clyo, Ga. & 9,850 & Effingham & do. \\
\hline 02200410* & Duhart Creek (SR 80) at Stapleton, Ga. & 3.17 & Jefferson & Ogeechee \\
\hline $02200440^{*}$ & Rocky Comfort Creek (US 221) at Louisville, Ga. & 286 & do. & do. \\
\hline 02200720* & Big Creek (Penns Bridge Rd) near Wrens, Ga. & 8.07 & do. & do. \\
\hline 02200810* & Big Creek above Louisville, Ga. & 56.9 & do. & do. \\
\hline 02200900* & Big Creek near Louisville, Ga. & 95.8 & do. & do. \\
\hline 02201000 & Williamson Swamp Creek at Davisboro, Ga. & 109 & Washington & do. \\
\hline 02201070* & Williamson Swamp Creek at Bartow, Ga. & 185 & Jefferson & do. \\
\hline $02201150^{*}$ & Williamson Swamp Creek at Wadley, Ga. & 233 & do. & do. \\
\hline 02201270* & Barkcamp Creek (SR 17) near Midville, Ga. & 31.7 & Burke & do. \\
\hline $02201300^{*}$ & Chow Mill Creek near Herndon, Ga. & 23 & Jenkins & do. \\
\hline 02201350* & Buckhead Creek near Waynesboro, Ga. & 64 & Burke & do. \\
\hline 02201360* & Rocky Creek at SR 24 near Waynesboro, Ga. & 31.7 & do. & do. \\
\hline $02201365^{*}$ & Rocky Creek near Waynesboro, Ga. & 34.8 & Burke & Ogeechee \\
\hline 02201430* & Buckhead Creek at Millen, Ga. & 272 & Jenkins & do. \\
\hline 02202210* & Ogeechee Creek near Sylvania, Ga. & 14 & Screven & do. \\
\hline 02202240* & Ogeechee Creek near Oliver, Ga. & 141 & do. & do. \\
\hline 02202500 & Ogeechee River near Eden, Ga. & 2,650 & Effingham/Bryan & do. \\
\hline 02202600 & Black Creek near Blitchton, Ga. & 232 & Bryan & do. \\
\hline 02202969* & Cedar Creek (SR 129) at Claxton, Ga. & - & Evans & do. \\
\hline 02203000 & Canoochee River near Claxton, Ga. & 555 & do. & do. \\
\hline
\end{tabular}


Table 1. Selected streamflow gaging and partial-record stations in Salkehatchie-Savannah-0geechee, Altamaha-Satilla-St Marys, and Suwannee River Basins.-Continued

[*, partial-record station; - , data not available; $\mathrm{mi}^{2}$, square mile; do., ditto]

$\begin{array}{cccc}\begin{array}{c}\text { Station } \\ \text { number }\end{array} & \text { Station name } & \text { Drainage area } \\ \left(\mathrm{mi}^{2}\right) & \text { County }\end{array}$

Altamaha-Satilla-St Marys River Basin

\begin{tabular}{|c|c|c|c|c|}
\hline 02215100 & Tucsawhatchee Creek near Hawkinsville, Ga. & 163.00 & Pulaski & Altamaha \\
\hline 02215500 & Ocmulgee River at Lumber City, Ga. & 5,180 & Telfair/Jeff Davis & do. \\
\hline 02216180 & Turnpike Creek near McRae, Ga. & 49.2 & do. & do. \\
\hline 02223248 & Oconee River near Oconee, Ga. & 3,770 & Wilkins/Washington & do. \\
\hline 02223500 & Oconee River at Dublin, Ga. & 4,390 & Laurens & do. \\
\hline 02224000 & Rocky Creek near Dudley, Ga. & 62.9 & do. & do. \\
\hline 02225000 & Altamaha River near Baxley, Ga. & 11,600 & Toombs/Appling & do. \\
\hline $02225315^{*}$ & Jacks Creek near Wesley, Ga. & 8.63 & Emanual & do. \\
\hline $02225360 *$ & Pendleton Creek near Normantown, Ga. & 101 & Toombs/Emanual & do. \\
\hline $02225395^{*}$ & Swift Creek (SR 130) near Vidalia, Ga. & 36 & Toombs & do. \\
\hline $02225405^{*}$ & Swift Creek (US 1) near Lyons, Ga. & 46.3 & do. & do. \\
\hline $02225420 *$ & Swift Creek (SR 152) near Lyons, Ga. & 55.6 & do. & do. \\
\hline 02225480* & Ohoopee River (US 280) near Reidsville, Ga. & 1,070 & Tattnall/Toombs & do. \\
\hline 02225500 & Ohoopee River near Reidsville, Ga. & 1,110 & Tattnall & do. \\
\hline $02225850^{*}$ & Beards Creek near Glennville, Ga. & 74.4 & Long/Tattnall & do. \\
\hline 02226000 & Altamaha River at Doctortown, Ga. & 13,600 & Long/Wayne & do. \\
\hline 02226100 & Penholoway Creek near Jesup, Ga. & 209 & Wayne & do. \\
\hline 02226500 & Satilla River near Waycross, Ga. & 1,190 & Ware & Satilla \\
\hline 02227000 & Hurricane Creek near Alma, Ga. & 139 & Bacon & do. \\
\hline 02227500 & Little Satilla River near Offerman, Ga. & 646 & Wayne/Pierce & Satilla \\
\hline 02228000 & Satilla River at Atkinson, Ga. & 2,790 & Brantley & do. \\
\hline 02229000 & Middle Prong St Marys River at Taylor, Fla. & 125 & Baker & St Marys \\
\hline 02231280 & Thomas Creek near Crawford, Fla. & 29.9 & Duval/Nassau & do. \\
\hline
\end{tabular}

Suwannee River Basin

\begin{tabular}{llll}
02314500 & Suwannee River at Fargo, Ga. & 1,260 & Clinch \\
02317500 & Alapaha River at Statenville, Ga. & 1,390 & Echols \\
\hline
\end{tabular}

${ }^{1}$ For the purpose of this study, data from station 02716500 in the Broad-St Helen River Basin were included in the Salkehatchie-Savannah-Ogeechee River Basin.

\section{Previous Studies}

Hydrogeologic investigations of ground water in coastal Georgia include Miller (1986), who described the hydrogeologic framework of the Floridan aquifer system in Georgia, Florida, South Carolina, and Alabama; Krause and Randolph (1989), who simulated ground-water flow in the Floridan aquifer system in southeast Georgia and adjacent parts of South Carolina and Florida; and Clarke and others (1990), who described the geology and ground-water resources of 13 counties in the present study area.

Reports on stream-aquifer relations in the study area include Faye and Mayer (1990), who described streamaquifer relations and ground-water flow in the northern
Coastal Plain of Georgia and adjacent South Carolina and Alabama. Atkins and others (1996) estimated ground-water contribution to streams in the central Savannah River Basin using hydrograph-separation techniques and a droughtstreamflow analysis. Clarke and West $(1997,1998)$ simulated ground-water flow and stream-aquifer relations near the Savannah River Site in Georgia and South Carolina. Peck and others (2001) evaluated hydrogeologic conditions and pond-aquifer relations at two test sites in coastal Georgia. Abu-Ruman and Clarke (2001) described preliminary simulations of pond-aquifer interaction at a test site near Brunswick, Georgia. Mosner (2002) described stream-aquifer relations and the potentiometric surface of the Upper Floridan aquifer in southwest Georgia. 
Table 2. Well construction data for selected wells used in Georgia.

[ft, foot; altitude in feet below North American Vertical Datum 1988; screened or opened interval in feet below land surface; ’ , degree; ', minute; ", second]

\begin{tabular}{|c|c|c|c|c|c|c|c|c|}
\hline $\begin{array}{c}\text { Well } \\
\text { identification } \\
\text { number } \\
\text { (fig. 1) }\end{array}$ & Well name & County & Latitude & Longitude & $\begin{array}{l}\text { Altitude of } \\
\text { land surface } \\
\text { datum } \\
\text { (ft) }\end{array}$ & $\begin{array}{c}\text { Top of } \\
\text { screened or } \\
\text { open interval } \\
\text { (ft) }\end{array}$ & $\begin{array}{c}\text { Bottom of } \\
\text { screened or } \\
\text { open interval } \\
\text { (ft) }\end{array}$ & Aquifer \\
\hline 18K049 & $\begin{array}{l}\text { U.S. Geological Survey, } \\
\text { test well } 1\end{array}$ & Tift & $31^{\circ} 27^{\prime} 12^{\prime \prime}$ & $82^{\circ} 59^{\prime} 33^{\prime \prime}$ & 330.00 & 270 & 620 & Upper Floridan \\
\hline 19E009 & City of Valdosta & Lowndes & $30^{\circ} 49^{\prime} 51^{\prime \prime}$ & $83^{\circ} 16^{\prime} 58^{\prime \prime}$ & 217 & 200 & 342 & Upper Floridan \\
\hline 32L015 & $\begin{array}{l}\text { Georgia Geologic Survey, Gardi, } \\
\text { test well } 1\end{array}$ & Wayne & $31^{\circ} 32^{\prime} 52^{\prime \prime}$ & $81^{\circ} 43^{\prime} 36^{\prime \prime}$ & 74 & 545 & 750 & Upper Floridan \\
\hline 32L016 & $\begin{array}{l}\text { Georgia Geologic Survey, Gardi, } \\
\text { test well } 2\end{array}$ & Wayne & $31^{\circ} 32^{\prime} 52^{\prime \prime}$ & $81^{\circ} 43^{\prime} 36^{\prime \prime}$ & 74 & 320 & 340 & Upper Brunswick \\
\hline 32L017 & $\begin{array}{l}\text { Georgia Geologic Survey, Gardi, } \\
\text { test well } 3\end{array}$ & Wayne & $31^{\circ} 32^{\prime} 52^{\prime \prime}$ & $81^{\circ} 43^{\prime} 36^{\prime \prime}$ & 74 & 200 & 215 & Surficial \\
\hline 36Q008 & Layne-Atlantic Company & Chatham & $32^{\circ} 05^{\prime} 30^{\prime \prime}$ & $81^{\circ} 08^{\prime} 50^{\prime \prime}$ & 9.91 & 250 & 406 & Upper Floridan \\
\hline
\end{tabular}

Since 1977, the USGS has described ground-water levels annually in reports for selected wells in Georgia. The most recent of these reports described ground-water conditions in Georgia for 2002, including annual and period-of-record water-level fluctuations and trends for wells in the 67-county study area (Leeth and others, 2003). Peck and others (1999) described the potentiometric surface of the Upper Floridan aquifer in Georgia and adjacent parts of Alabama, Florida, and South Carolina, and water-level trends in Georgia during 1990-98. Fanning $(1999 ;$ 2003) described water use in coastal Georgia during 1980-97 and 1980-2000, respectively.

Streamflow conditions are described annually in Georgia in the report series, "Water resources data for Georgia." The most recent of these reports described streamflow conditions in Georgia during 2002, including records for 62 stations in the study area (Hickey and others, 2002; Coffin and others, 2002). Thomson and Carter (1955) reported effects of drought on streamflow for the 1954 drought; Carter (1983) for the 1980-81 drought; and Hale and others (1989) for the 1986 drought.

\section{Method of Study}

This study includes several work elements to estimate the ground-water discharge to streams under a variety of climatic conditions. The work includes compiling discharge, precipitation, and water-level data; separation of streamflow hydrographs to estimate mean annual ground-water contribution to streams; and evaluation of streamflow records and periodic discharge measurements during drought periods 1954, 1981, and 2000 , to estimate minimum values of ground-water discharge. Comparison of data was made between the upper and lower Coastal Plain when data were available. When no or few data were available, comparison was made between the upper and lower parts of the basins within the study area. This is an informal division done solely for comparison in this report.

Literature review provided information necessary to describe a conceptual model of stream-aquifer relations. Much of the conceptual model is based on results of previous investigations by Toth $(1962 ; 1963)$, Freeze and Witherspoon (1966; 1967; 1968), Faye and Mayer (1990), Atkins and others (1996), and Clarke and West (1998). These studies show that large rivers and their tributaries function as hydraulic drains for ground-water flow; and that during severe droughts, most of the discharge in these streams is contributed by ground water.

\section{Baseflow Estimation}

During periods of little or no rainfall, streamflow is assumed to be composed almost entirely of ground water (baseflow). As a result, the amount of streamflow contributed by ground water can be estimated. Three methods were used to estimate ground-water contribution to streamflow: hydrograph separation, field measurements during droughts, and linear-regression analysis of streamflow duration. Baseflow was estimated at eight stations using HYSEP (Sloto and Crouse, 1996), a computer program that separates the streamflow hydrographs into baseflow and surface-runoff components. The method for streamflow hydrograph separation used by this program was adapted from Pettyjohn and Henning (1979) and uses streamflow data in standard USGS daily values format. 


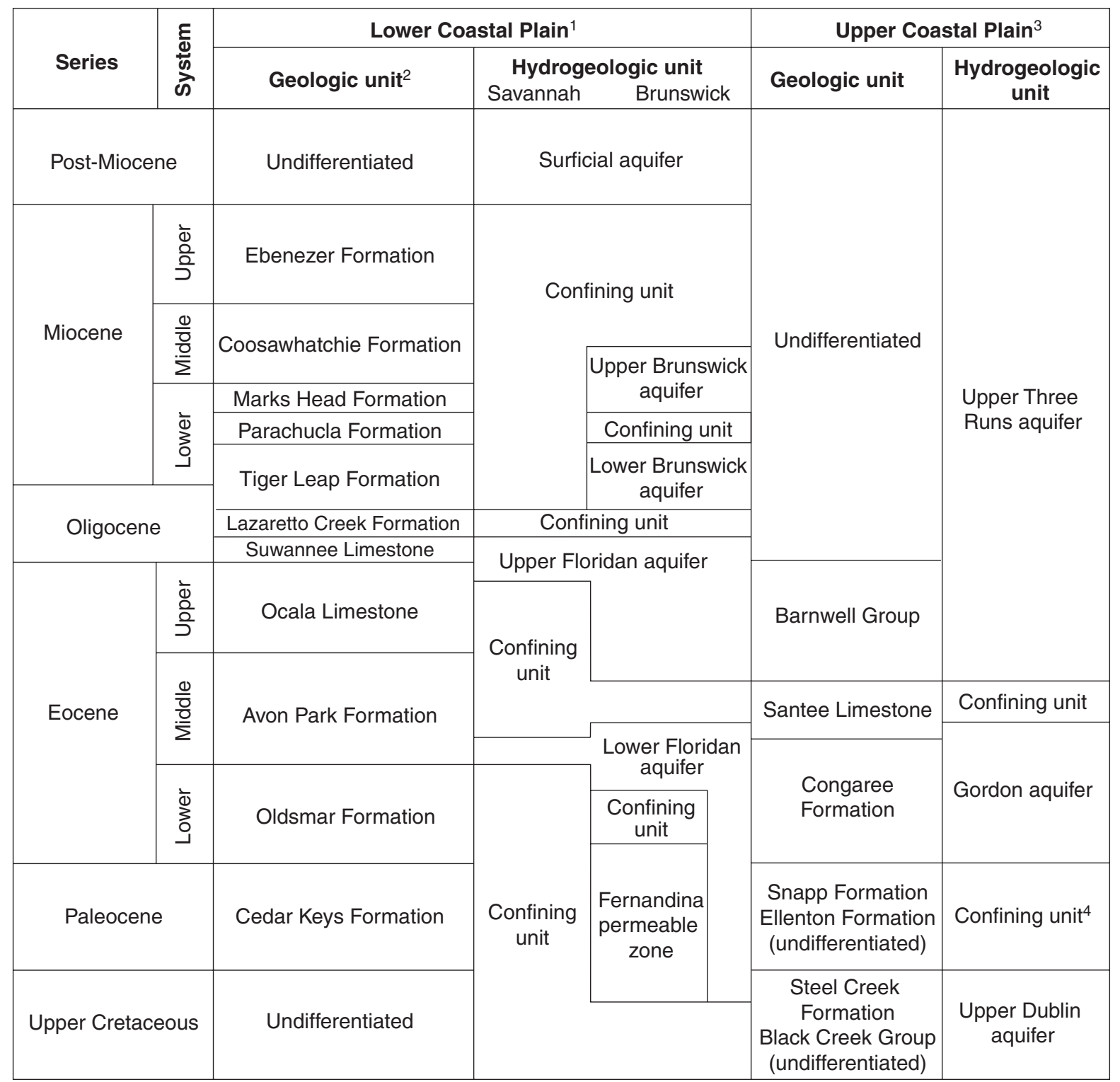

1/Modified from Randolph and others, 1991; Clarke and Krause, 2000.

2/Modified from Randolph and others 1991; Weems and Edwards, 2001.

3/Modified from Falls and others, 1997.

4/In local areas includes Millers Pond aquifer.

Figure 2. Geologic and hydrogeologic units of the upper and lower Coastal Plain, Georgia.

HYSEP uses three methods to separate baseflow: fixed interval, sliding interval, and local minimum (fig. 3). Each method uses a different algorithm to separate baseflow systematically from runoff by connecting low points on the streamflow hydrograph (Sloto and Crouse, 1996). The duration of surface runoff is calculated from the empirical relation:

$$
\mathrm{N}=\mathrm{A}^{0.2} \text {, }
$$

where $\mathrm{N}$ is the number of days for the cessation of runoff, and $\mathrm{A}$ is the drainage area of the basin (Linsley and others, 1982). All three methods use an algorithm based on the interval $2 \mathrm{~N}^{*}$, which is the odd integer between 3 and 11 that is nearest to
2N (Pettyjohn and Henning, 1979). The three methods as described by Sloto and Crouse (1996) are:

- The fixed-interval method assigns the lowest discharge in each $2 \mathrm{~N}^{*}$ interval to all days in that interval starting with the first day of the period of record.

- The sliding-interval method finds the lowest discharge in one-half the interval minus 1 day [0.5 $\left(2 \mathrm{~N}^{*}-1\right)$ days] prior to and after the day being considered and assigns the discharge value to that day; overlapping of intervals is allowed. 
- The local-minimum method checks each day to determine whether the discharge is the lowest discharge in one-half the interval minus 1 day $\left[0.5\left(2 \mathrm{~N}^{*}-1\right)\right.$ days]; overlapping of intervals is not allowed.

Mosner (2002) compared the results of the three methods using four basins in southwest Georgia and found that the fixed-interval and sliding-interval methods are biased toward baseflow; and thus, overpredict ground-water contribution to streamflow. A plot of the three methods of hydrograph separation for Beaverdam Creek (station 02198100) near Sardis, Ga., is shown in figure 3 . The plot shows the overestimation of the fixed-interval and sliding-interval methods; for this reason, the local-minimum method was used to estimate baseflow in the study area.

Surface-water discharge measurements collected during the three drought periods—1954, 1981, and 2000—were used to estimate baseflow for selected tributaries of the Salkehatchie-Savannah-Ogeechee (SSO) River, AltamahaSatilla-St Marys (SAS) River and Suwannee River Basins. The minimum ground-water discharge to tributaries between two adjacent reaches during the 1954 (22 stations), 1981 (7 stations), and 2000 (19 stations) drought years were collected from continuous-record stations and periodic discharge measurements. Unit-area ground-water discharge was measured for 24 stations during 1954, 12 stations during 1981, and 24 stations during 2000 within the three major basins. Drought year 1986 was not used in this evaluation because the drought effect on streamflow in this region was minor compared to other droughts.

Linear-regression analysis was used to determine the flow duration that most closely estimates baseflow in the study area. Flow duration is a cumulative frequency curve that shows the percentage of time a specific discharge was equaled or exceeded during a given period of time. Flow-duration curves integrate the effects of topography, geology, and climate of the basin. For example, baseflow of streams in the glacial till/ outwash of Long Island was estimated from 55-percent flow duration (Reynolds, 1982); whereas in the southeastern sand aquifer, baseflow was estimated to range between 60-65 percent of mean annual streamflow (Stricker, 1983). Mean annual baseflow for 14 stations in the study area was compared to flow durations ranging from $\mathrm{Q}_{1}$ to $\mathrm{Q}_{y 9}$ (streamflow equaled or exceeded 1 percent to 99 percent of the time) to derive flow duration that is representative of baseflow. This flow duration can be applied to streams in the study area to estimate baseflow for a given period.

\section{Precipitation Trends}

National Weather Service stations within the upper and lower parts of the SSO, SAS, and Suwannee River Basins were selected to estimate how long-term variations in precipitation affect fluctuations in streamflow and ground-water levels. The cumulative departure from normal precipitation for

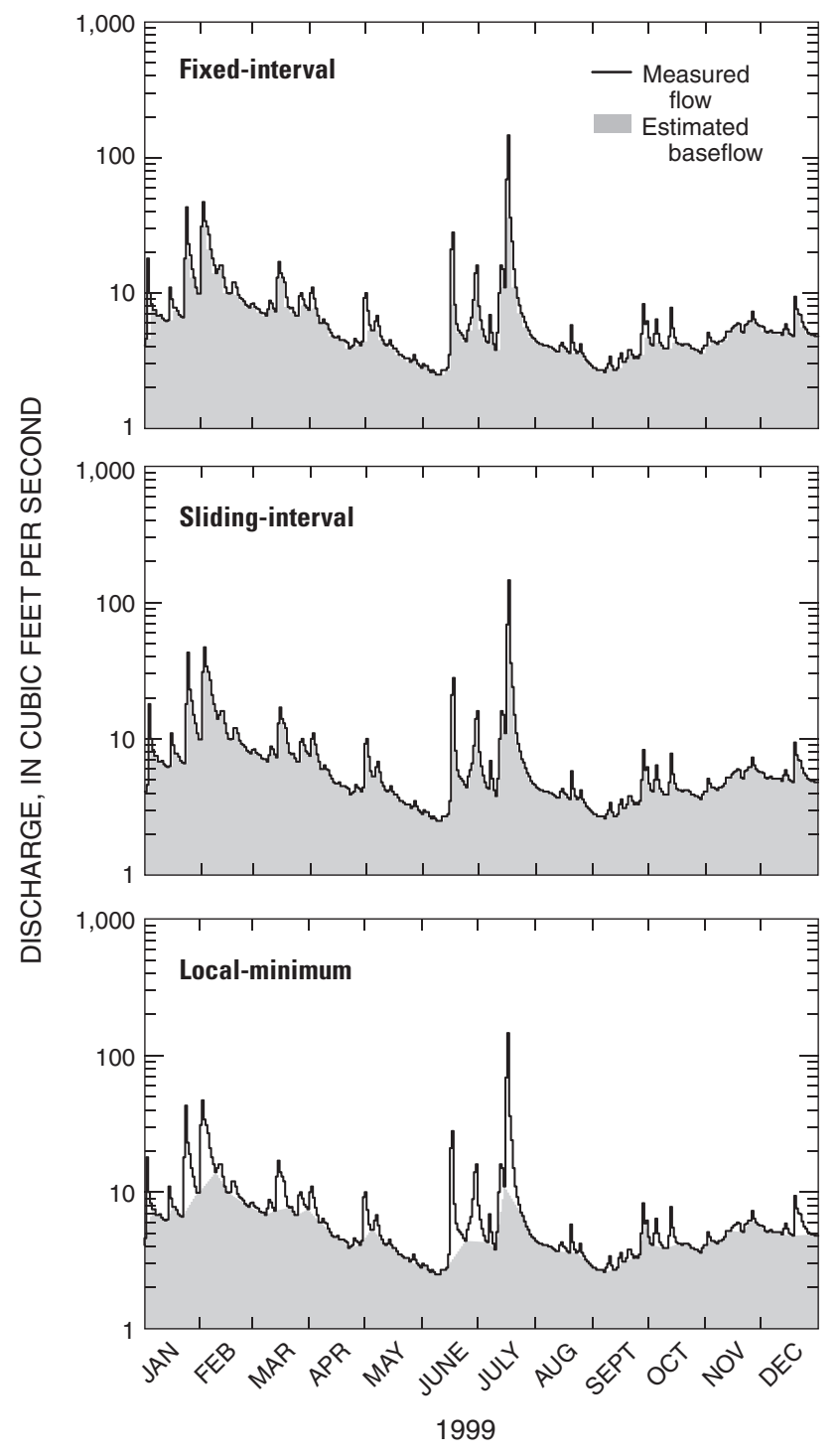

Figure 3. Differences in separating baseflow using fixed-interval, sliding-interval, and local-minimum methods of HYSEP at Beaverdam Creek (station 02198100) near Sardis, Georgia, 1999.

the period 1971-2001 was used to evaluate any trends in the precipitation. Cumulative departure describes the long-term surplus or deficit of precipitation during a designated period, and is derived by adding successive monthly values of departures from normal precipitation. Normal precipitation for a given month is defined as the average of total monthly precipitation during a specified 30-year period (National Oceanic and Atmospheric Administration, 2002); for this report, the period 1971-2000 was used to determine normal precipitation for computation of cumulative departure. Average precipitation is the arithmetic mean of total monthly precipitation for the period of study 1971-2001. 


\section{Well and Streamflow Gaging Station Identification Systems}

Wells in Georgia are identified by a system based on USGS topographic maps. Each 71/2-minute topographic quadrangle map in Georgia has been assigned a number and letter designation beginning at the southwest corner of the State. Numbers increase sequentially eastward through 39; letters advance northward through " $\mathrm{Z}$," then double-letter designations "AA" through "PP" are used. The letters "I," "O," "II," and "OO" are not used. Wells inventoried in each quadrangle are numbered sequentially beginning with " 1 ." Thus, the second well inventoried in the Folkston quadrangle (29E) is designated 29E002.

Stations are assigned an 8- to 14-digit station identification number according to downstream order along the main stream. The first two digits of the station identification number represent the "Part" number with the remaining digits representing the downstream order number. All stations on a tributary entering upstream from a mainstream station are listed before that station. A station on a tributary that enters between two mainstream stations is listed between them. A similar order is followed in listing stations on first rank, second rank, and other ranks of tributaries. Gaps are left in the series of numbers to allow for new stations that may be established; hence, the numbers are not consecutive.

\section{Stream-Aquifer Relations}

Water in streams and aquifers interact within a dynamic hydrologic system that includes aquifers, streams, reservoirs, and floodplains. These systems are interconnected and form a single hydrologic entity that is stressed by natural hydrologic, climatic, and anthropogenic factors.

\section{Stream-Aquifer Flow Systems}

Under steady-state conditions, most ground-water systems can be divided into three subsystems: local, intermediate, and regional (Toth, 1962; 1963). Relatively shallow and short flowpaths that extend from a topographic high (recharge area) to an adjacent topographic low (discharge area) characterize a local flow system. Intermediate flowpaths include at least one local flow system between their respective points of recharge and discharge, and are longer and deeper than local flowpaths. Regional flowpaths begin at or near a major ground-water divide and terminate at a regional drain (fig. 4).

The number, distribution, and depth of influence of local flow regimes are largely a function of water-table configuration and aquifer thickness relative to watershed relief (Faye and Mayer, 1990). Where aquifer sediments are thin, local flow systems may dominate. Local flow systems are affected

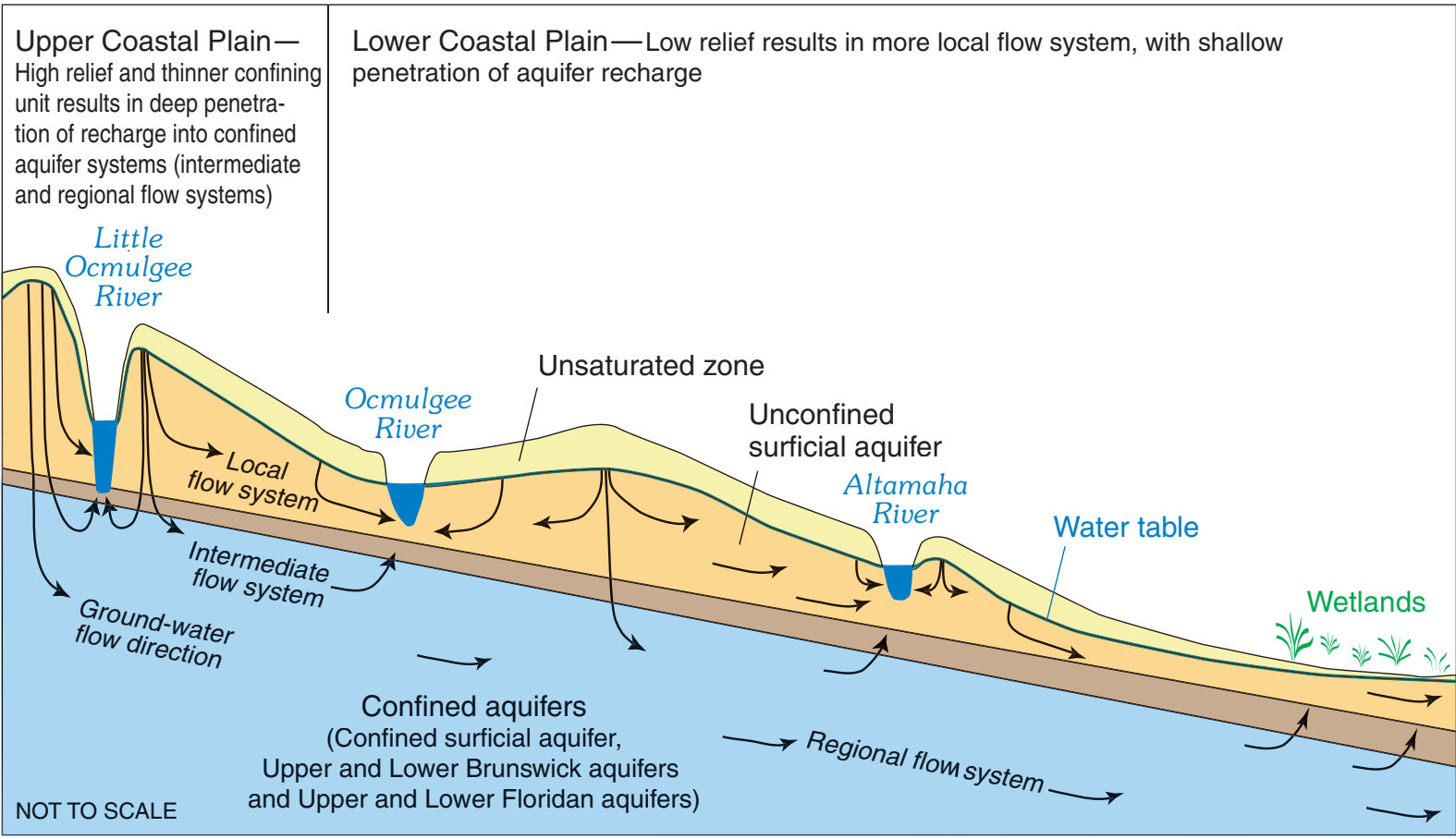

Figure 4. Schematic diagram of the conceptual hydrologic flow system in the upper and lower Coastal Plain of Georgia (modified from Toth, 1962; 1963). 
mostly by climatic variations. The net recharge and amount of ground-water flow are distributed according to the flow system, with flow and net recharge being greatest in local flow systems and least in regional flow systems (Toth, 1963). Local flow systems are most dynamic in areas of high relief such as the upper Coastal Plain (fig. 4).

In the study area, recharge to the hydrologic system is provided by rainfall that ranges spatially from an average of about 47 to 53 inches per year (in/yr), based on mean annual precipitation for the 30-year period 1971-2000 (fig. 5). Most of the recharge is discharged from the shallow, local flow systems into small streams or is lost as evapotranspiration. In the intermediate flow system, some of the water is discharged to major tributaries. A smaller percentage of recharge infiltrates through clayey confining units and enters the deeper regional flow system (Clarke and West, 1997). In the regional flow system, some of the water discharges to the Savannah and Altamaha River valleys and some flows southward discharging into the Atlantic Ocean. Faye and Mayer (1990) estimated mean annual ground-water discharge to the Savannah River by computing the gain in stream discharge between Augusta (station 02197000) and Millhaven (station 02197500). This estimate includes contribution from surface runoff and should be considered to represent the maximum aquifer discharge for that reach. Faye and Mayer (1990) estimated a gain of 660 cubic feet per second $\left(\mathrm{ft}^{3} / \mathrm{s}\right)$ from combined intermediate and regional flow systems and a gain of $560 \mathrm{ft}^{3} / \mathrm{s}$ from the local flow system. Baseflow was estimated by a modified hydrograph-separation technique to be $1,220 \mathrm{ft}^{3} / \mathrm{s}$. Thus, in the Savannah River Basin about 54 percent of ground-water recharge entered the intermediate and regional flow systems, and the remaining 46 percent entered the local flow system (Faye and Mayer, 1990). The local and intermediate flow systems affect much of the stream discharge in the northern part of the study area, and the intermediate and regional flow systems affect stream discharge in the southern part of the study area.

In the upper Coastal Plain, where relief is relatively high, local flow systems dominate. In upland areas, the altitude of the water table in the vicinity of a stream generally is higher than the altitude of the stream-water surface making possible the discharge of ground water into the stream. Small streams may have very little runoff because pervious sandy soil drains water rapidly and the channels of streams do not cut deep enough to intercept ground water (Thomson and Carter, 1955). Large streams in the upper Coastal Plain generally have uniform flow because of small runoff and high yields due to ground-water discharge (Thomson and Carter, 1955).

In the lower Coastal Plain, the relatively flat topography is dominated by estuaries and marshes. Local flow systems have less affect on stream conditions because of low relief and shallow ground-water hydraulic gradients from aquifers toward streams. Thomson and Carter (1955) described the lower Coastal Plain as having the least streamflow within Georgia because of high air temperatures and low flow-producing land characteristics, and because of high consumptive demands for water by the dense growth in the swamps. The terrain consists of wide and flat ridges separated by wide, swampy, and heavily wooded valleys (Thomson and Carter, 1955). Tidal effects and differences in runoff, due to soil type and vegetative cover, account for the variation in baseflow between upper and lower Coastal Plain (Carter and Putnam, 1977).

\section{Climate}

The study area has a mild climate with warm, humid summers and mild winters. Mean annual temperature ranges from about 63 degrees Fahrenheit $\left({ }^{\circ} \mathrm{F}\right)$ in Burke County, Ga., to about $70^{\circ} \mathrm{F}$ in Glynn County, Ga., for the period 1971-2000 (National Oceanic and Atmospheric Administration, 2002).

Precipitation data were evaluated from 10 NWS stations in Georgia and 1 in South Carolina. Of these stations, six were selected to determine long-term trends that could affect ground-water recharge and associated water-level fluctuations. The Georgia stations are located at Alma, Brooklet, Brunswick, Dublin, Folkston, Homerville, Jesup, Savannah, Tifton, and Waynesboro; the South Carolina station is located at Bamberg (figs. 1 and 5). Mean annual precipitation, based on the period 1971-2000 ranges from about $47 \mathrm{in} / \mathrm{yr}$ in Waynesboro, Ga., to about $53 \mathrm{in} / \mathrm{yr}$ in Folkston, Ga. (fig. 5). Rainfall is not evenly distributed throughout the year. The maximum rainfall generally occurs during the summer months of June, July, and August (fig. 6). Estimated evapotranspiration ranges from $31 \mathrm{in} / \mathrm{yr}$ in the northern part of the study area to more than $40 \mathrm{in} / \mathrm{yr}$ in Charlton and Ware Counties, Ga., near the Okefenokee Swamp (Krause and Randolph, 1989). Rainfall as a source of recharge to aquifers is most important during the nongrowing season, generally October through March, when evapotranspiration is lowest.

\section{Surface Water}

The study area is drained by several major river systems: SSO River Basin, SAS River Basin, and Suwannee River Basin (fig. 1; table 1). The largest river basins are the SAS, with a drainage area of about $14,142 \mathrm{mi}^{2}$; and the SSO, with a drainage area of about 10,734 $\mathrm{mi}^{2}$. The Suwannee River has a drainage area of about $6,400 \mathrm{mi}^{2}$. With the exception of the Suwannee River, which drains to the Gulf of Mexico, each of the rivers discharges into the Atlantic Ocean.

Surface-water discharge in the study area primarily is affected by precipitation, baseflow, evapotranspiration, and pumpage. Four power plants use surface water within the SSO River Basin, and one power plant within the SAS River Basin. Surface water accounts for about 75 percent of total water usage in the Georgia Coastal Plain (Fanning, 1999). In the Coastal Plain, mean annual runoff ranges between 24 and 31 percent of total rainfall (Carter and Stiles, 1983). In the study area, runoff during the period 1941-70 was about $14 \mathrm{in} / \mathrm{yr}$ in the upper Coastal Plain, and about $12 \mathrm{in} / \mathrm{yr}$ in the lower Coastal Plain (Carter and Stiles, 1983) (fig. 7). 


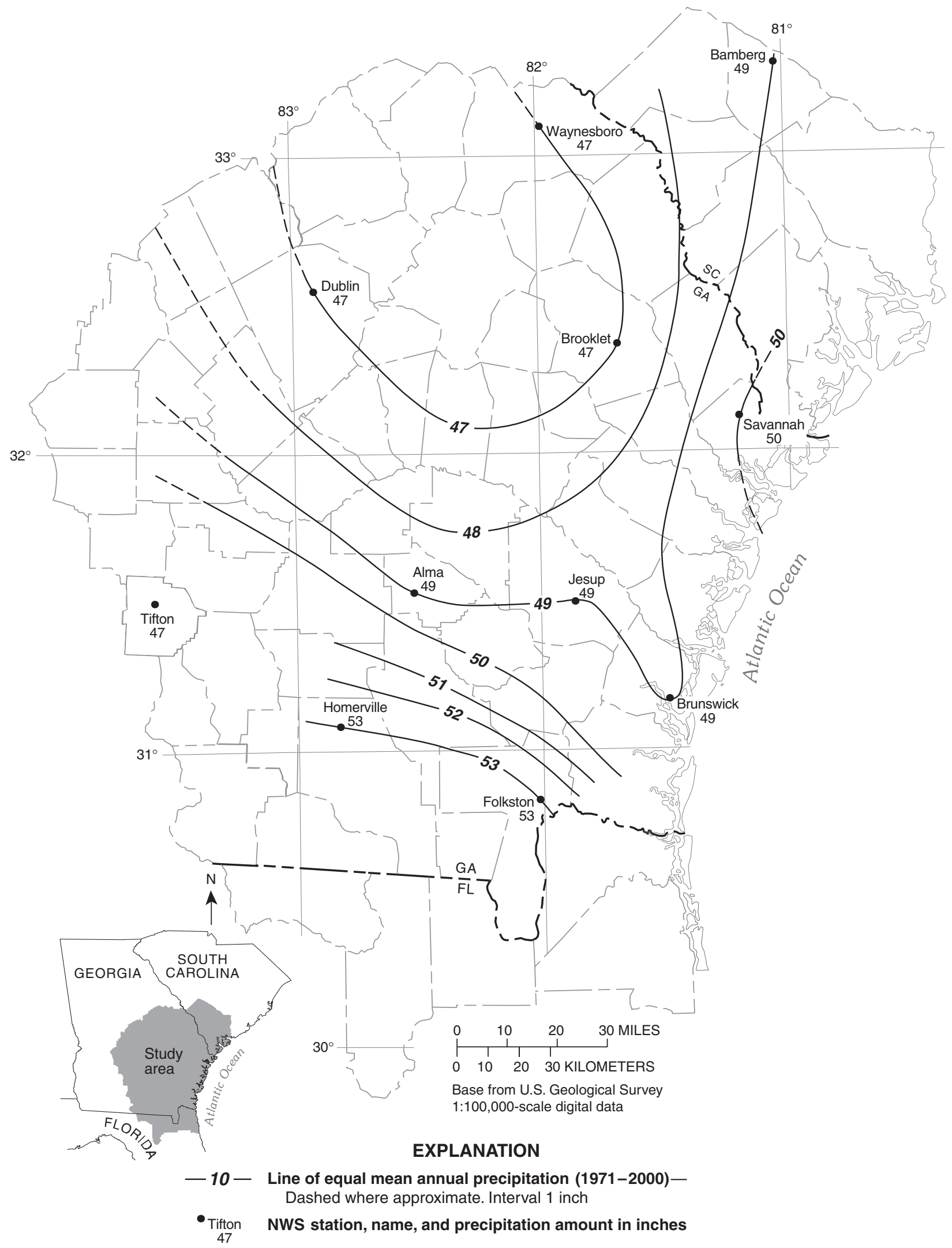

Figure 5. Mean annual precipitation for selected National Weather Service (NWS) stations in the Coastal Plain of Georgia and South Carolina, 1971-2000. 

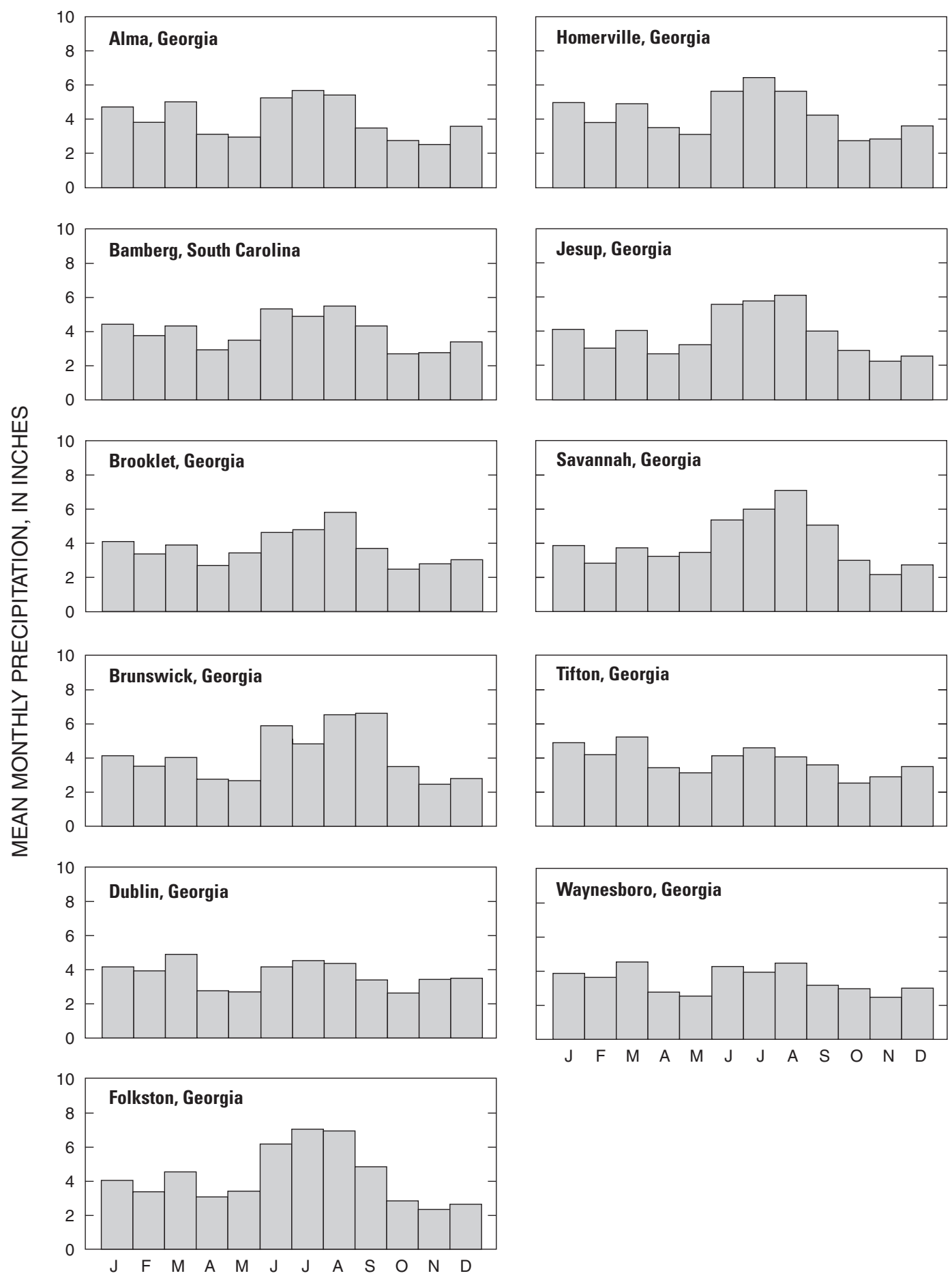

Figure 6. Mean monthly precipitation at selected National Weather Service stations in the Coastal Plain area of Georgia and South Carolina, 1971-2001. 


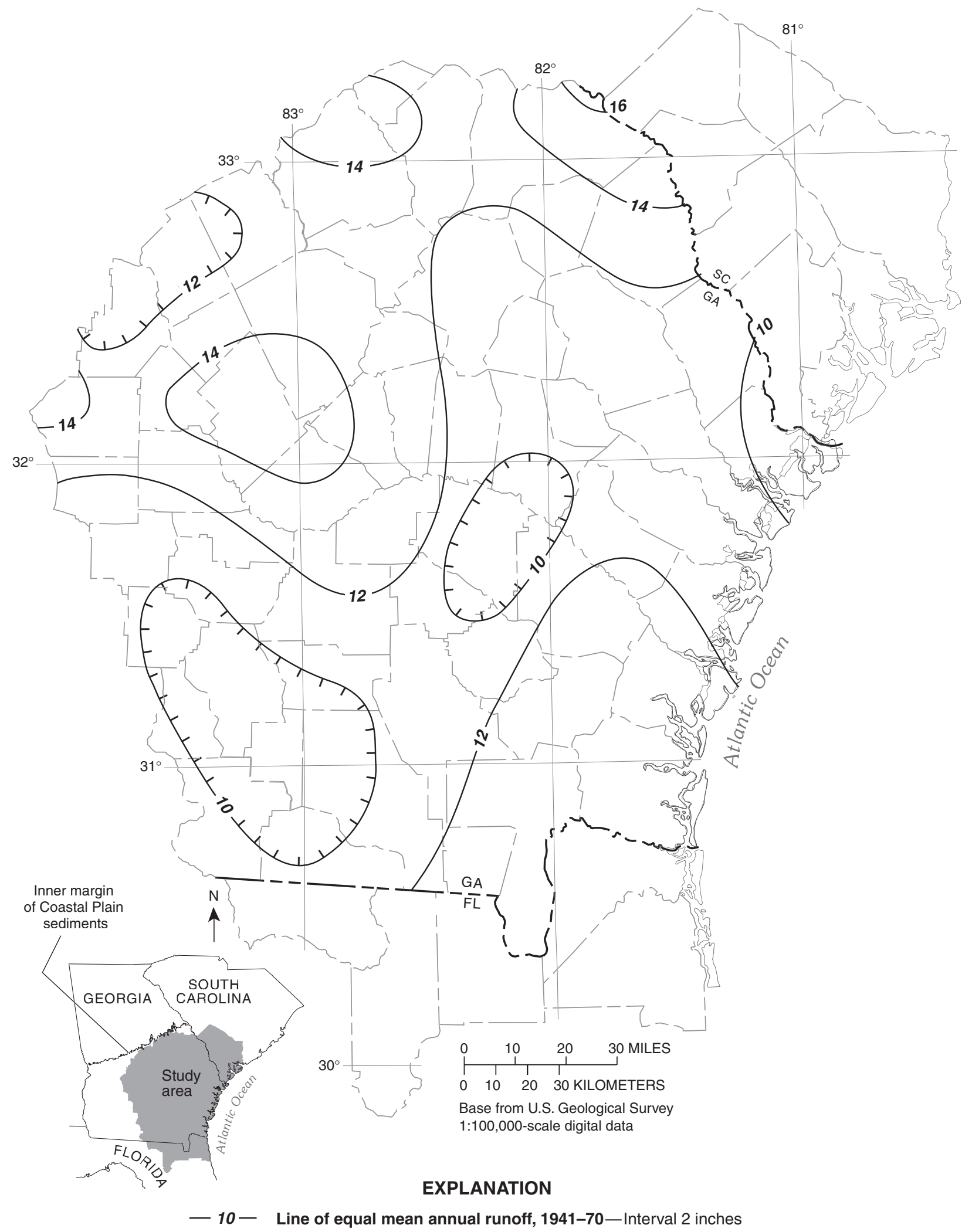

Figure 7. Mean annual runoff for the Coastal Plain of Georgia, 1941-70. 
A. Brier Creek

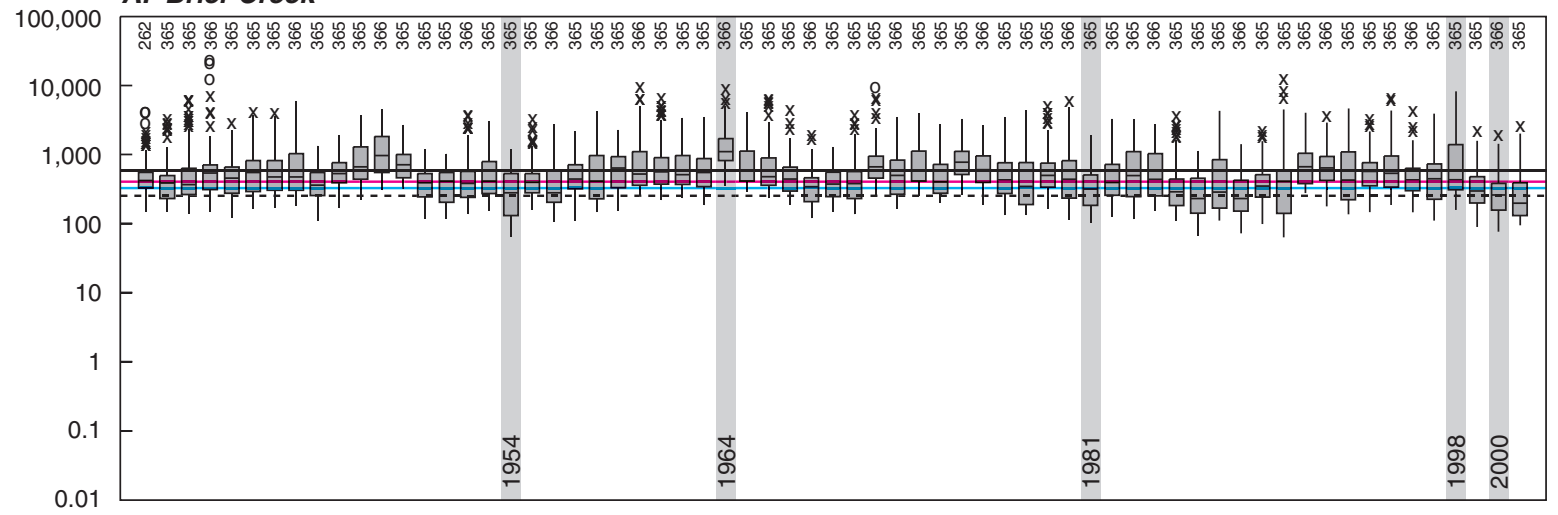

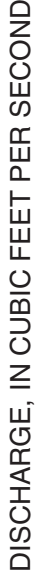

100,000 B. Canoochee River 10,000

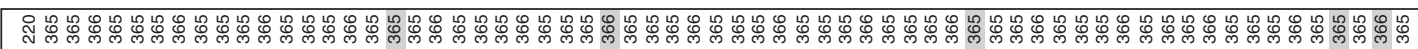

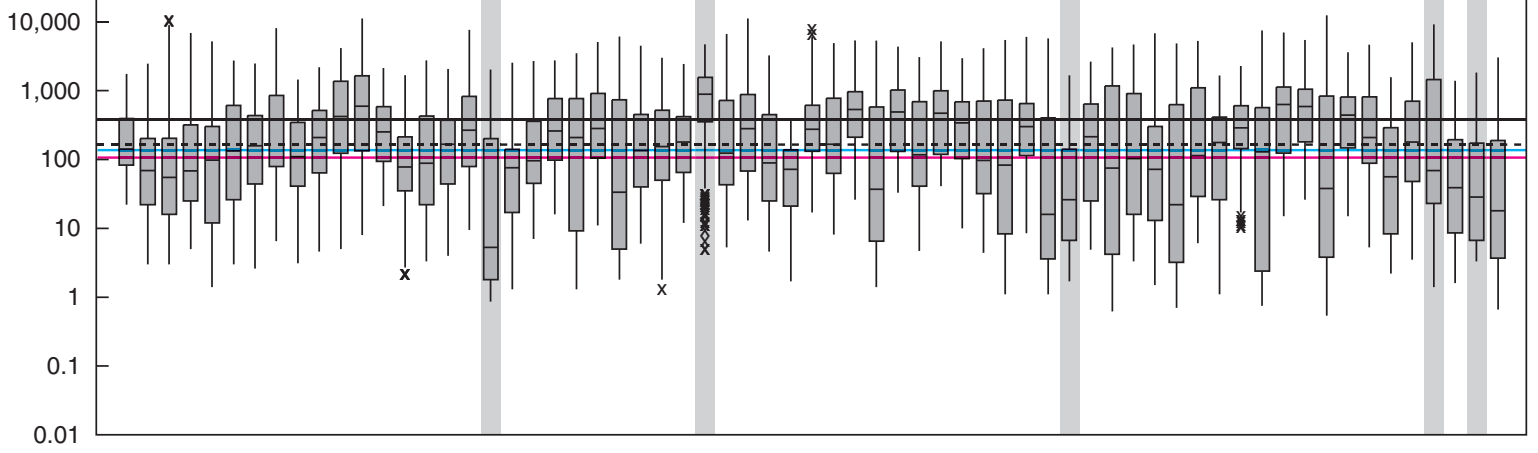

C. Little Satilla River

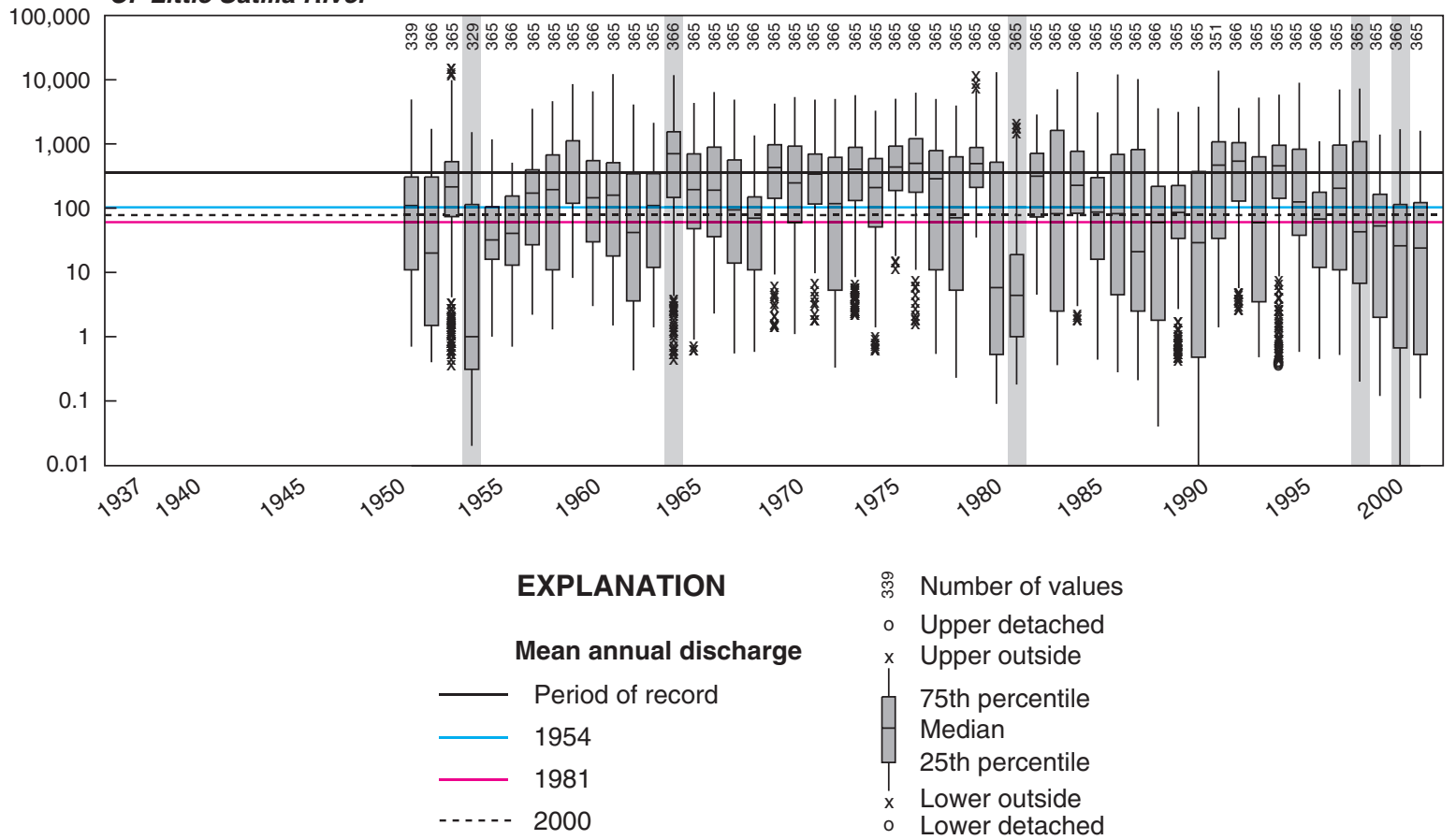

Figure 8. Distribution of daily streamflow for $(A)$ Brier Creek (station 02198000) near Millhaven, Georgia; (B) Canoochee River (station 02203000) near Claxton, Georgia; and (C) Little Satilla River (station 02227500) near Offerman, Georgia, for the period of record. 
Streamflow characteristics are summarized in boxplots showing streamflow duration for each year during the period of record for selected stations in the study area (fig. 8). For three comparably sized basins, boxplots of daily streamflows were prepared for each year of the period of record. The boxplots depict the minimum, maximum, mean, and median daily discharge; and the 25 and 75 percentiles for each calendar year. The mean annual discharge was computed for the period of record and used as a reference for the drought-year streamflow. Brier Creek (station 02198000) in the SSO River Basin shows climatically driven rise and fall (cyclical) in streamflow throughout the period of record (fig. 8). The mean annual discharges indicate that the 2000 drought was the most severe followed by the 1954 and 1981 droughts, respectively. The Canoochee River (station 02203000) in the SSO River Basin also shows a climatically driven cyclical trend in discharge throughout the period of record. At this station, the 1981 drought was the most severe followed by the 1954 and 2000 droughts, respectively (fig. 8). The Little Satilla River (station 02227500) is less cyclical than the previous two stations, with the 1981 drought the most severe followed by the 2000 and 1954 droughts, respectively (fig. 8). Pronounced dry years are evident at each site during 1954, 2000, and 2001, and wet periods are evident during 1964 and 1998. In any given year, streamflow generally is highest during the winter-spring and lowest during the summer-fall when evapotranspiration is highest (fig. 9).

\section{Ground Water}

Sediments and rock form a series of aquifers and confining units that have variable geologic and hydrologic properties in the upper and lower Coastal Plain (fig. 2). The following sections describe the various hydrogeologic units and waterlevel fluctuations and trends-long-term incline or decline in overall water levels - in major aquifer units in the upper and lower Coastal Plain.

\section{Hydrogeologic Units}

Principal water-bearing units in the upper Coastal Plain are, in order of increasing depth, the Upper Three Runs aquifer, Gordon aquifer, and Upper Dublin aquifer (fig. 2). In the lower Coastal Plain, the principal water-bearing units are in descending order, the surficial aquifer system, Brunswick aquifer system, and Floridan aquifer system (fig. 2). Low-permeability clayey confining units separate these waterbearing units.

\section{Upper Coastal Plain}

The Upper Three Runs aquifer, formerly referred to as the Jacksonian aquifer (Vincent, 1982), consists of quartz, calcareous sand, and limestone of the Barnwell Group and undifferentiated post-Miocene deposits (fig. 2) (Falls and others, 1997; Huddlestun and Hetrick, 1986). The sands are
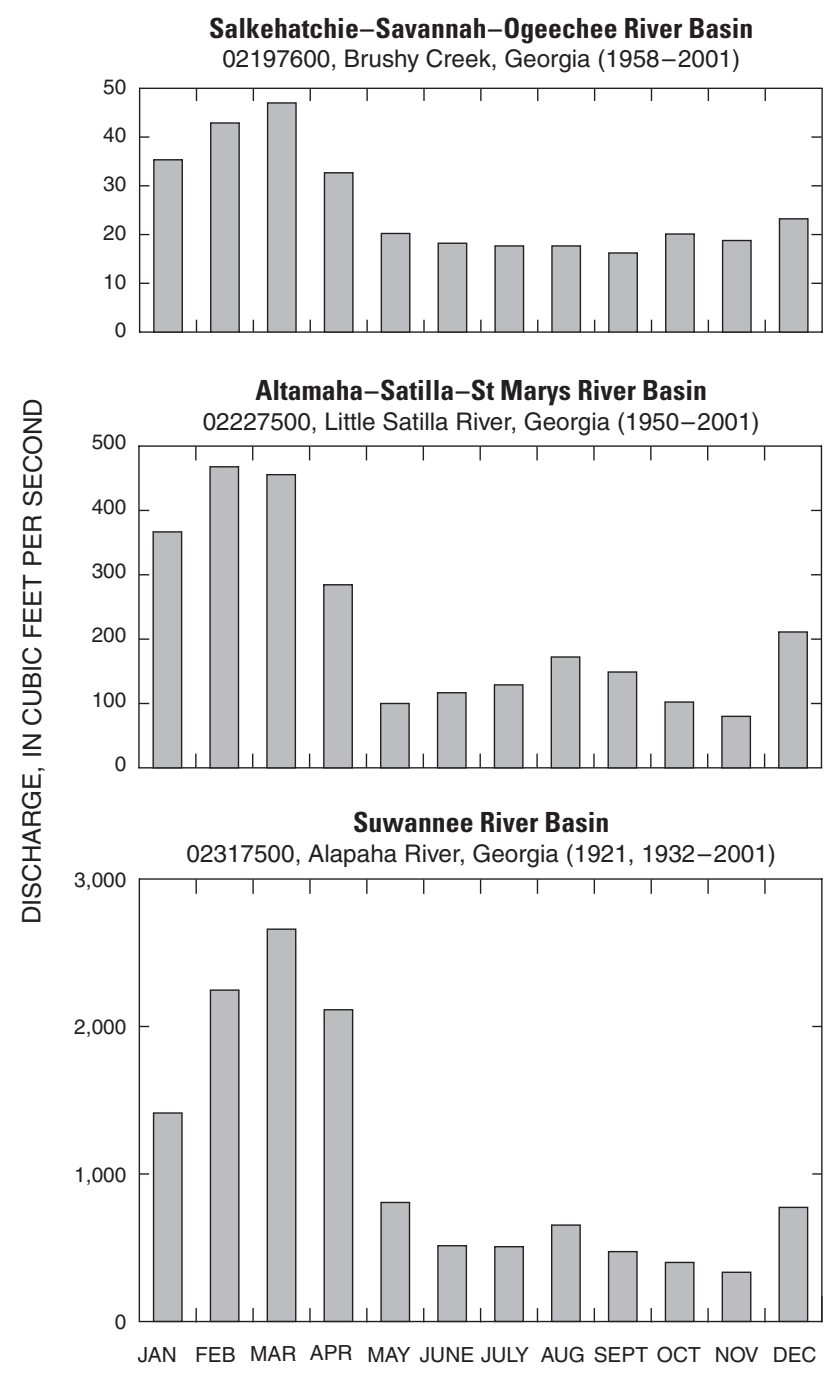

Figure 9. Mean monthly streamflow at a selected streamflow gaging station within the SalkehatchieSavannah-Ogeechee, Altamaha-Satilla-St Marys, and Suwannee River Basins for the periods of record.

highly permeable; however, low-permeability clay beds and lenses are present at the top of the aquifer (Huddlestun and Summerour, 1996). The Upper Three Runs aquifer is hydrogeologically equivalent to the Upper Floridan aquifer in the lower Coastal Plain.

The Gordon aquifer, underlying the Upper Three Runs aquifer, consists of sand and calcareous sand of the Congaree Formation (fig. 2) (Falls and others, 1997). The Gordon aquifer is the updip equivalent of the Lower Floridan aquifer in the lower Coastal Plain. The Gordon aquifer is underlain by a confining unit that consists of black laminated clay of the Ellenton Formation and moderately to poorly sorted, fine to very coarse sand of the Snapp Formation.

The Upper Dublin aquifer underlies the Gordon aquifer. The Upper Dublin aquifer consists of poorly to moderately sorted fine quartz sand with thin beds of clay of the Steel 
Creek Formation and Black Creek Group, undifferentiated (fig. 2). The Upper Dublin aquifer is hydrogeologically equivalent to the Fernandina permeable zone of the Lower Floridan aquifer in the lower Coastal Plain.

\section{Lower Coastal Plain}

In the lower Coastal Plain, the surficial aquifer system consists of interlayered sand, clay, and thin limestone beds of post-Miocene age (Clarke and others, 1990; Leeth, 1999). Generally, the surficial aquifer is under water-table conditions throughout the study area. Locally, however, the aquifer may be confined or semiconfined by dense phosphatic limestone or dolomite, and phosphatic silty clay of undifferentiated Miocene sediments (Leeth, 1999; Clarke, 2003). A confining unit that consists of clay, silt, phosphatic limestone or dolomite, and sand of Miocene age underlies the surficial aquifer (fig. 2). Sand and limestone within this unit have been identified as a source of water in parts of the coastal area. Clarke and others (1990) designated this unit as the upper and lower Brunswick aquifers.

The upper Brunswick aquifer consists of poorly sorted, fine to coarse, slightly phosphatic and dolomitic quartz sand of the Coosawhatchie and Marks Head Formations (fig. 2) (Randolph and others, 1991; Weems and Edwards, 2001). This aquifer is confined by upper and lower confining units of the Miocene Parachucla Formation. The upper Brunswick aquifer is present in the Brunswick area and generally is absent in the Savannah area.

The lower Brunswick aquifer consists of quartzose calcarenite to calcareous quartz sand of the Tiger Leap Formation (fig. 2) (Weems and Edwards, 2001). The Parachucla Formation in most of coastal Georgia overlies the Tiger Leap Formation. In the lower Coastal Plain, the lower Brunswick aquifer mostly is absent in the Savannah area and in Bulloch County because the permeable upper sand in Miocene sediments either has been eroded away or was never deposited (Clarke and others, 1990). At the base of the lower Brunswick aquifer is a confining unit consisting of Oligocene fossilerous limestone of the Lazaretto Creek Formation (Huddlestun, 1993). The surficial and Brunswick aquifer systems and Upper Floridan aquifer are hydrogeologically equivalent to the Upper Three Runs aquifer in the upper Coastal Plain.

The Upper Floridan aquifer supplies most of the drinking water obtained from ground water for coastal Georgia. In the lower Coastal Plain, this aquifer is largely carbonate, consisting of Eocene to Oligocene limestone and dolomite. The Oligocene Lazaretto Creek Formation overlies the Upper Floridan aquifer (Huddlestun, 1993). Units composing the Upper Floridan aquifer crop out at or near land surface in the upper Coastal Plain, where the aquifer is under confined to semiconfined conditions. The Upper Floridan aquifer is separated from the underlying Lower Floridan aquifer by a confining unit of dense, low-permeability, recrystallized Eocene limestone and dolomite. The confining unit has very low primary hydraulic conductivity; however, in the Brunswick area, joints and fractures produce zones of high secondary hydraulic conductivity (Krause and Randolph, 1989).

The Lower Floridan aquifer mostly consists of Eocene dolomitic limestone but locally may include Paleocene to Upper Cretaceous dolomitized limestone. This aquifer is confined throughout the coastal area and is subdivided into at least three permeable units in the Brunswick area-the brackish-water zone, deep freshwater zone (Gregg and Zimmerman, 1974), and Fernandina permeable zone (Krause and Randolph, 1989). The Fernandina permeable zone is highly permeable and cavernous, and contains high salinity water that may be the source of saltwater contamination in the Brunswick area. The Fernandina permeable zone consists of Paleocene to Upper Cretaceous pelletal, recrystallized limestone and finely crystallized dolomite.

\section{Ground-Water Levels}

Ground-water level fluctuations reflect changes in recharge to and discharge from an aquifer. Recharge varies in response to precipitation, and discharge varies in response to leakage to adjacent aquifers, withdrawal from wells, and evapotranspiration from shallow unconfined aquifers.

In the surficial aquifer, water levels show a pronounced response to climatic effects throughout the study area. Where climatic effects dominate, water levels generally are highest in the winter and early spring when precipitation is greatest and evapotranspiration is least; water levels are lowest during the summer and fall when precipitation is least and evapotranspiration is highest. These fluctuations are illustrated on the hydrograph for well 35P094 near Savannah (fig. 10). The 15 -ft-deep well is completed in the surficial aquifer and shows pronounced water-level rise in response to precipitation, followed by a gradual decline that corresponds to discharge from the aquifer.

In the lower Coastal Plain, with the exception of the unconfined part of the surficial aquifer system, aquifers are deeply buried and confined. In these areas, climatic effects are greatly diminished, and fluctuations largely are because of changes in ground-water pumping. These fluctuations are illustrated for well 36Q008 near Savannah (fig. 10). The 406-ft-deep well is completed in the Upper Floridan aquifer and shows a pronounced response to changes in local and regional pumping, but little response to changes in precipitation. Water-level response to pumping in adjacent aquifers may be similar due to interaquifer leakage. This response in adjacent aquifers is most pronounced in the upper Coastal Plain and results from greater aquifer interconnection because of the thin, sandy, and discontinuous nature of the confining units in this area. In addition, ground-water pumping in the lower Coastal Plain may have produced hydraulic gradients that resulted in increased aquifer leakage and similar waterlevel responses. Such similarities are indicated on the hydrographs for wells completed in the surficial, upper Brunswick, and Upper Floridan aquifers (32L017, 32L016, and 32L015, respectively) at Gardi, Wayne County, Georgia (fig. 11). 

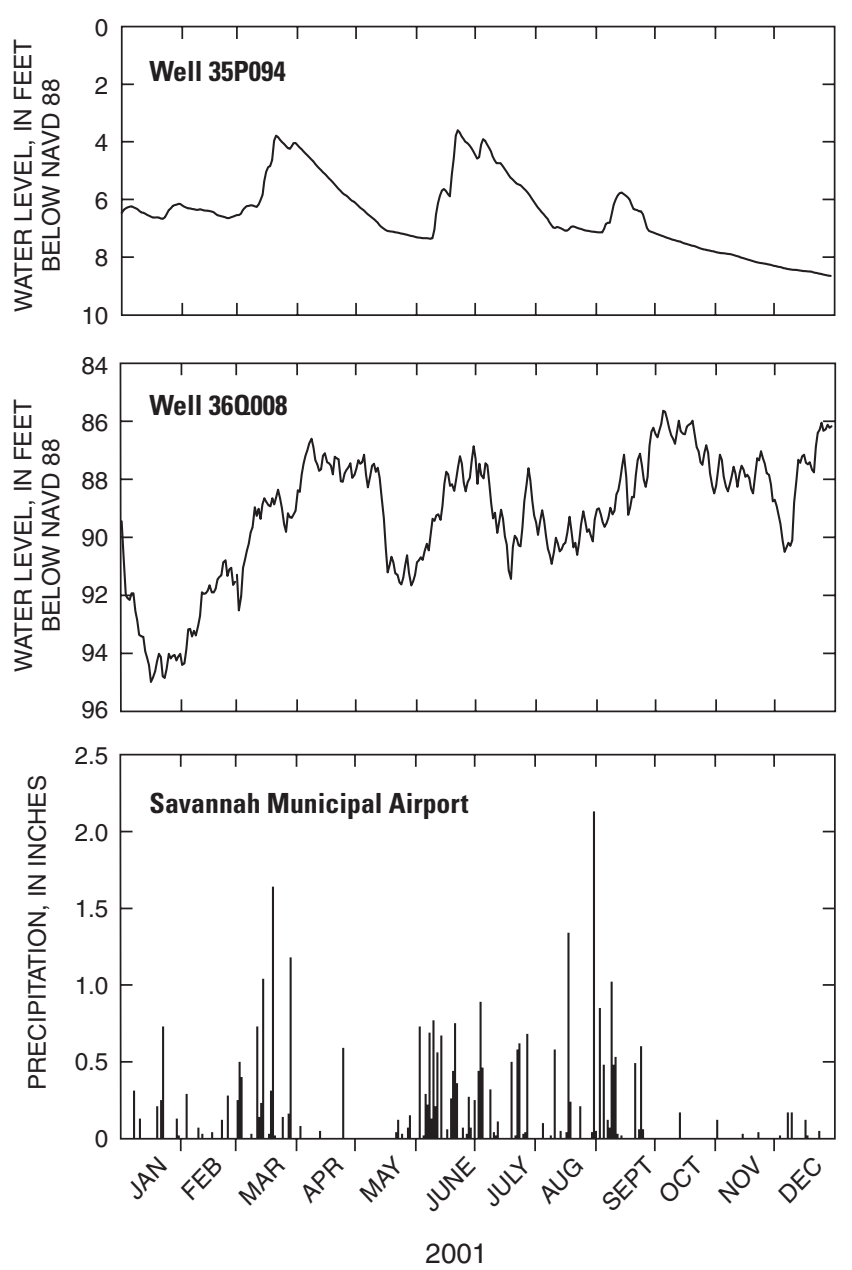

Figure 10. Daily water-level measurements in wells 35P094 and 360008, Chatham County; and daily rainfall at National Weather Service station, Savannah Municipal Airport, Chatham County, Georgia, 2001.

\section{Long-Term Fluctuations and Trends}

Long-term fluctuations in precipitation, ground-water levels, and streamflow show the effects of natural and anthropogenic stresses on the stream-aquifer flow system. Precipitation changes are reflected in streamflow and in ground-water levels of aquifers that are unconfined or semiconfined. When ground-water levels are high from natural recharge (precipitation), ground-water contribution to streamflow is correspondingly high. Conversely, when ground-water levels are low because of lack of recharge or increased pumping, groundwater contribution to streamflow is correspondingly low. Fluctuations and trends are shown on selected graphs of cumulative departure from normal precipitation, groundwater levels, and streamflow in the SSO, SAS, and Suwannee River Basins (figs. 12-14, respectively). Normal precipitation for a given month is defined as the average of total monthly precipitation during a specified 30-year period; for this report, the period 1971-2000 was used to determine normal precipitation for computation of cumulative departure.

Upward or positive slopes on the graph indicate periods of above-normal precipitation; downward or negative slopes on the graph indicate periods of below-normal precipitation; no slope indicates periods of normal precipitation. Trend is the overall slope over a period of time. A short-term trend covers a period of 5 years or less; a long-term trend covers a period greater than 5 years. An above-normal trend means that the slopes over a period of time are positive or upward; whereas a below-normal trend means that the slopes over a period of time are negative or downward. Fluctuations and trends in the major river basin groupings are plotted for the period 1971-2001.

\section{Salkehatchie-Savannah-Ogeechee River Basin}

In the upper part of the SSO River Basin, precipitation trends are illustrated on the cumulative departure graph for the Waynesboro, Ga., station (fig. 12). In general, there were several short-term trends of above- and below-normal precipitation during 1971-84 followed by a long-term trend of below-normal precipitation during 1984-91. A longterm trend of above-normal precipitation is observed during 1992-98 with intermittent short-term trends of below-normal precipitation. During 1999-2001, there was a short-term trend of below-normal precipitation in Waynesboro, Ga., reflecting the 2000 drought. By the end of the study period, the overall cumulative departure was +19.47 inches at Waynesboro.

Streamflow in the upper part of the SSO River Basin is shown on bar graphs of mean annual discharge for Brier Creek (station 02198000) (fig. 12). Generally, about half of the streamflow was at or above the 31-year mean for this station. Changes in streamflow correspond to above- and belownormal periods of precipitation for the area. Two of the three severe drought periods - 1981 and 2000 - are more than $200 \mathrm{ft}^{3} / \mathrm{s}$ below the 31-year mean of about $598 \mathrm{ft}^{3} / \mathrm{s}$.

Ground-water levels in the upper part of the SSO River basin are shown for well 32R003, Bulloch County (fig. 12), completed in the surficial aquifer to a depth of $155 \mathrm{ft}$. Data are insufficient to recognize a trend in the water level; however, well 32R003 taps a deeper part of the surficial aquifer where semiconfined conditions occur as a result of a clay confining unit.

In the lower part of the SSO River Basin, precipitation trends are illustrated on the cumulative departure from normal precipitation graph for the Savannah, Ga., station (fig. 12). In general, there was a long-term trend of below-normal precipitation during 1973-90 with intermittent short-term trends of above-normal precipitation. There was a long-term trend of generally above-normal precipitation during 1990-95, followed by a long-term trend of generally below-normal precipitation during 1996-2001. Effects of drought are evidenced by a short-term trend of below-normal precipitation during 1999-2001. By the end of the study period, the overall cumulative departure was -13.26 inches at Savannah. 


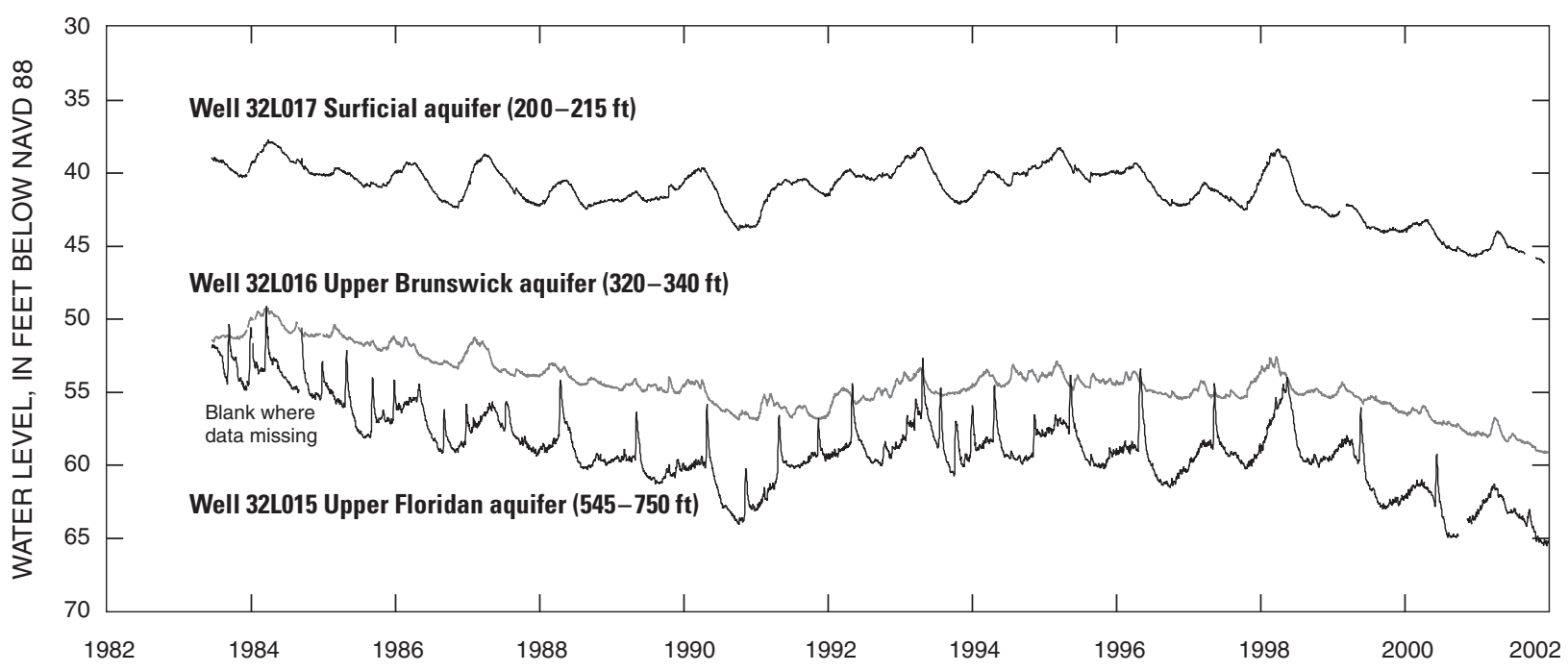

Figure 11. Daily mean water levels in the surficial, upper Brunswick, and Upper Floridan aquifers at the Gardi site, Wayne County, Georgia, 1983-2001.

Streamflow in the lower part of the SSO River basin is shown on bar graphs for Canoochee River (station 02203000) (fig. 12). Generally, about half of the streamflow was at or above the 31-year mean for this station. Changes in streamflow correspond to above- and below-normal periods of precipitation for the area. Two of the three severe drought periods - 1981 and 2000 - are more than $350 \mathrm{ft}^{3} / \mathrm{s}$ below the 31 -year mean of about $484 \mathrm{ft}^{3} / \mathrm{s}$. Drought conditions had a greater effect on streamflow in the lower part of the basin than in the upper part of the basin, probably because of interconnectivity with the aquifer.

Ground-water levels in the lower part of the SSO River Basin are shown for well 35P094, Chatham County, completed in the surficial aquifer to a depth of $15 \mathrm{ft}$ (fig. 12). No long-term trend is evident, and water levels show a pronounced response to climatic effects. Recharge by precipitation is reflected by a sharp rise in the water level followed by a gradual decline that represents evapotranspiration and recharge of water into the aquifer.

\section{Altamaha-Satilla-St Marys River Basin}

In the upper part of the SAS River Basin, precipitation trends are illustrated on the cumulative departure graph for the Dublin station (fig. 13). There was a long-term trend of at- or below-normal precipitation during 1975-91, followed by a long-term trend of above-normal precipitation during 1992-98, followed by another short-term trend of belownormal precipitation during 1999-2001, reflecting effects of drought. By the end of the study period, the overall cumulative departure was -17.14 inches at Dublin.

Streamflow in the upper part of the SAS River Basin is shown on bar graphs for the Oconee River (station 02223500) (fig. 13). Streamflow appears to fluctuate in a similar manner as precipitation, with low streamflow occurring during below-normal precipitation years and high streamflow occurring during above-normal precipitation years. During two-thirds of the study period, streamflow was at or above the 31-year mean. During the drought years of 1981 and 2000, streamflow was about 2,000 ft $3 / \mathrm{s}$ below the 31-year mean of about $4,393 \mathrm{ft}^{3} / \mathrm{s}$.

Ground-water levels in the upper part of the SAS River Basin are shown for well 21T001 (fig. 13) Laurens County, completed in the Upper Floridan aquifer to a depth of $123 \mathrm{ft}$. The hydrograph shows seasonal fluctuations of the water level in response to precipitation. Starting in 1999, the hydrograph slopes downward slightly, indicating the effects of the 2000 drought.

In the lower part of the SAS River Basin, precipitation trends are illustrated on the cumulative departure graph for the Jesup site (fig. 13). Generally, there were two long-term trends of at- or above-normal precipitation during 1976-87, and 1989-95. Following these trends was a short-term trend of generally below-normal precipitation during 1998-2001. By the end of the study period, the overall cumulative departure was -12.39 inches.

Streamflow in the lower part of the SAS River Basin is shown on bar graphs for the Little Satilla River (station 02227500) (fig. 13). Streamflow appears to fluctuate in a similar manner as precipitation, with low streamflow occurring during below-normal precipitation years and high streamflow occurring during above-normal precipitation years. More than half of the mean annual streamflow was at or above the 31-year mean for the station. During the drought years of 1981 and 2000, streamflow was about $500 \mathrm{ft}^{3} / \mathrm{s}$ below the 31 -year mean of about $542 \mathrm{ft}^{3} / \mathrm{s}$. 

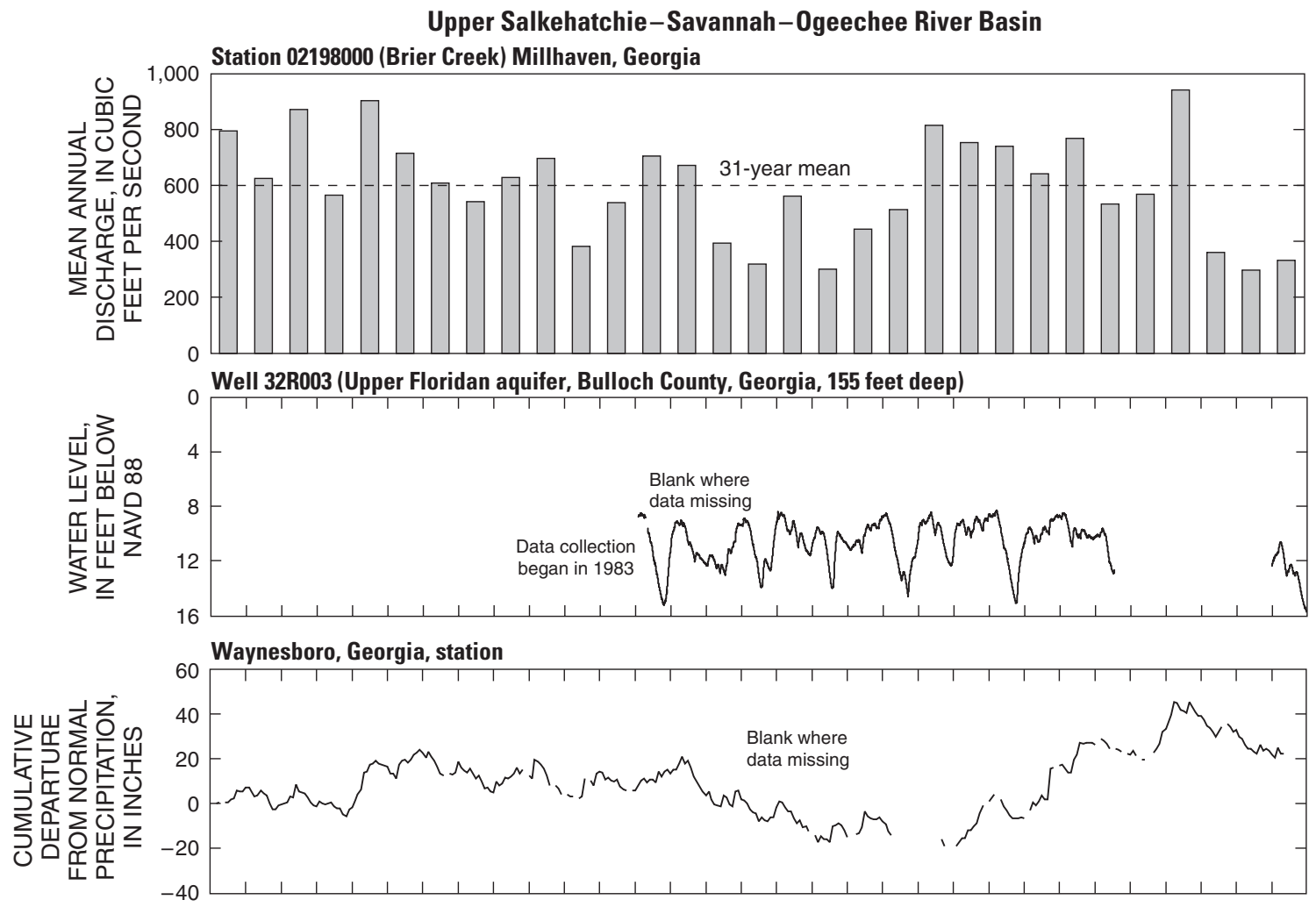

Lower Salkehatchie-Savannah-Ogeechee River Basin
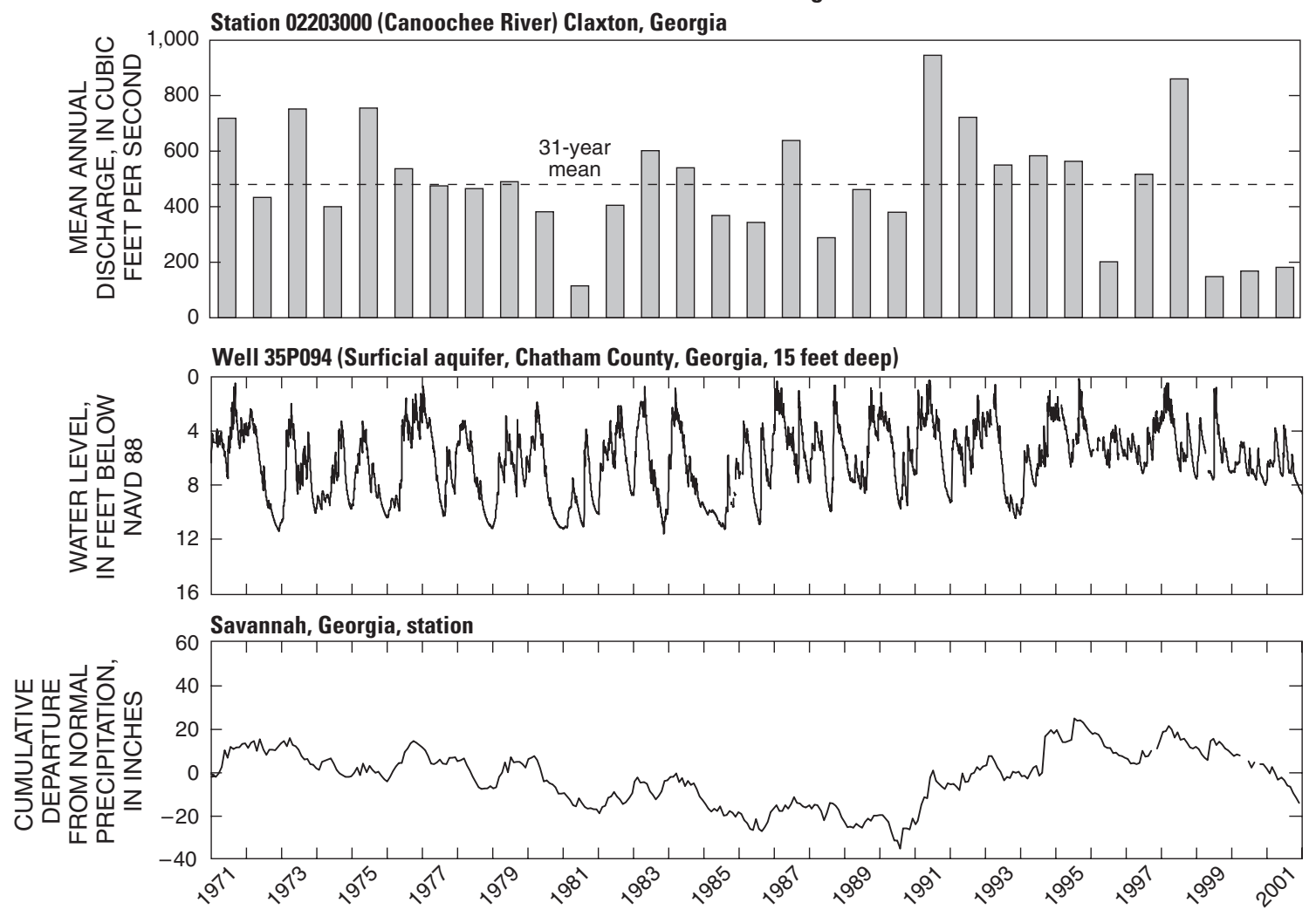

Figure 12. Mean annual stream discharge, daily mean ground-water level, and cumulative departure from normal precipitation for the upper and lower parts of SalkehatchieSavannah-Ogeechee River Basin, Georgia and South Carolina, 1971-2001. 

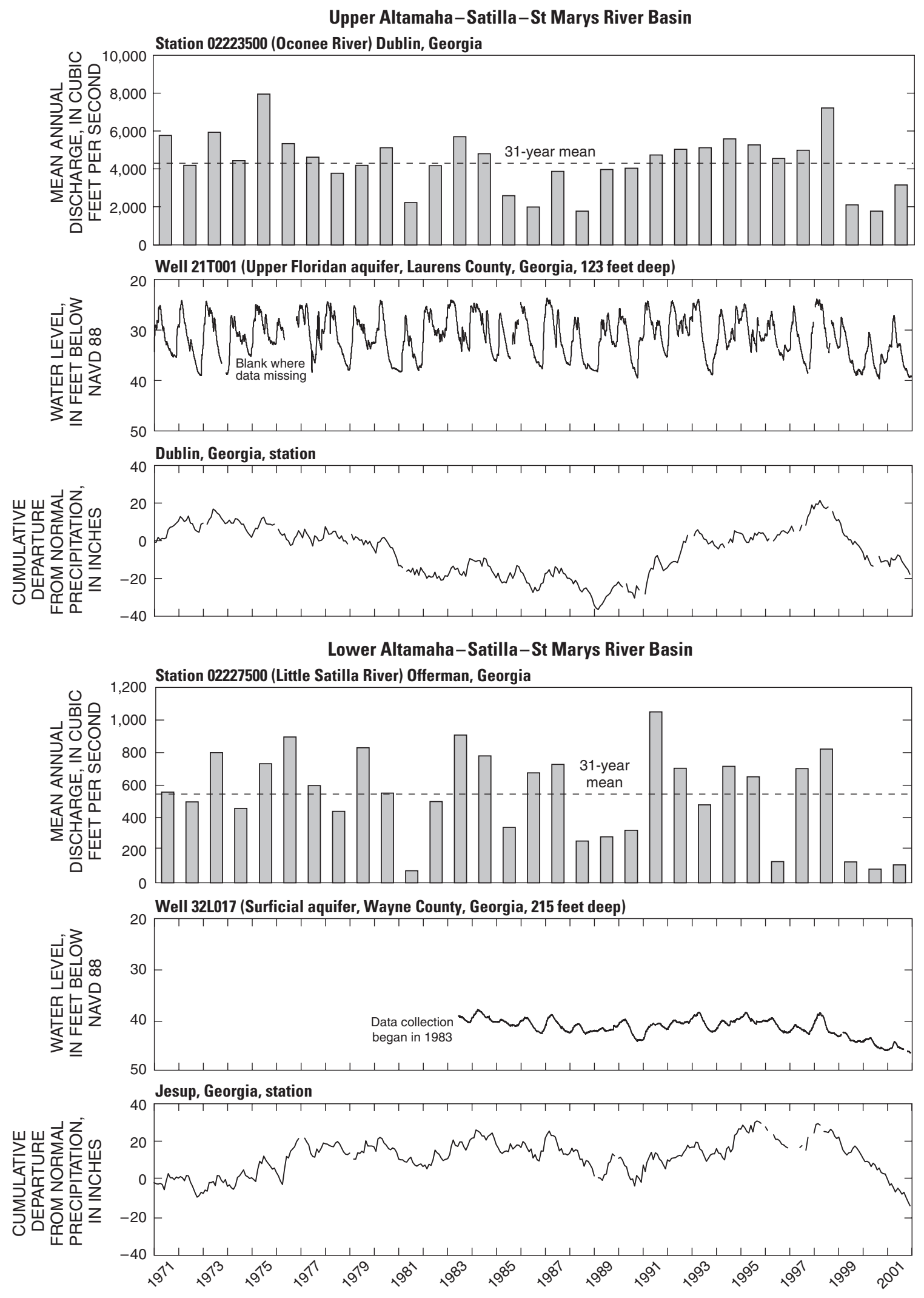

Figure 13. Mean annual stream discharge, daily mean ground-water level, and cumulative departure from normal precipitation for the upper and lower parts of the Altamaha-SatillaSt Marys River Basin, Georgia, 1971-2001. 
Ground-water levels in the lower part of the SAS River Basin are shown for well 32L017, Wayne County, completed in the surficial aquifer to a depth of $215 \mathrm{ft}$. In this area, the water level of the surficial aquifer is influenced largely by ground-water pumping and, to a lesser extent, changes in recharge because of the depth of the aquifer. Water levels in the well declined about $6 \mathrm{ft}$ during 1983-2001, with the most rapid decline beginning in 1999 as a result of the 2000 drought.

\section{Suwannee River Basin}

In the upper part of the Suwannee River Basin, precipitation trends are illustrated on the cumulative departure graph for the Tifton station (fig. 14). In general, there was a longterm trend of above-normal precipitation during 1971-88, followed by a long-term trend of below-normal precipitation during 1989-2001. By the end of the study period, the overall cumulative departure was -1.9 inches at Tifton.

Streamflow in the upper part of the Suwannee River Basin is shown on bar graphs for Alapaha River (station 02317500) (fig. 14). Streamflow generally responds to changes in precipitation, with low flow occurring during below-normal periods, such as 1999-2001, and high flow occurring during above-normal periods, such as 1983-84. Less than half of the mean annual streamflows are at or above the 31-year mean for the period. During the drought years of 1981 and 2000, streamflow was more than $700 \mathrm{ft}^{3} / \mathrm{s}$ below the 31-year mean.

Ground-water levels in the upper part of the Suwannee River Basin are shown for well 18K049, Tift County, completed in the Upper Floridan aquifer to a depth of $620 \mathrm{ft}$ (fig. 14). Water levels in this well are influenced mostly by changes in pumping. The general water-level trend in this well is an approximate decline of $35 \mathrm{ft}$ from 1978, when data collection began, to 2001 .

In the lower part of the Suwannee River Basin, precipitation trends are illustrated on the cumulative departure graphs for the Homerville station (fig. 14). Generally, there were long-term trends of above-normal precipitation during 1971-77 and 1991-98, with a long-term trend of below-normal precipitation during 1978-83, and a short-term trend of below-normal precipitation during 1999-2001. By the end of the study period, the overall cumulative departure was -9.44 inches at Homerville.

Streamflow in the lower part of the Suwannee River Basin is shown on bar graphs for Suwannee River (station 02314500) (fig. 14). Streamflow generally follows precipitation patterns, with pronounced declines in streamflow during below-normal precipitation periods. About half of the mean annual streamflow was at or above the 31-year mean for the period 1971-2001. During the drought years of 1981 and 2000, streamflow was more than $800 \mathrm{ft}^{3} / \mathrm{s}$ below the 31 -year mean of about $941 \mathrm{ft}^{3} / \mathrm{s}$.
Ground-water levels in the lower part of the Suwannee River Basin are shown for well 19E009, Lowndes County (fig. 4), completed in the Upper Floridan aquifer to a depth of $342 \mathrm{ft}$. Both pumping and recharge influence water levels in this well. Although the well is deep, it is located in an area of karst topography where there is interconnection between streams and the Upper Floridan aquifer. Water levels in the well generally followed precipitation trends during 1971-2001.

\section{Ground-Water Contribution to Streamflow}

The degree of aquifer interconnection with streams varies in the upper and lower Coastal Plain. In general, relief is greater and local flow occurs more in the upper Coastal Plain. In this area, the Upper Floridan and equivalent aquifers are unconfined or semiconfined and are incised by streams flowing through the area. In the lower Coastal Plain, the Upper Floridan aquifer is deeply buried and confined.

The interconnection between ground water and streams is illustrated on a map showing the potentiometric surface of the Upper Floridan aquifer for May 1998 (fig. 15). In the upper Coastal Plain, aquifer interconnection with streams is indicated by steep hydraulic gradients toward streams and potentiometric contours that cross in a "V" pattern upstream, indicating ground-water flow toward the stream. In the lower Coastal Plain, the aquifer is more deeply buried and is not incised. Here, potentiometric contours indicate little connection between the aquifer and overlying streams. An exception is in the karstic Valdosta area, where the aquifer is interconnected with streams.

Streamflow composes two major components - surface runoff and baseflow. On a typical hydrograph, peaks indicate rapid response to precipitation and represent the runoff component of a hydrograph. The slope of the streamflow recession indicates ground-water discharge to streams and represents the baseflow component of a hydrograph.

In relation to the conceptual model (fig. 4), baseflow in streams comprises contributions from the local, intermediate, and regional ground-water flow systems. Because local flow systems are most affected by rainfall during periods of extended drought, streamflow is assumed to be sustained entirely by baseflow.

Ground-water contribution to streamflow (baseflow) was estimated by using three methods. Hydrograph-separation analysis was used to estimate baseflow based on data from eight continuous-record stations. Field measurements of drought discharge from headwater to an adjacent streamflow gaging station and between two adjacent stations were used to estimate the minimum ground-water contribution to streamflow. Linear-regression analysis of streamflow duration and mean annual baseflow was performed to estimate the percentile of streamflow that most closely represents baseflow. 

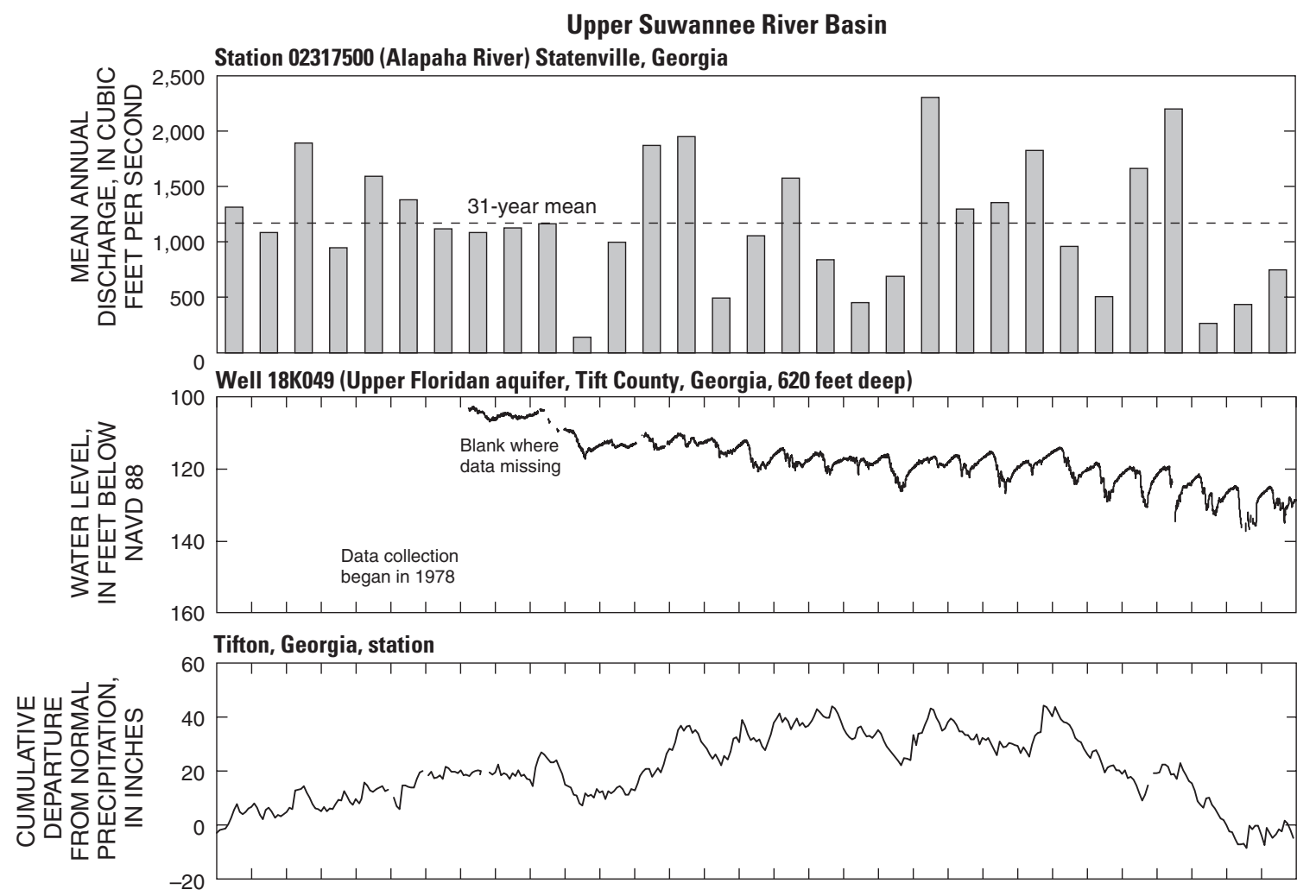

Lower Suwannee River Basin

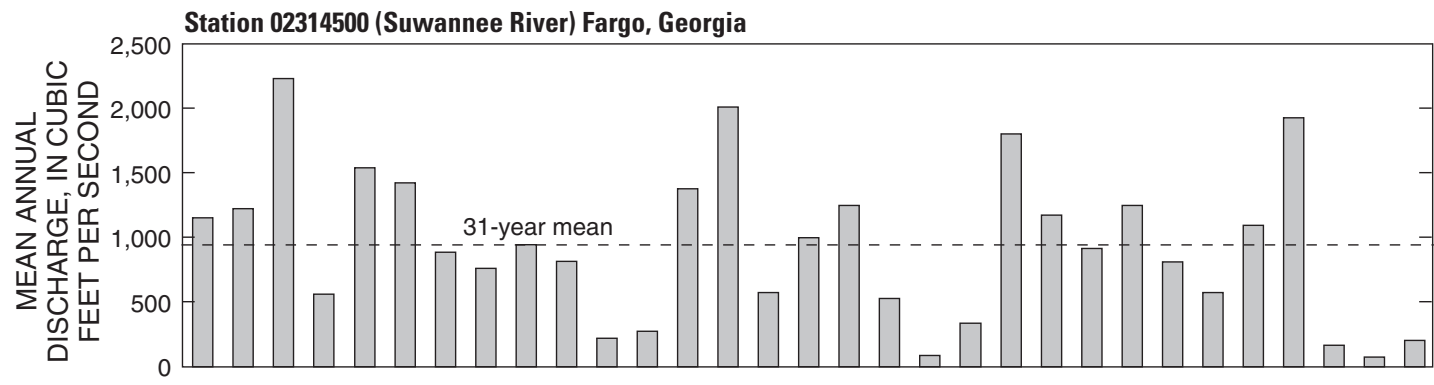

Well 19E009 (Upper Floridan aquifer, Lowndes County, Georgia, 342 feet deep)
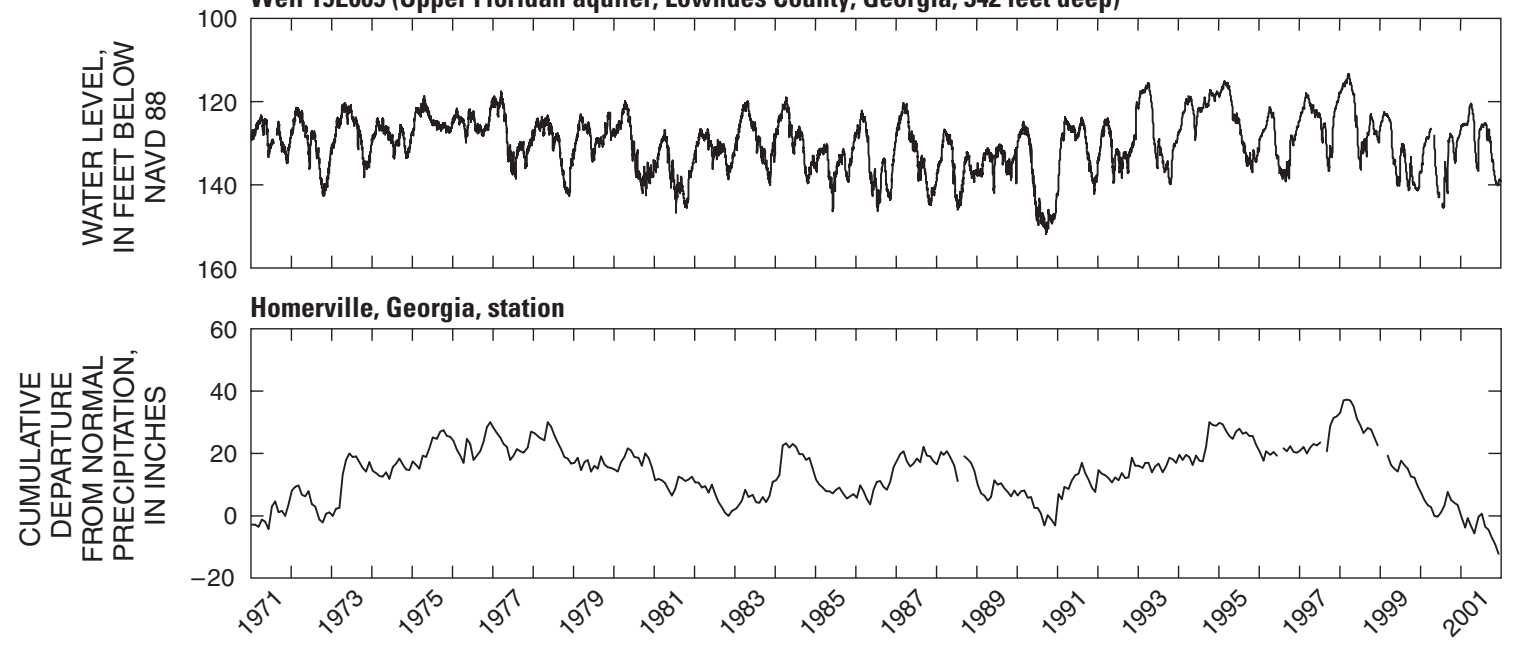

Figure 14. Mean annual stream discharge, daily mean ground-water level, and cumulative departure from normal precipitation for the upper and lower parts of the Suwannee River Basin, Georgia, 1971-2001. 


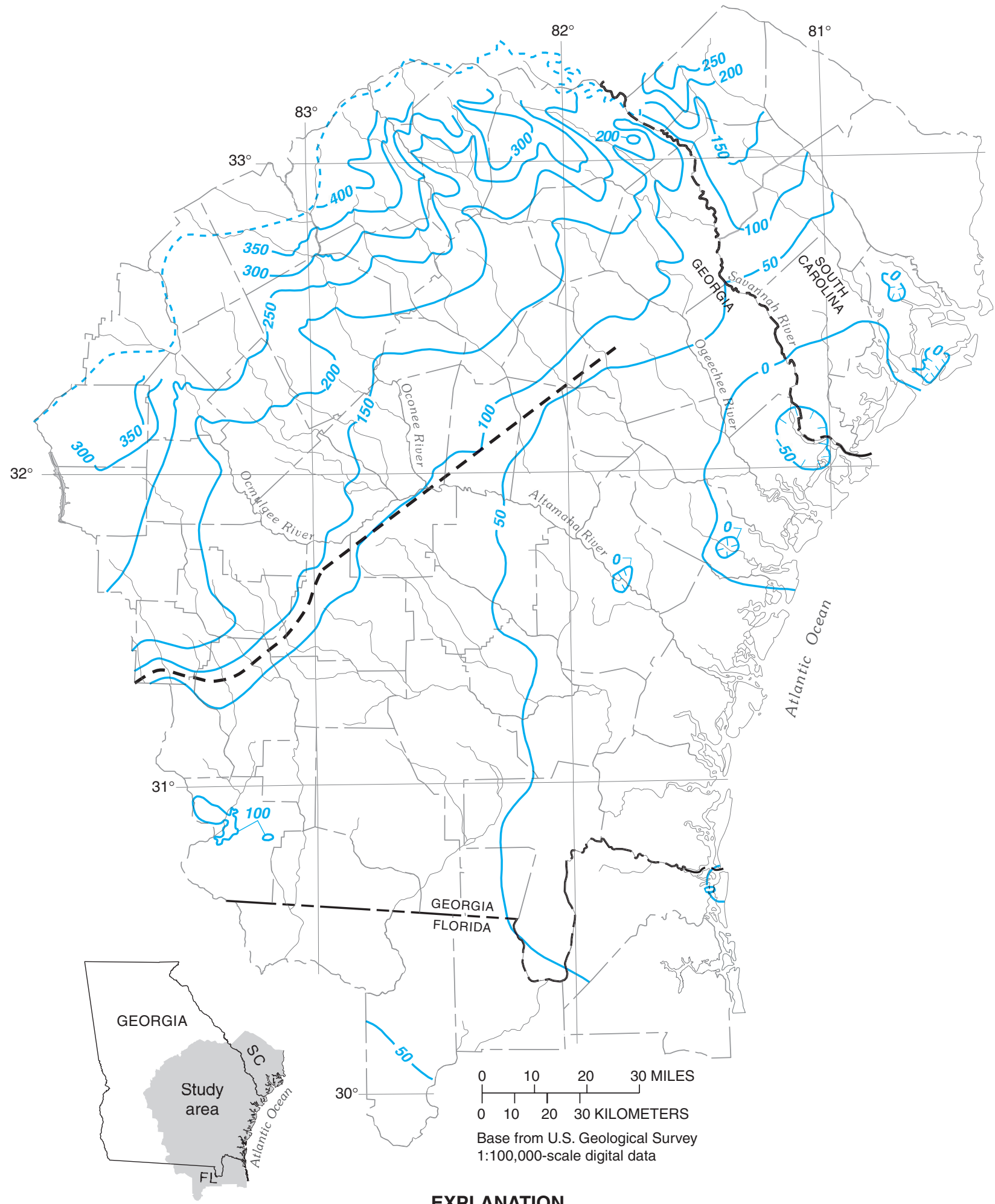

- - - Axis of Gulf Trough - Approximately located (Kellam and Gorday, 1990)

- 10 - Potentiometric contour-Shows altitude at which water level would have stood in tightly cased wells during May 1-26, 1998. Hachures indicate depression. Contour interval $10 \mathrm{ft}$. Datum is NAVD 88

Figure 15. Potentiometric surface of the Upper Floridan aquifer, May 1998. 


\section{Hydrograph Separation}

Hydrograph separation was completed on streamflow data using HYSEP, a computer program that uses mathematical techniques to separate streamflow into baseflow and runoff components (Sloto and Crouse, 1996). The mathematical formulation of HYSEP does not consider the geology of the basin; therefore, it can be used on a site-by-site basis in any hydrologic setting. There are limitations on its use, however, because HYSEP bases hydrograph separation only on basin area and streamflow hydrograph characteristics.

Estimates of baseflow from HYSEP were used to determine changes in baseflow contribution during a variety of climatic conditions. Baseflow estimates are affected by regulation of flows and physical properties of the basin such as vegetation cover, slope, area, shape, land use, soil thickness, and infiltration capacity (Horton, 1933; Riggs, 1963; Bevans, 1986; Sloto and Crouse, 1996), as well as antecedent soil moisture and depth to ground water. The river or tributary at each station selected for HYSEP analysis had negligible diversion or regulation upstream, a drainage area less than $1,400 \mathrm{mi}^{2}$, and at least 31 years of continuous record (table 3 ). The accuracy of the estimates depends on the period of record used (Sloto and Crouse, 1996) and the size of the drainage basin (Pettyjohn and Henning, 1979). A long-term record with representative long-term climatological conditions provides a more reliable baseflow estimate because periods of extreme dry or extreme wet climates would have less influence (Sloto and Crouse, 1996). In addition, the river or tributary at each station was not dominated by losing reaches, interaction with deeper aquifers, evapotranspiration effects, or prolonged periods of surface runoff.
During 1971-2001, baseflow represented a greater portion of streamflow during years of lower rainfall, and a lower portion during years of higher rainfall. At the eight stations selected for HYSEP, mean annual baseflow was from 39 to 74 percent of streamflow, with a mean contribution of 58 percent (table 3). Figure 16 shows the amount of streamflow at the Canoochee River (station 02203000) in the lower Coastal Plain near Claxton, Ga., originating from baseflow for average, wet, and dry years (based on the Brooklet NWS station). During a high-precipitation year, baseflow accounted for 48 percent of total streamflow; during an average-precipitation year, about 63 percent; and during a low-precipitation year, about 60 percent. During dry periods, there is a reduction in runoff, and baseflow becomes the major contributor to streamflow. During drought conditions, there is less water available to recharge the aquifer, as indicated by ground-water level declines. As ground-water levels drop, the hydraulic gradient between the stream and aquifer decreases, reducing groundwater discharge to streams. In some instances, the gradient between the stream and aquifer reverses and stream-water discharges into the aquifer, but this usually is of short duration because the streambed eventually dries up.

Baseflow estimates vary within the upper and lower parts of a basin. Mean annual baseflow for the period 1971-2001 in the upper SSO River Basin ranges from 66 to 74 percent and in the lower basin is 54 percent (table 3). In the upper SAS River Basin, baseflow is about 57 percent of total streamflow at station 02225500 (Ohoopee River). In the lower SAS River Basin, baseflow ranges from about 39 to 43 percent of total streamflow. In the lower part of the Suwannee River Basin, baseflow is about 56 percent of total streamflow. Mean annual baseflow was estimated for 1981 and 2000 (drought condi-

Table 3. Summary of mean annual baseflow estimated using HYSEP at selected streamflow gaging stations in the upper and lower parts of the basins in coastal Georgia and South Carolina, 1971-2001.

[in/yr, inch per year; $\mathrm{ft}^{3} / \mathrm{s}$, cubic foot per second; $\mathrm{mi}^{2}$, square mile; part of basin: $\mathrm{U}$, upper; L, lower; do, ditto]

\begin{tabular}{|c|c|c|c|c|c|c|c|c|c|c|c|}
\hline \multirow{3}{*}{$\begin{array}{c}\text { Station } \\
\text { identification }\end{array}$} & \multirow{3}{*}{$\begin{array}{l}\text { Drainage } \\
\text { area }\left(\mathrm{mi}^{2}\right)\end{array}$} & \multirow{3}{*}{$\begin{array}{l}\text { Part of } \\
\text { basin }\end{array}$} & \multirow{3}{*}{$\begin{array}{l}\text { Period of record } \\
\text { (calendar year) }\end{array}$} & \multirow{3}{*}{$\begin{array}{c}\text { Station } \\
\text { identification }\end{array}$} & \multirow{3}{*}{$\begin{array}{l}\text { Outcropping hydro- } \\
\text { geologic unit }\end{array}$} & \multirow{3}{*}{ in/yr } & \multirow{3}{*}{$\mathrm{ft}^{3} / \mathrm{s}$} & \multicolumn{4}{|c|}{ Mean annual baseflow } \\
\hline & & & & & & & & \multicolumn{4}{|c|}{ (in percent of total streamflow) } \\
\hline & & & & & & & & 1971-2001 & 1981 & 2000 & 1997 \\
\hline 02175500 & 341 & $\mathrm{U}$ & 1951-01 & 02175500 & Upper Three Runs & 9.79 & 246.0 & 69 & 77 & 65 & 64 \\
\hline 02197600 & 28 & $\mathrm{U}$ & $1958-01$ & 02197600 & do. & 8.02 & 16.5 & 66 & 74 & 81 & 68 \\
\hline 02203000 & 555 & $\mathrm{~L}$ & 1937-01 & 02203000 & Surficial & 6.29 & 257 & 54 & 51 & 51 & 48 \\
\hline \multicolumn{12}{|c|}{ Altamaha-Satilla-St Marys River Basin } \\
\hline 02225500 & 1,110 & $\mathrm{U}$ & 1903-07, 37-01 & 02225500 & Surficial & 7.16 & 585 & 57 & 53 & 62 & 56 \\
\hline 02226500 & 1,190 & $\mathrm{~L}$ & 1937-01 & 02226500 & do. & 5.41 & 478 & 43 & 47 & 34 & 47 \\
\hline Mean of station & as for each & period & & & & & & 58 & 57 & 57 & 55 \\
\hline
\end{tabular}


tions) and 1997 (year most representative of mean annual precipitation for the period 1971-2001). Mean annual baseflow was greater in the upper part of the SSO and SAS River Basins than in the lower parts (table 3). The average mean annual baseflow for the 31-year period was 58 percent; for 1981 and 2000, 57 percent each; and for 1997, 55 percent. The difference in baseflow is attributed to variations in topography, geology, and vegetation in the upper and lower Coastal Plain. The upper Coastal Plain is characterized by steep slopes and porous sand and gravel soils that have high infiltration rates and support little vegetation. In this area, aquifers are shallower than in the lower Coastal Plain because the topographic relief is greater in the upper Coastal Plain. The steeper topography results in deeper incision of streams into the aquifers, thereby increasing baseflow to streams. Gentle slopes that facilitate low runoff and more abundant vegetation, which derive water from soil moisture, characterize the lower Coastal Plain. In these areas, the streams do not incise into the more deeply buried aquifers, resulting in lower baseflow. Hydraulic conductivity of an aquifer, which also can have an effect on ground-water discharge, was not studied for this report.

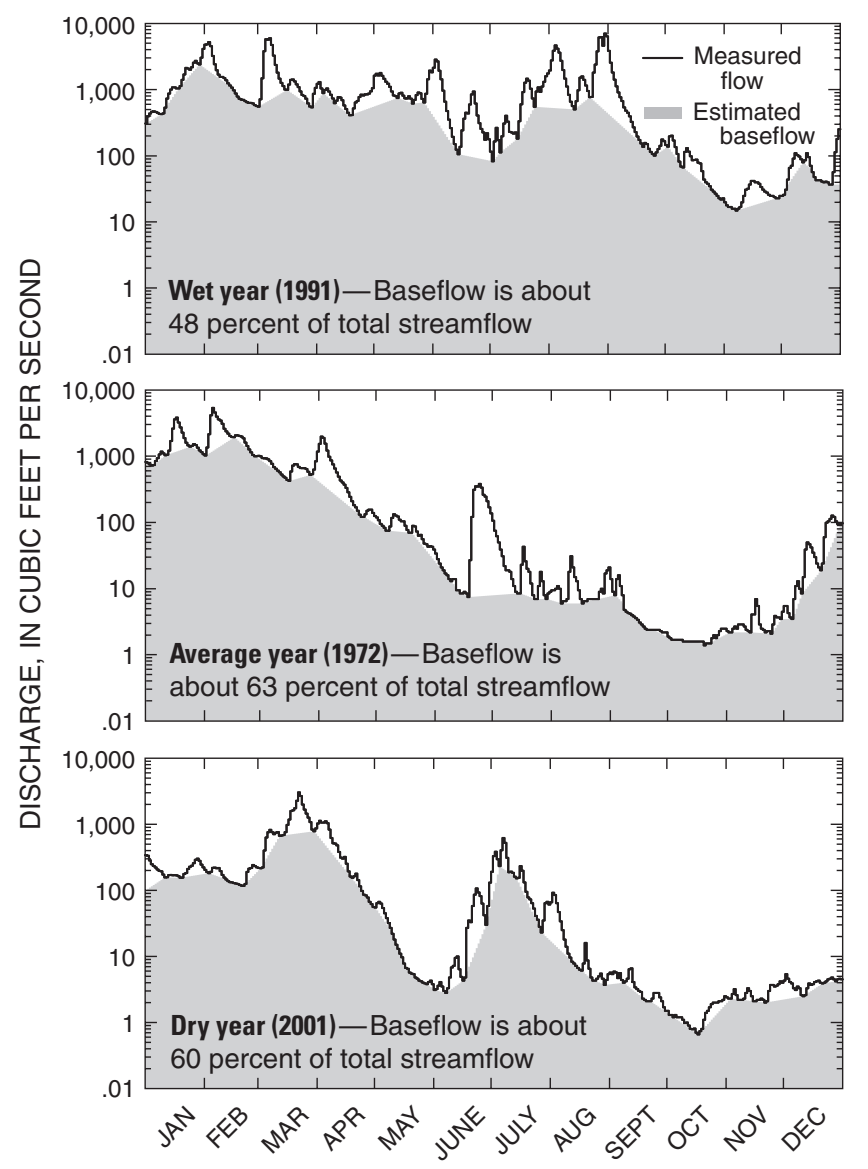

Figure 16. Baseflow separation using the local-minimum method for the wet, average, and dry years at Canoochee River (station 02203000) near Claxton, Georgia, 1971-2001.

\section{Drought Streamflow}

Drought streamflow represents a quantitative estimate of minimum ground-water discharge to streams because during drought periods, streamflow is composed mostly of baseflow. Drought baseflow is a minimum estimate because groundwater levels are lowered during droughts; and as a result, less water is available to the streams than would be available during average precipitation conditions. During droughts, streams receive baseflow mostly from the intermediate and regional flow systems because the water level in the local flow system is substantially decreased (Faye and Mayer, 1990). Streamflow at selected stations was compiled for the 1954 (Thomson and Carter, 1955), 1981 (Carter, 1983; Faye and Mayer, 1990), and 2000 drought years (table 4). Streamflow was normalized to unit-area discharge to separate out effects of basin size on discharge rates. The computed unit-area discharge was estimated for selected stations in the SSO, SAS and Suwannee River Basins. The minimum streamflow during each calendar year was used in the calculations.

A comparison of the unit-area discharge in the upper and lower Coastal Plain was made in the SSO River Basin, using data from the 1954, 1981, and 2000 drought years. Streamflow data were collected on the same date from two adjacent stations (02197830 and 02198000) along Brier Creek near Waynesboro, Ga., and Millhaven, Ga. (fig. 17). During the 1954 and 2000 droughts, streamflow along that reach decreased in response to the droughts. During 1954, unit-area discharge decreased from 0.23 to $0.16\left(\mathrm{ft}^{3} / \mathrm{s}\right) / \mathrm{mi}^{2}$ from Waynesboro, Ga., to Millhaven, Ga., a distance of about $20 \mathrm{mi}$. During 2000, unit-area discharge decreased from 0.32 to $0.25\left(\mathrm{ft}^{3} / \mathrm{s}\right) / \mathrm{mi}^{2}$ from Waynesboro to Millhaven. There was no significant change in unit-area discharge between the two stations during 1981. For this comparison, these discharge measurements were made on the same date at each site (fig. 17). A comparison of the lowest discharge measured between the two stations for the calendar years 1954, 1981, and 2000 shows a decrease in unit-area discharge from 0.23 to $0.10\left(\mathrm{ft}^{3} / \mathrm{s}\right) / \mathrm{mi}^{2}$ from Waynesboro to Millhaven for 1954 ; no change for 1981; and a decrease from 0.32 to $0.18\left(\mathrm{ft}^{3} / \mathrm{s}\right) / \mathrm{mi}^{2}$ for 2000. Similar comparisons were not made in the SAS or Suwannee River Basins because of insufficient data (table 4).

Drought unit-area discharge shows little variation among the three basins, with a few exceptions. In the SSO River Basin, the median unit-area discharge was 0.11 cubic feet per second per square mile $\left(\mathrm{ft}^{3} / \mathrm{s}\right) / \mathrm{mi}^{2}$ for the 1954 drought, $0.11-0.14\left(\mathrm{ft}^{3} / \mathrm{s}\right) / \mathrm{mi}^{2}$ for the 1981 drought, and $0.18\left(\mathrm{ft}^{3} / \mathrm{s}\right) / \mathrm{mi}^{2}$ for the 2000 drought. During each drought period, unitarea discharge generally was higher for the stations in the upper Coastal Plain than for stations in the lower Coastal Plain. During the 1954 drought, seven stations in the upper Coastal Plain had unit-area discharges ranging from 0.08 to $0.63\left(\mathrm{ft}^{3} / \mathrm{s}\right) / \mathrm{mi}^{2}$ (table 4$)$. The unit-area discharge ranged from 0 to $0.56\left(\mathrm{ft}^{3} / \mathrm{s}\right) / \mathrm{mi}^{2}$ at 15 stations in the lower Coastal Plain during 1954. During 1981, two stations in the upper Coastal Plain had unit-area discharge of 0.14 and $0.18\left(\mathrm{ft}^{3} / \mathrm{s}\right) / \mathrm{mi}^{2}$; 


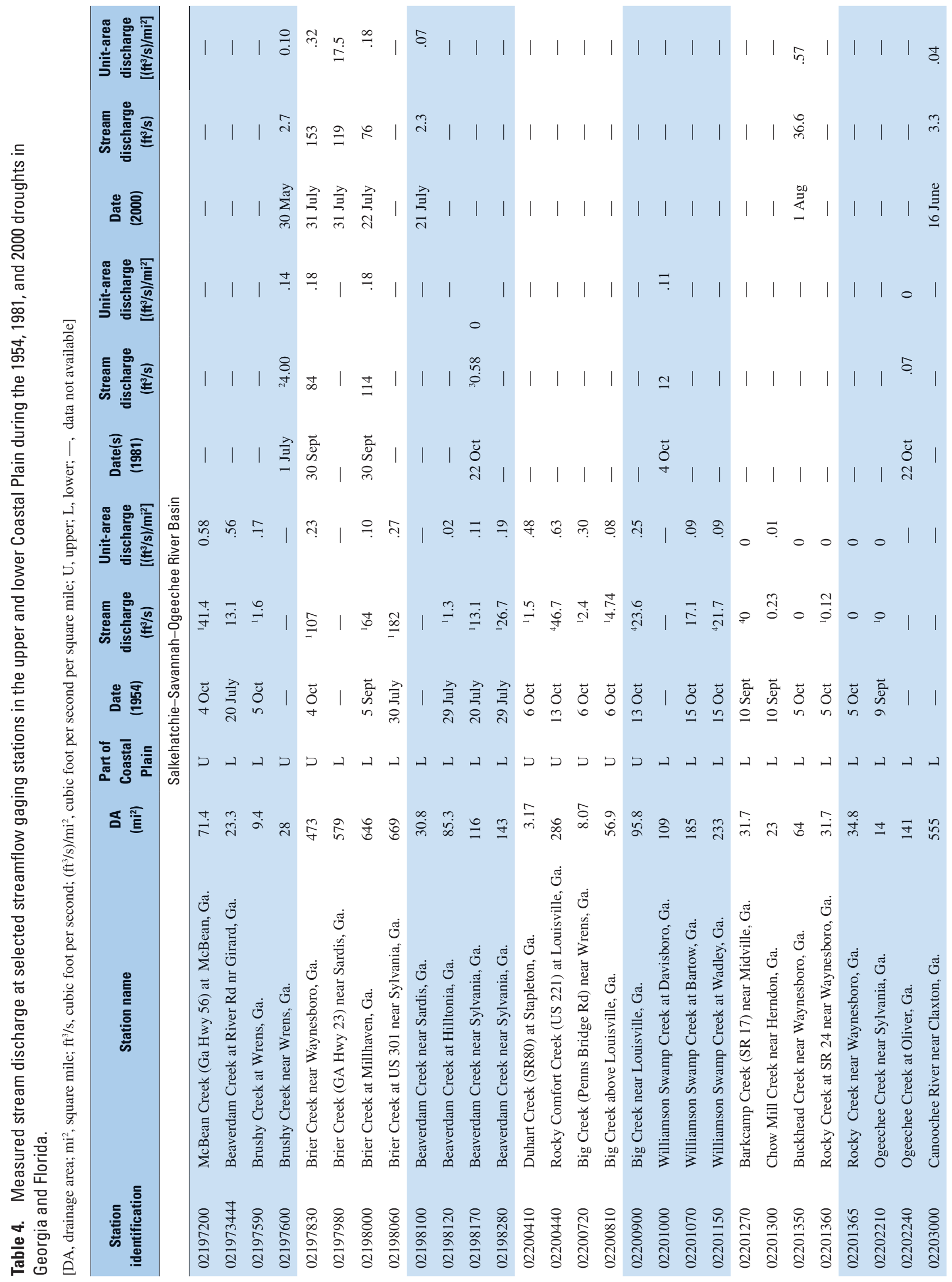




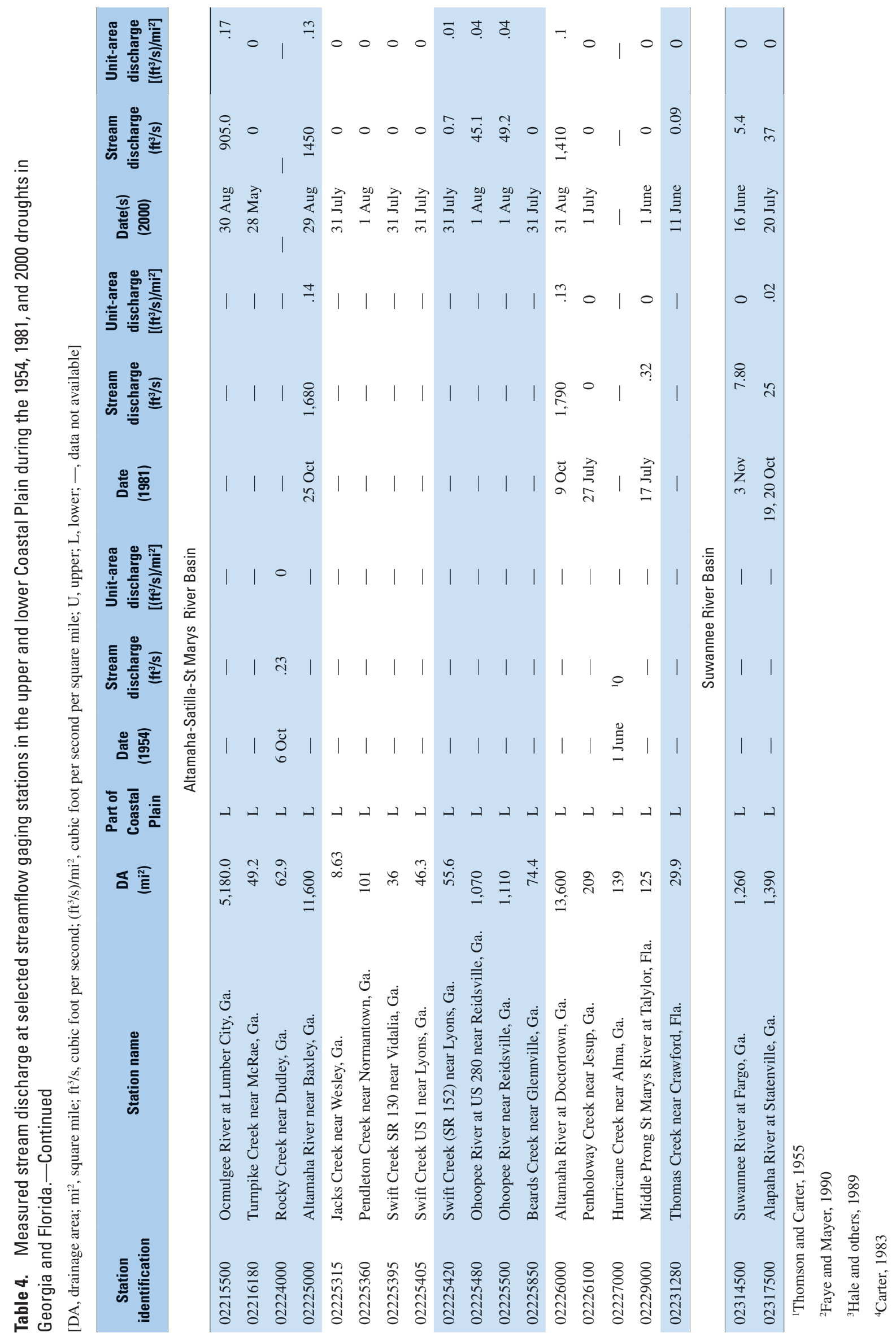

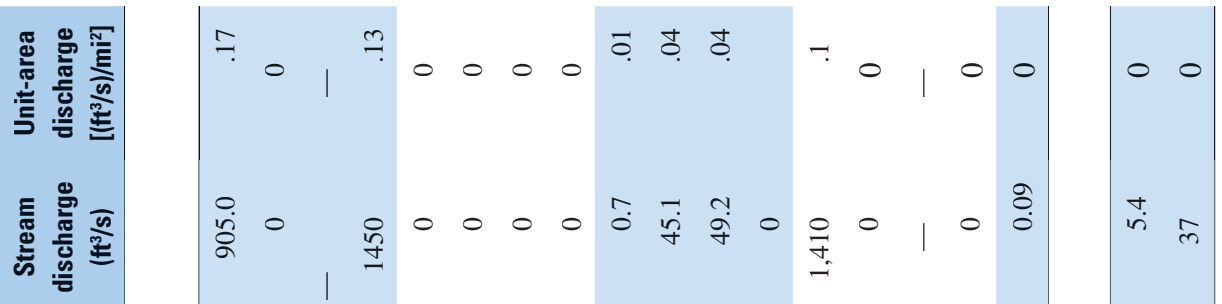

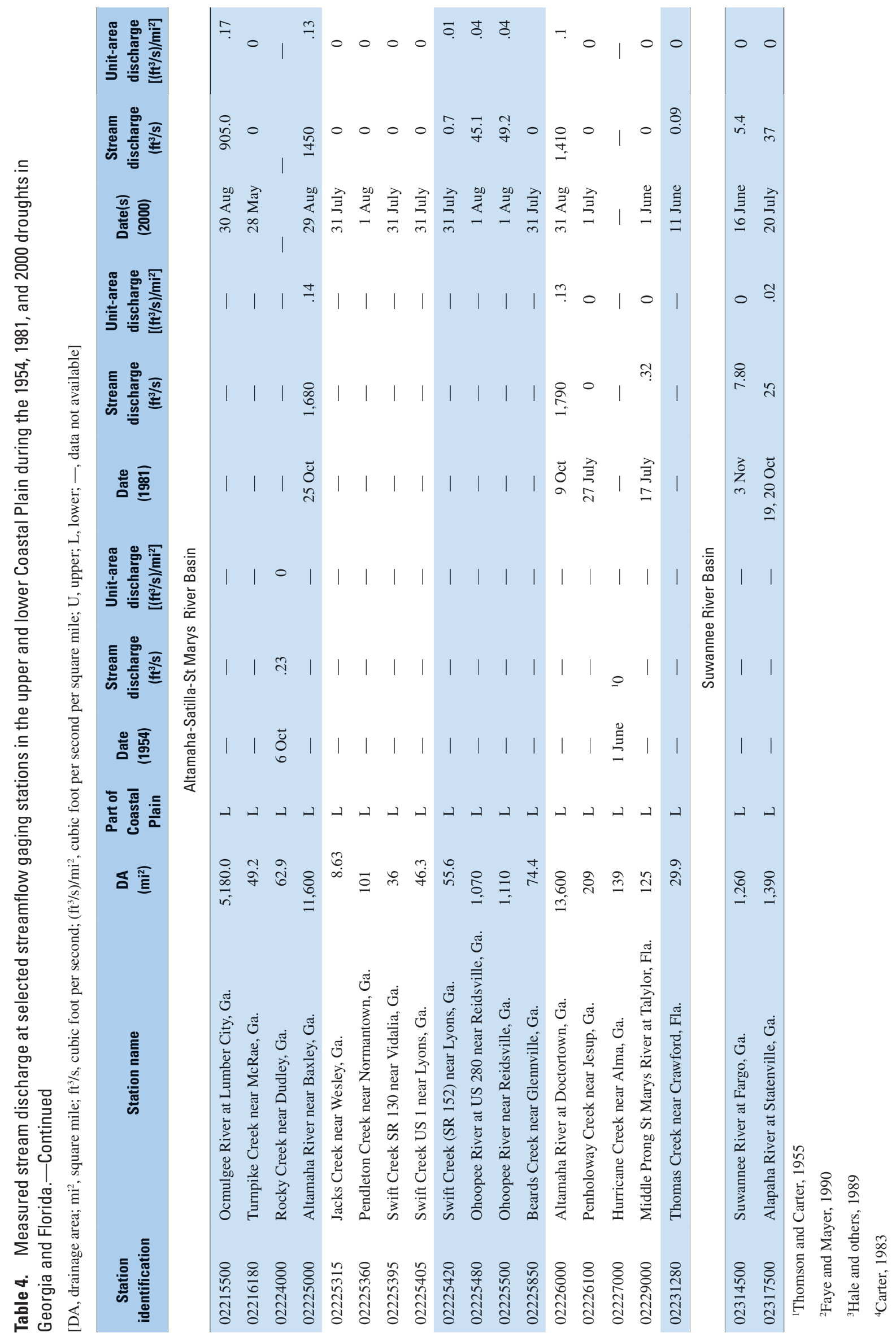

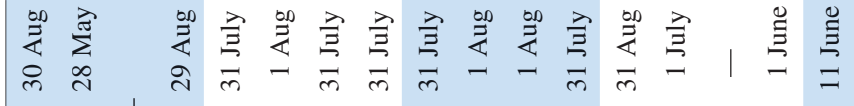

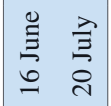

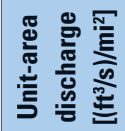
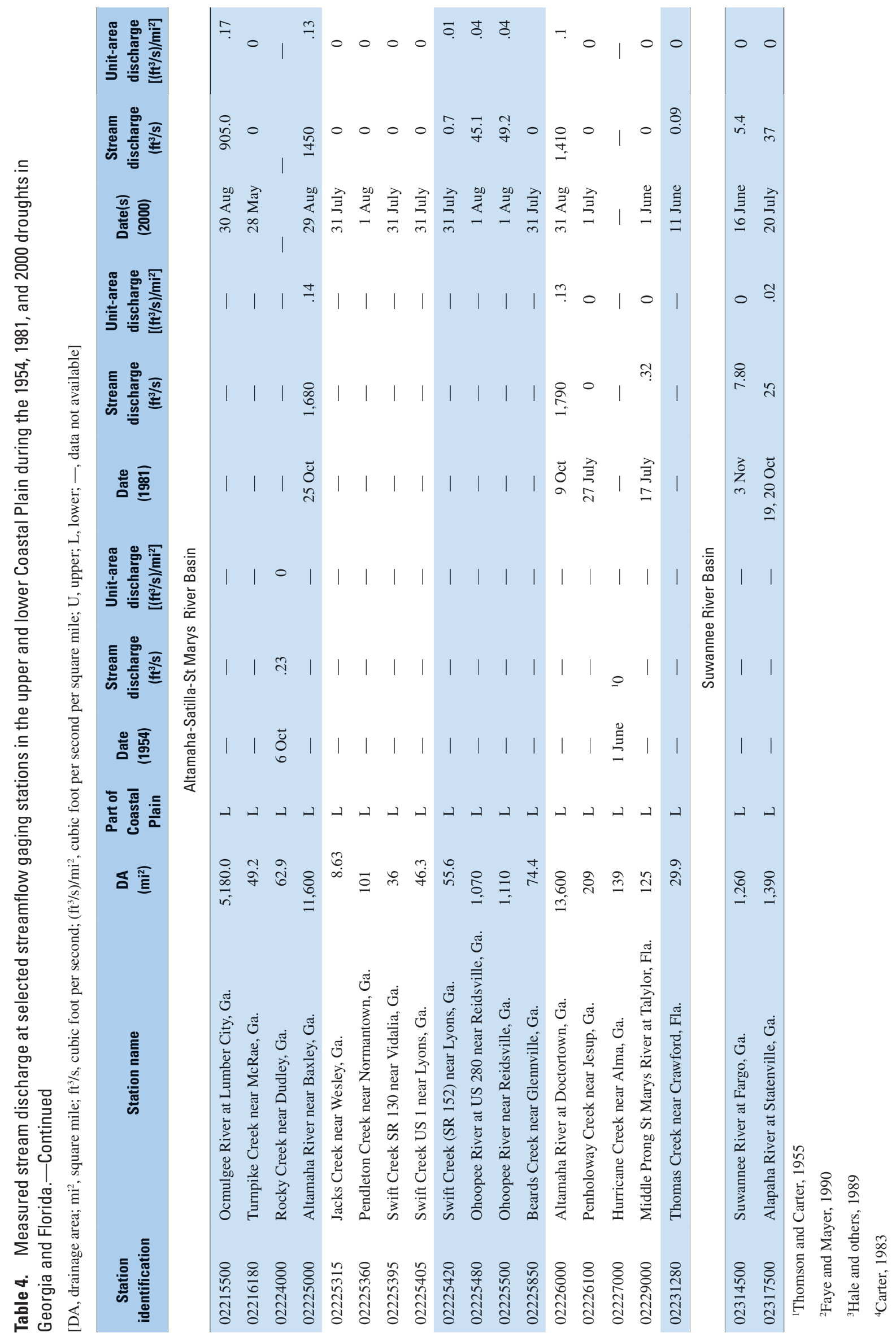

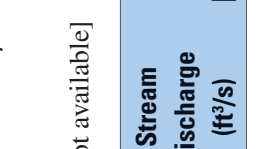

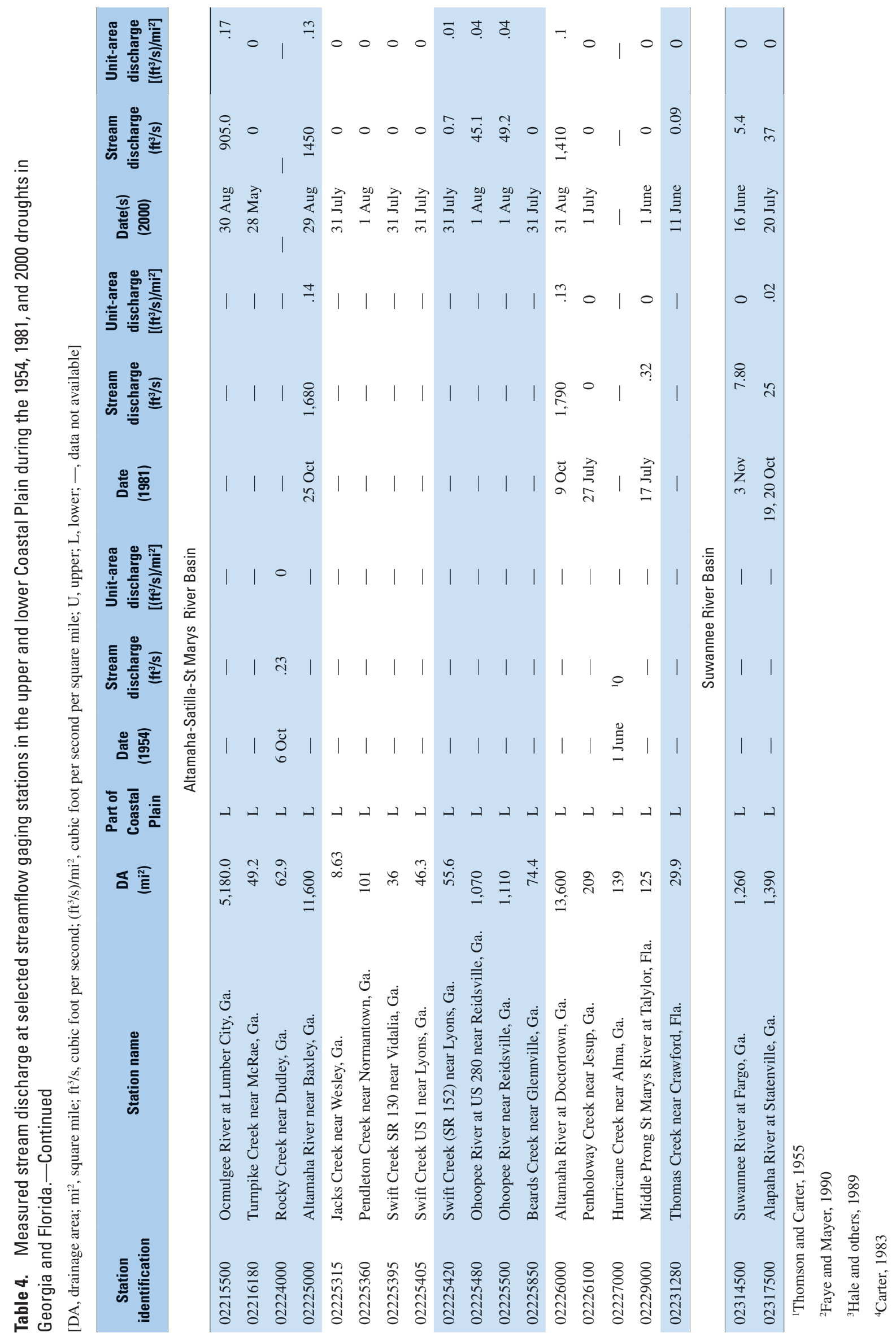




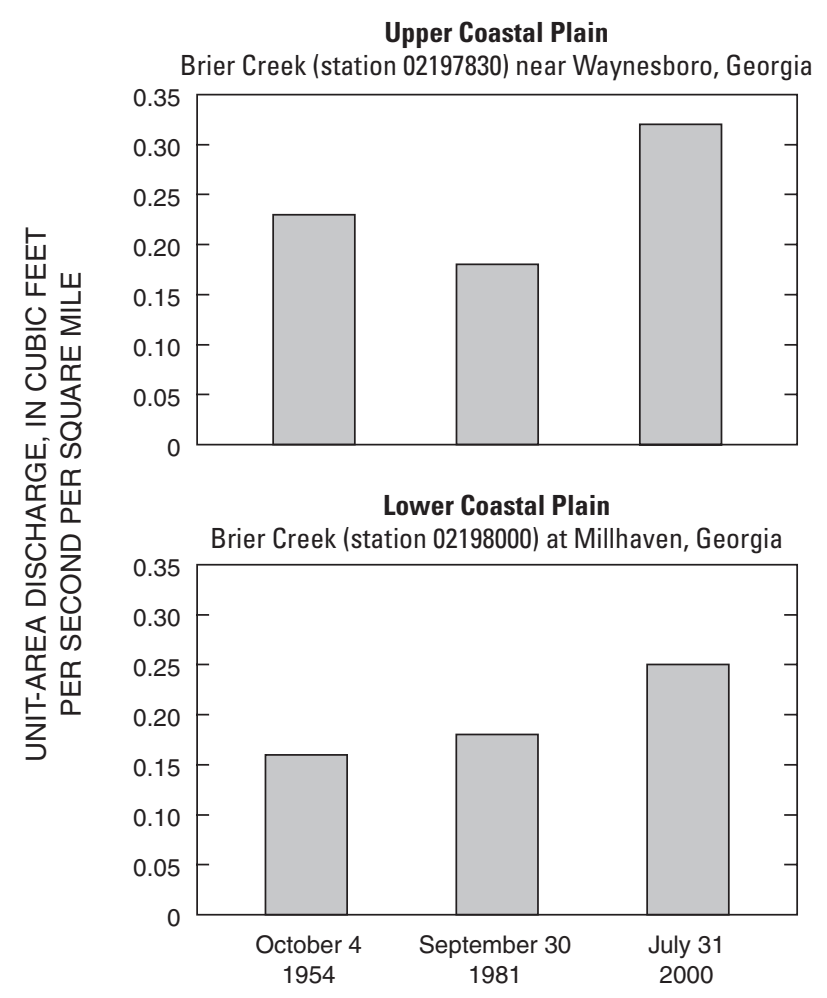

Figure 17. Comparison of drought streamflow between two adjacent streamflow gaging stations in the SalkehatchieSavannah-Ogeechee River Basin.

whereas, four stations in the lower Coastal Plain had unit-area discharge ranging from 0 to $0.18\left(\mathrm{ft}^{3} / \mathrm{s}\right) / \mathrm{mi}^{2}$ (table 4). During 2000, two stations in the upper Coastal Plain had unit-area discharge of 0.10 and $0.32\left(\mathrm{ft}^{3} / \mathrm{s}\right) / \mathrm{mi}^{2}$, and five stations in the lower Coastal Plain had unit-area discharge ranging from 0.04 to $17.5\left(\mathrm{ft}^{3} / \mathrm{s}\right) / \mathrm{mi}^{2}$ (table 4$)$. The relatively higher contribution of baseflow in the upper Coastal Plain compared to the lower Coastal Plain reflects the greater relief, higher interconnection between aquifers and streams, greater soil permeability, and different vegetation.

In the SAS and Suwannee River Basins, all stations are located in the lower Coastal Plain. In the SAS River Basin, the unit-area discharge was $0\left(\mathrm{ft}^{3} / \mathrm{s}\right) / \mathrm{mi}^{2}$ for two stations during 1954; ranged from 0 to $0.14\left(\mathrm{ft}^{3} / \mathrm{s}\right) / \mathrm{mi}^{2}$ for four stations during 1981; and ranged from 0 to $0.17\left(\mathrm{ft}^{3} / \mathrm{s}\right) / \mathrm{mi}^{2}$ for 15 stations during 2000 (table 4). In the Suwannee River Basin, the unitarea discharge for two stations was 0 and $0.02\left(\mathrm{ft}^{3} / \mathrm{s}\right) / \mathrm{mi}^{2}$ during 1981; $0\left(\mathrm{ft}^{3} / \mathrm{s}\right) / \mathrm{mi}^{2}$ during 2000; no data were available for 1954 (table 4).

Observed differences in streamflow between upstream and downstream stations give an indication of the gain or loss of water from or to the ground-water flow system. In the SSO and SAS River Basins, near-concurrent discharge measurements taken at partial-record stations and daily mean flow at continuous-record stations during the three drought periods were used to estimate ground-water discharge to selected reaches. Observed gains or losses along selected stream reaches were determined in the SSO and SAS River Basins during the 1954, 1981, and 2000 droughts (table 5). Gain or loss determinations were not made in the Suwannee River Basin because of insufficient data.

In the SSO River Basin, ground water provided baseflow to most stream reaches evaluated during the 1954, 1981, and 2000 droughts. In some reaches, streams were either dry or lost water to the ground-water system. For example, in the Brier Creek Basin, during the 1954 drought, a loss of $0.25\left(\mathrm{ft}^{3} / \mathrm{s}\right) / \mathrm{mi}^{2}$ was measured between stations 02197830 and 02198000 (fig. 18; table 5). In this same reach during the 1981 drought, a gain of $0.17\left(\mathrm{ft}^{3} / \mathrm{s}\right) / \mathrm{mi}^{2}$ was measured (fig. 19; table 5). During the 2000 drought, a loss of $0.45\left(\mathrm{ft}^{3} / \mathrm{s}\right) / \mathrm{mi}^{2}$ was measured (fig. 20; table 5) in the same reach. Losses were observed in the SSO River Basin at Rocky Creek between stations 02201360 and 02201365 in 1954 (fig. 18; table 5) and in the SAS River Basin along the Altamaha River between stations 02225000 and 02226000 during 2000 (fig. 20; table 5). Losses most likely are due to stream-water seepage into the surficial aquifer along the reach. Gains most likely are due to baseflow.

\section{Linear-Regression Analysis of Streamflow Duration}

A linear-regression analysis was used to develop a relation between mean annual baseflow and flow duration for streams in the study area. A flow-duration curve is a cumulative frequency curve that shows the percentage of time that specified discharges are equaled or exceeded during a given period at stations where continuous records of daily flow are collected. Flow-duration curves integrate the effects of climate, topography, and geology. Visual inspection of the slopes of curves gives some indication of flow from ground water. Ground water dominates streamflow at the inflection point on a curve, where the curve begins to flatten. Generally, steep slopes are indicative of limited basin storage and dominant contribution from runoff, whereas flat slopes are indicative of equal contribution of ground water and runoff (Stricker, 1983) (fig. 21).

Many studies have compared ground-water discharge to streams using the flow-duration characteristics of a stream. Stricker (1983) estimated baseflow using streamflow-duration curves for 35 stations in the southeastern Coastal Plain of South Carolina, Georgia, Alabama, and Mississippi. Stricker (1983) found that the 60- and 65-percent flow-duration points on the flow-duration curves were representative of mean annual baseflow for streams having mean discharges greater than $10 \mathrm{ft}^{3} / \mathrm{s}$. Stricker (1983) found that the shape of streamflow-duration curves is affected by the lithology of the Coastal Plain sediments. Steep curves are associated with basins underlain by low-permeability clay or chalk with high runoff and low baseflow, whereas flatter curves are associated with basins underlain by high-permeability sand and gravel where a high percentage of the discharge is baseflow (Stricker, 1983). 

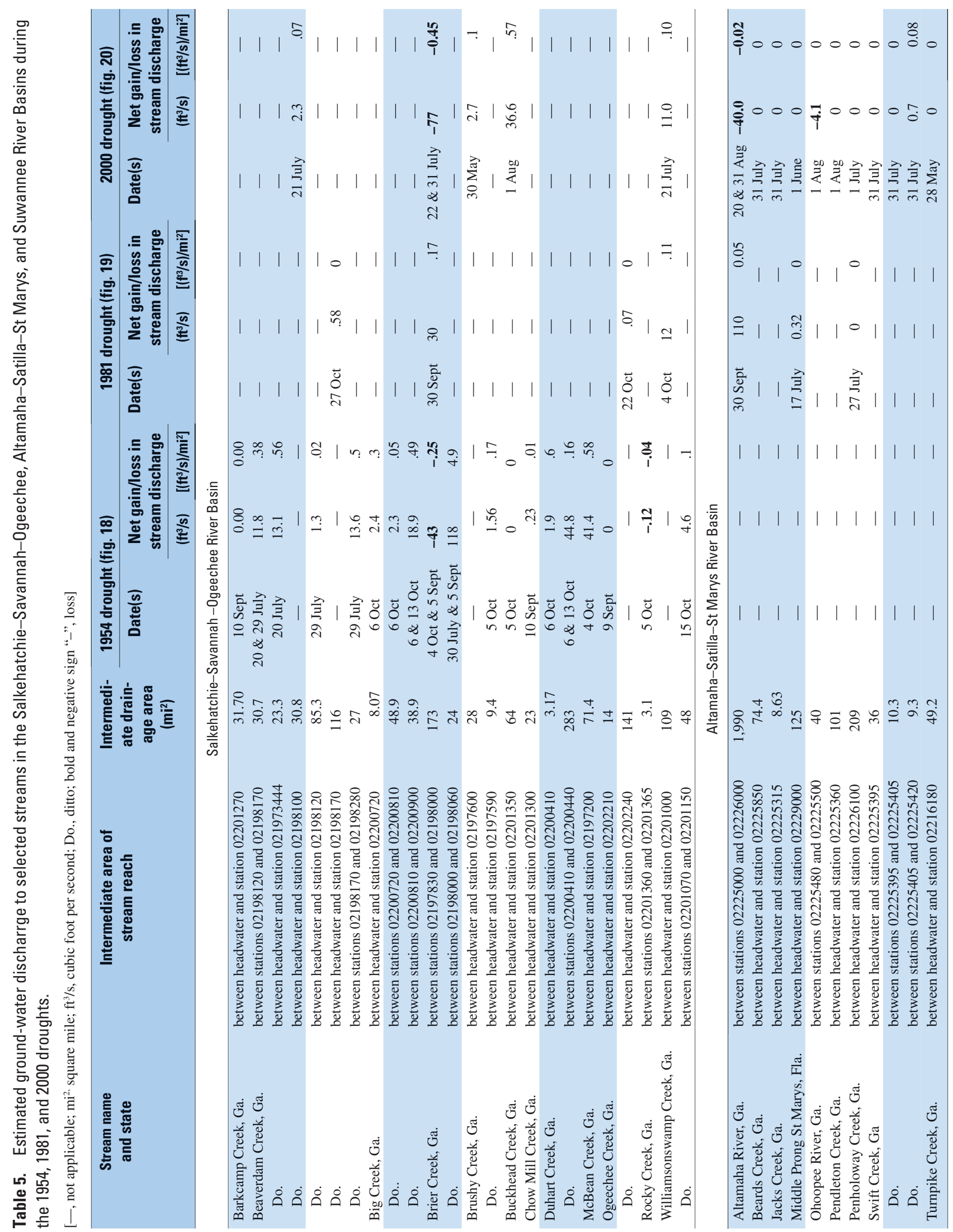

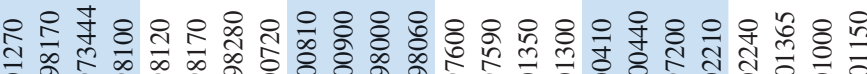

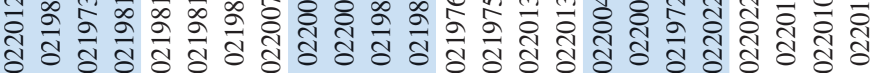

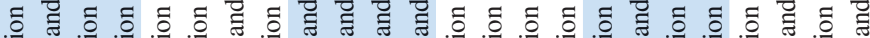

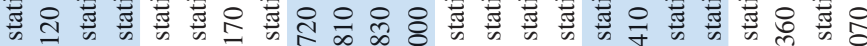

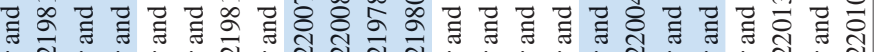
岛

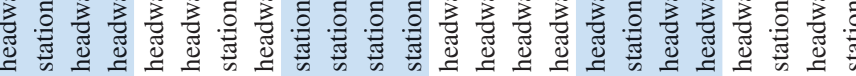

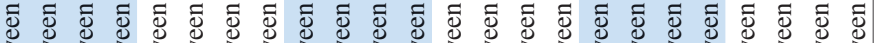

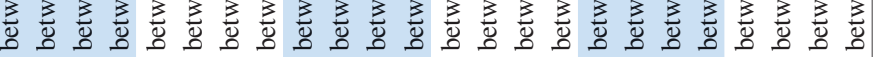

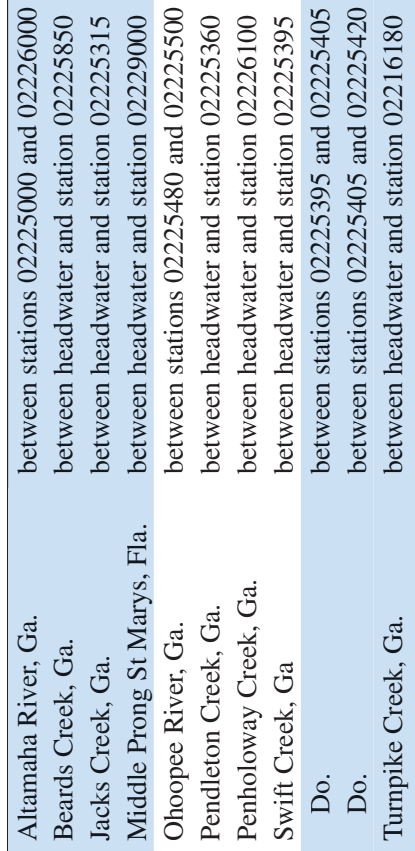


The shape of a flow-duration curve can be described by a streamflow index, modified by Pettyjohn and Henning (1979) as:

$$
\sqrt{\frac{\mathrm{Q}_{25}}{\mathrm{Q}_{75}}},
$$

where $\mathrm{Q}_{25}\left(75^{\text {th }}\right.$ percentile $)$ is the streamflow equaled or exceeded 25 percent of the time and less than or equal to 75 percent of the time; and $\mathrm{Q}_{75}\left(25^{\text {th }}\right.$ percentile $)$ is the streamflow equaled or exceeded 75 percent of the time and less than or equal to 25 percent of the time. Stricker (1983) found that the lower the ratio, the greater the portion of baseflow from ground water.

Discharge data from 14 stations for the period 1971-2001 were analyzed to determine the streamflow index (table 6). Streamflow indices ranged from a low of 1.48 at the Brushy Creek (station 02197600) in the SSO River Basin to a high to 7.31 at Little Satilla River (station 02227500) in the SAS River Basin.
The lowest index in the SSO River Basin is for the station on Brushy Creek near Wrens, Ga. (station 02197600) (fig. 22; table 6), where the lithology is mostly sand interlayered with clay, aquifers are more deeply incised by streams, and ground water contributes a large percentage of baseflow. The flow-duration curve has a gentle slope. Brushy Creek is the only station in the upper Coastal Plain area of the SSO River Basin. The highest index in the SSO River Basin is Canoochee River near Claxton, Ga. (station 02203000) (fig. 23), where the lithology is mostly sand. The curve is steep, indicating high runoff. In this area, aquifers are deeply buried and ground water contributes only a small percentage to baseflow. There appears to be little difference between the flow duration of mean daily streamflows in the upper and lower Coastal Plain in the SSO River Basin. Brushy Creek in the upper Coastal Plain has an index of 1.48, and Brier Creek in the lower Coastal Plain has an index of 1.74 (fig. 22; table 6).

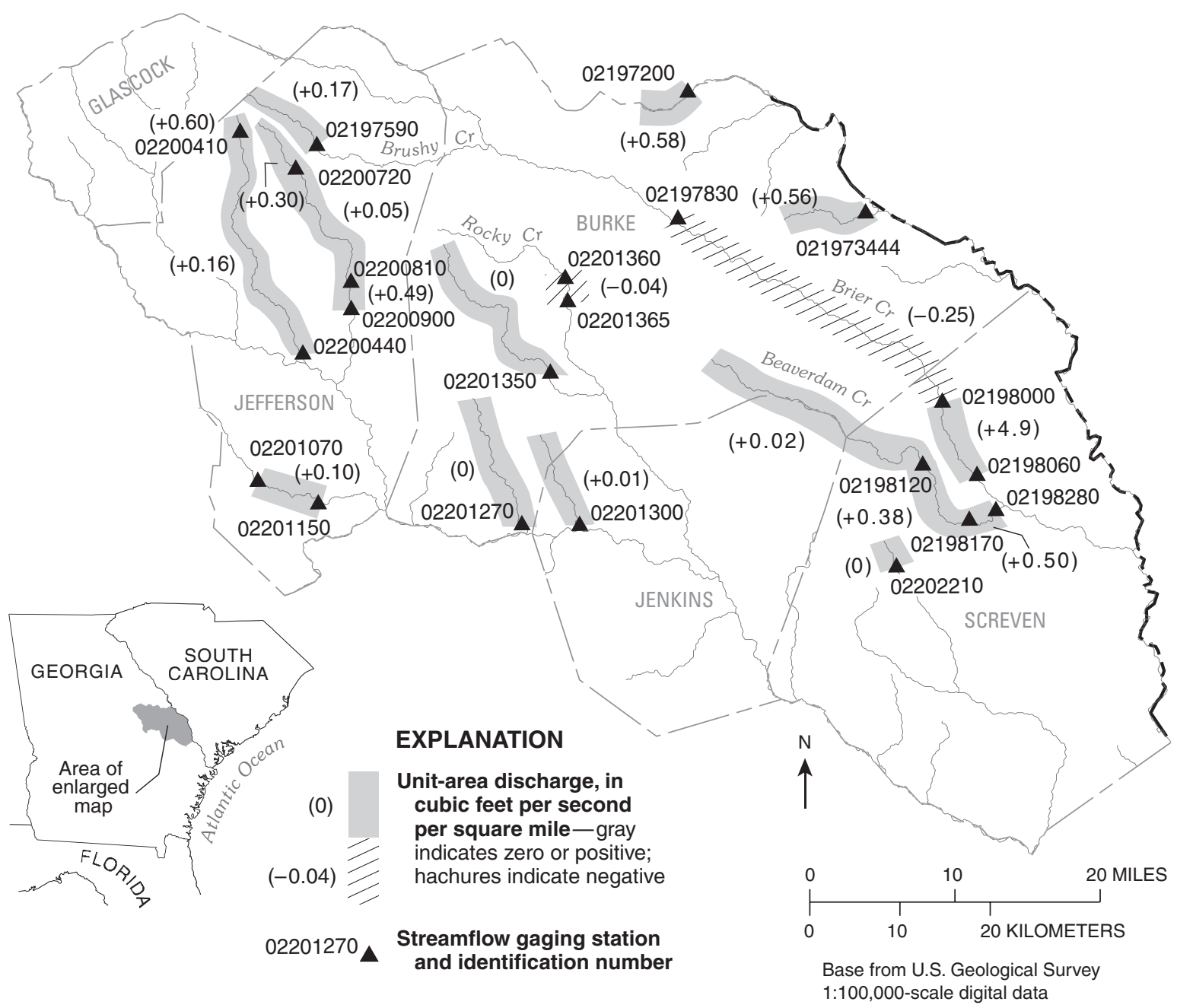

Figure 18. Selected streamflow gaging stations monitored during the 1954 drought and corresponding intermediate unit-area discharge. 


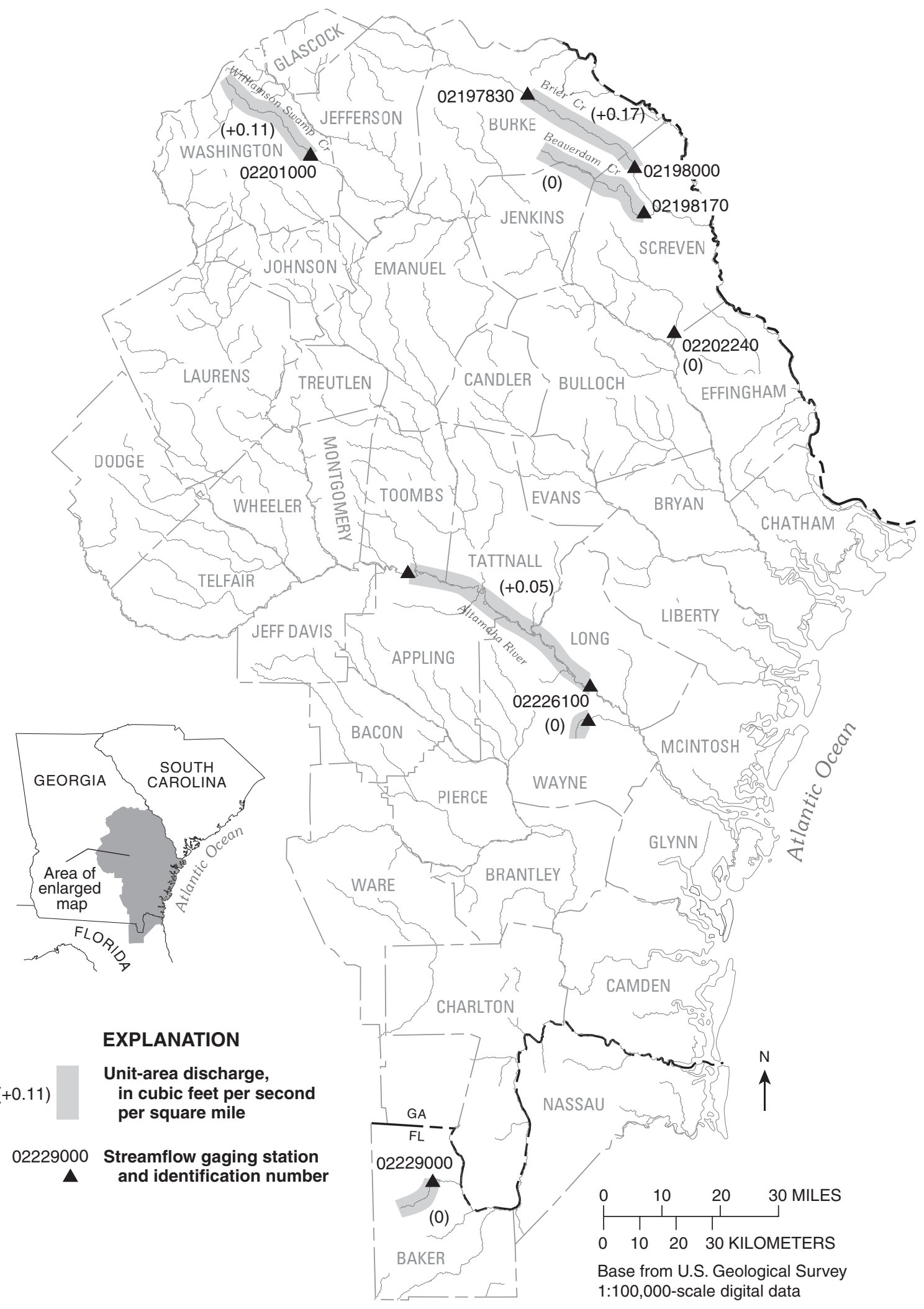

Figure 19. Selected streamflow gaging stations monitored during the 1981 drought and corresponding intermediate unit-area discharge. 


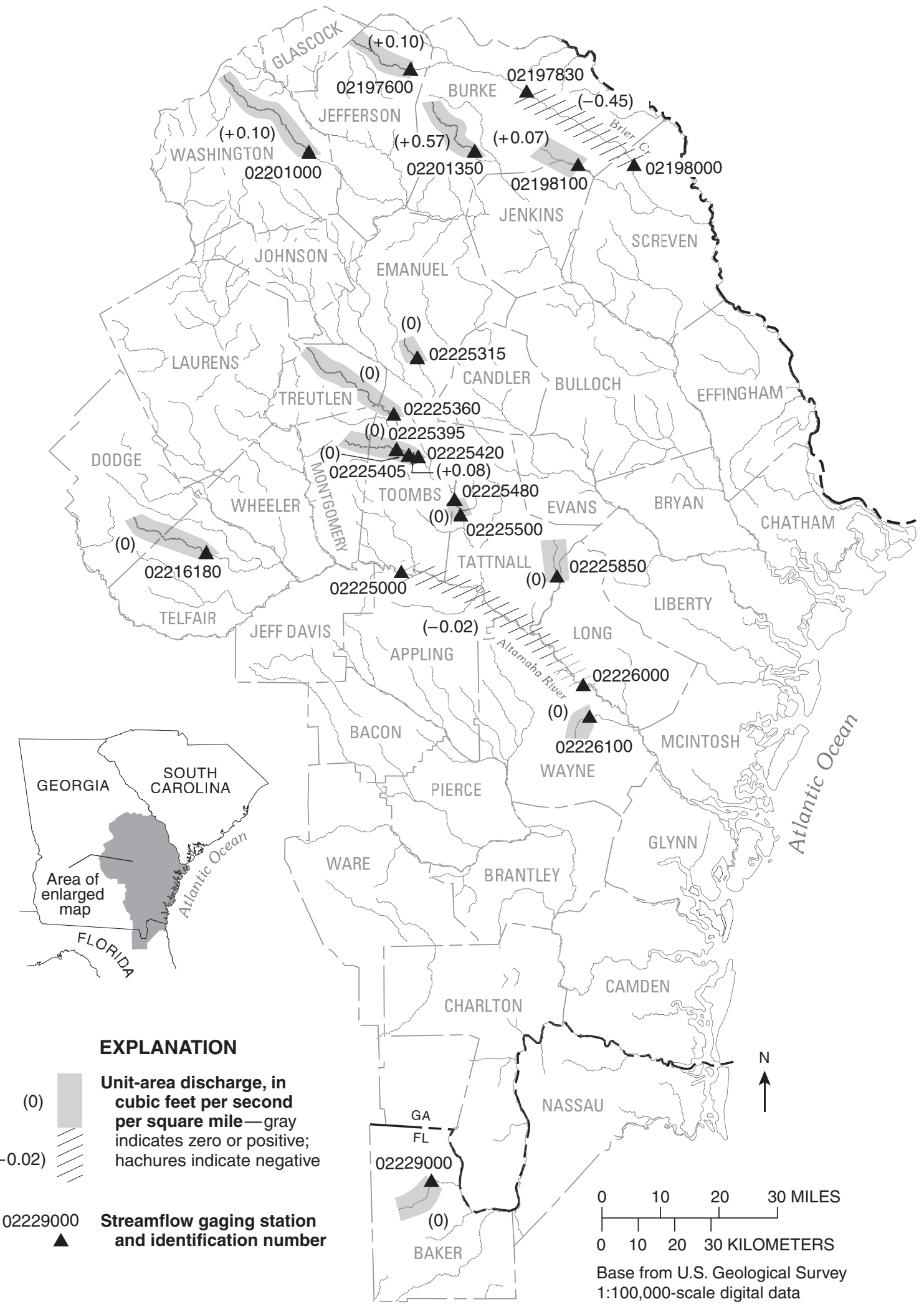

Figure 20. Selected streamflow gaging stations monitored during the 2000 drought and corresponding intermediate unit-area discharge. 


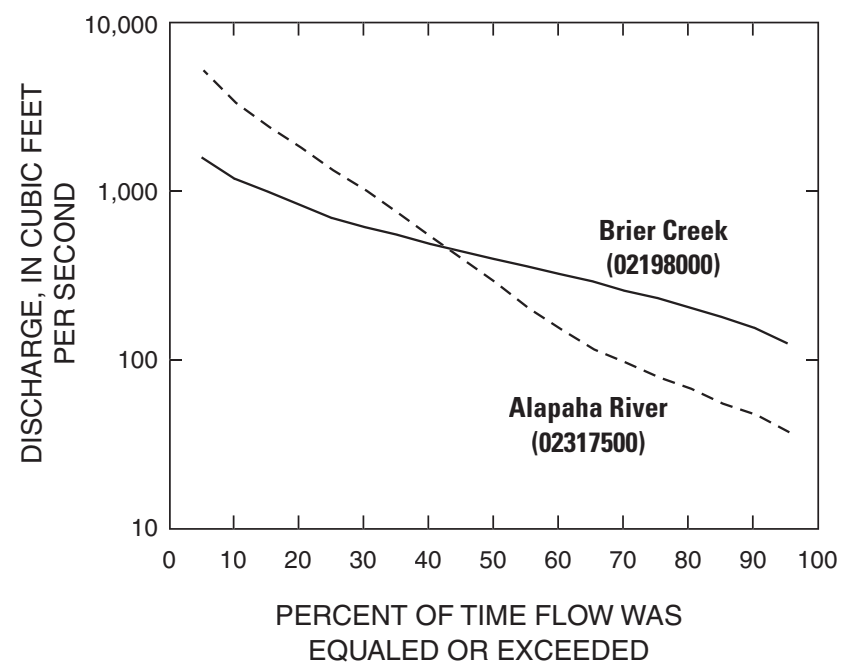

Figure 21. Comparison of two flow-duration curve types: gentle curve along Brier Creek (station 02198000) and a steep curve along the Alapaha River (station 02317500).

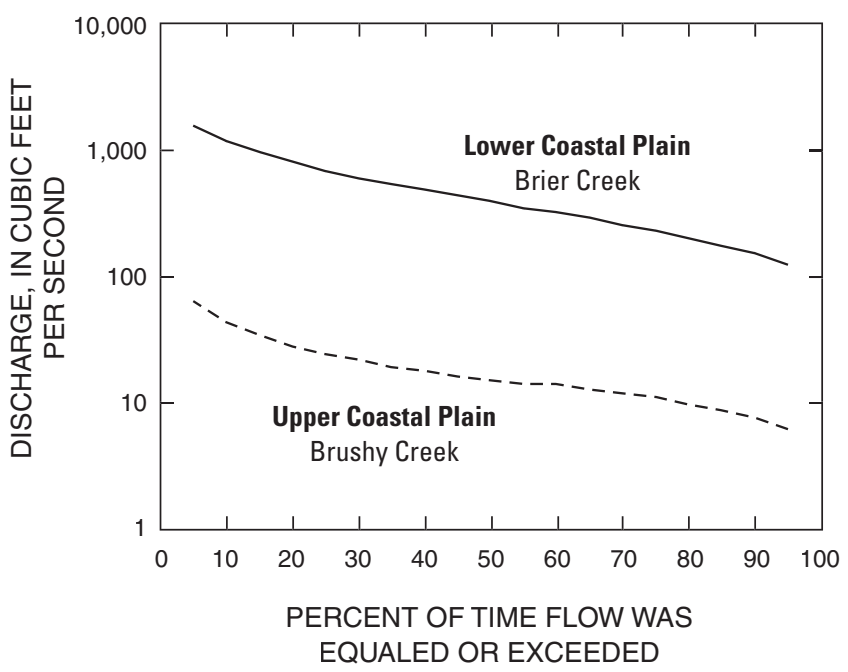

Figure 22. Duration of mean daily streamflow for Brushy Creek (station 02197600) near Wrens, Georgia, and Brier Creek (station 02198000) at Millhaven, Georgia, 1971-2001.

Table 6. Flow-duration curve index $\left[\left(0_{25} / 0_{75}\right)^{1 / 2}\right]$ and curve shape for selected streams in the Salkehatchie-Savannah-0geechee, Altamaha-Satilla-St Marys, and Suwannee River Basins, 1971-2001.

$\left[\mathrm{mi}^{2}\right.$, square mile; $\mathrm{ft}^{3} / \mathrm{s}$, cubic foot per second; part of basin: $\mathrm{U}$, upper; L, lower]

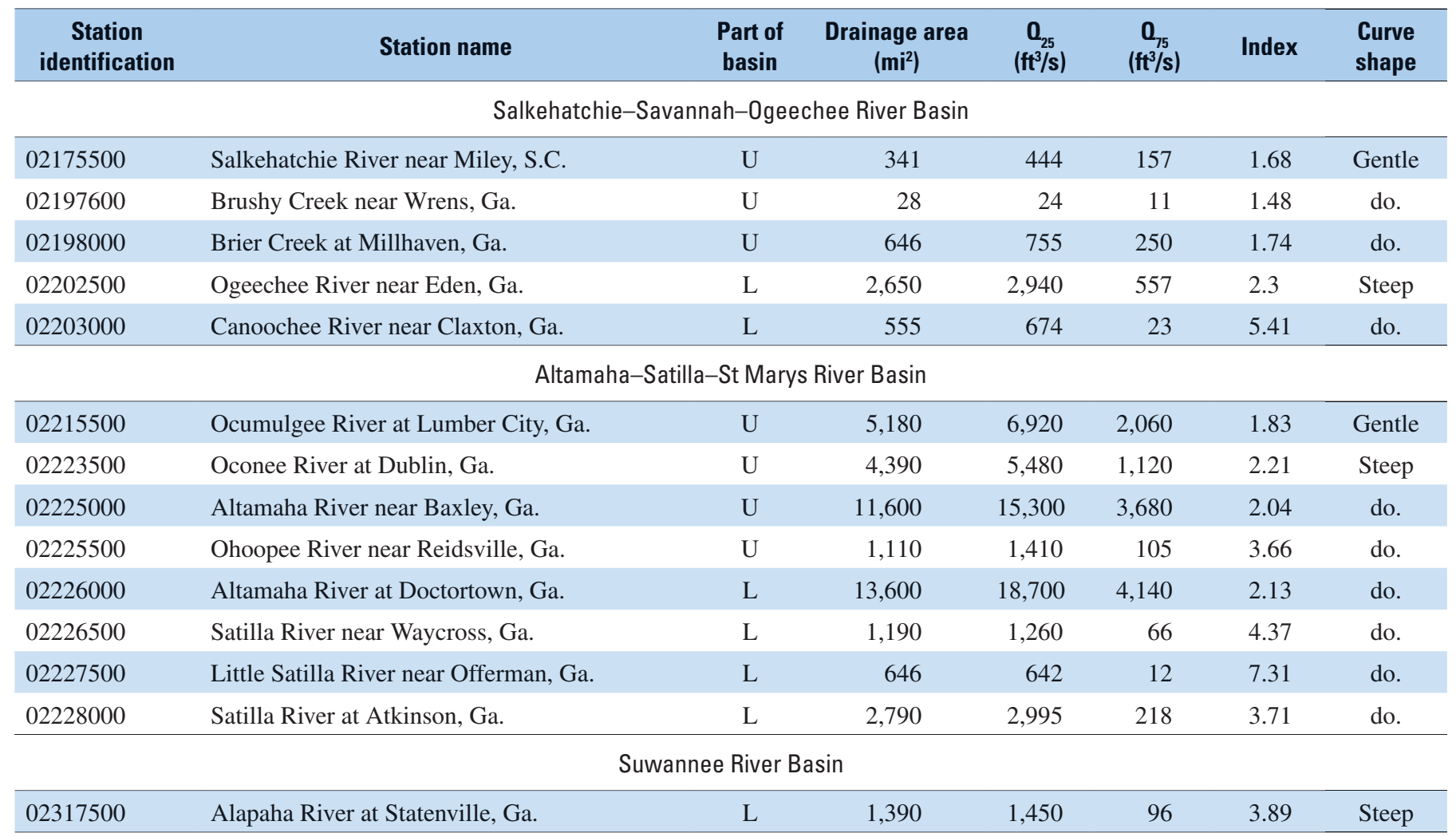




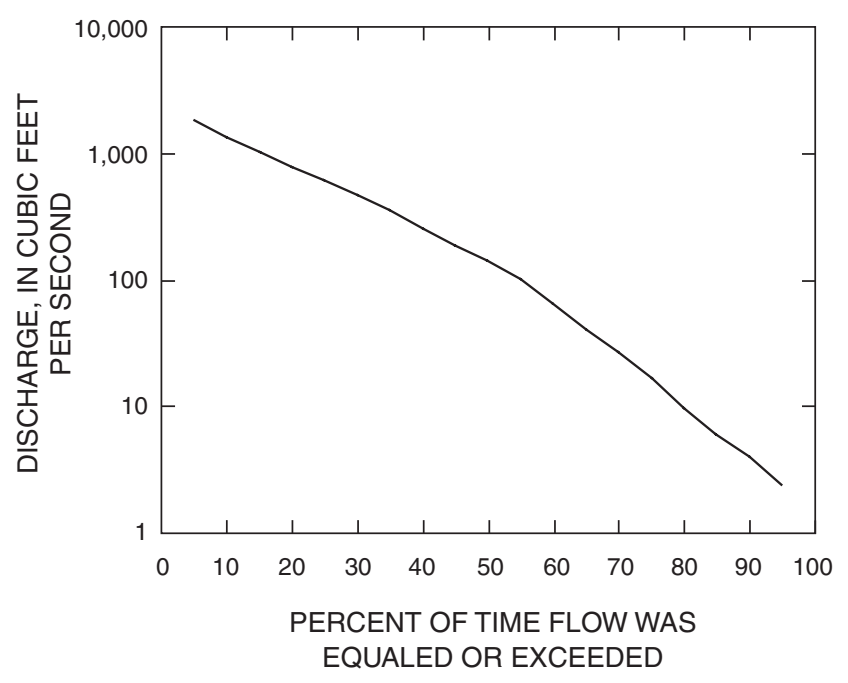

Figure 23. Duration of mean daily streamflow for Canoochee River (station 02203000) near Claxton, Georgia, in the upper Salkehatchie-Savannah-Ogeechee River Basin, 1971-2001.

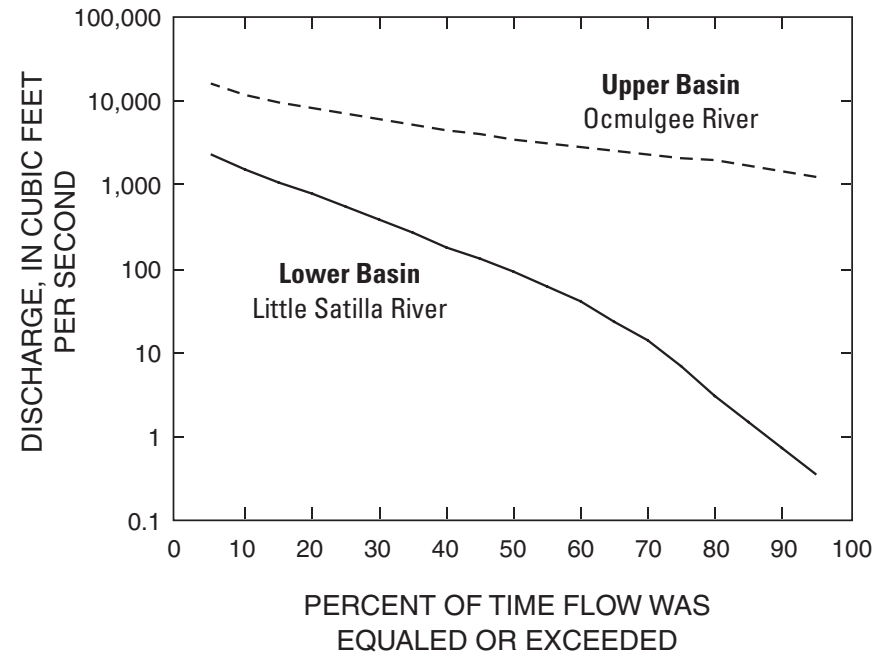

Figure 24. Duration of mean daily streamflow for Little Satilla River (station 02227500) near Offerman, Georgia, and Ocmulgee River (station 02215500) at Lumber City, Georgia, in the Altamaha-Satilla-St Marys River Basin, 1971-2001.
In the SAS River Basin, all measured discharges have indices greater than 2, except the Ocmulgee River, which has an index of 1.83. An index greater than 2 corresponds to a steep slope. The lowest ratio in the SAS River Basin is Ocmulgee River at Lumber City, Ga. (station 02215500) (fig. 24), where the lithology is a heterogeneous mix of sand, silt, and clay. This station is located in the upper part of the basin where baseflow dominates streamflow. The highest index (7.31) in the SAS River Basin is the station on the Little Satilla River at Offerman, Ga. (station 02227500) (fig. 24), where the lithology is mostly clay, sand, and silt beds containing phosphate. This station is located in the lower part of the basin, where runoff dominates streamflow and the aquifer is deeply buried.

In the Suwannee River Basin, the only discharge that was analyzed was at the Alapaha River at Statenville, Ga. (station 02317500) (fig. 25), where the lithology is mostly sand, silt, clay, limestone, and dolomite. The shape of the curve indicates there is a large contribution of runoff to streamflow, which corresponds to a higher index (3.89) than observed in the upper Coastal Plain.

Linear-regression analysis was used to determine the flow duration that best estimates baseflow for streams in the area. Mean annual baseflow calculated by HYSEP for the 14 stations for the period 1971-2001 were compared to flow durations at the stations ranging from $\mathrm{Q}_{1}$ to $\mathrm{Q}_{99}$; the best fit between HYSEP estimates and flow duration was at the $\mathrm{Q}_{35}$ flow duration (flow is equaled or exceeded 35 percent of the time). The best regression model had an $\mathrm{r}$-squared $\left(\mathrm{r}^{2}\right)$ value of 0.9970 and a p-value of less than 0.0001 (table 7). Linear-regression analysis was used on the eight stations selected for HYSEP to compare results. Both sets of data show the $\mathrm{Q}_{35}$ as the best estimate of baseflow. The linear regression of flow duration is probably more representative of average climatic conditions rather than drought conditions because the analysis compares mean annual baseflow and flow duration for several stations with differing drainage areas for the 31-year period. Linear-regression analysis of flow duration shows drought conditions most likely occur above the $\mathrm{Q}_{80}$ flow duration. Figure 26 illustrates the regression of $Q_{35}$ with mean annual baseflow from HYSEP.

\section{Comparison of Results}

Major variation exists between baseflow estimation using drought-streamflow analysis and both HYSEP and linearregression analysis of flow duration. Slight variation exists between HYSEP and flow-duration methods. The same 14 stations were selected to make a comparison of the three methods. Using the drought-streamflow analysis, the minimum contribution to streamflow from baseflow was observed. During drought conditions, the following observations were made: (1) total streamflow was equivalent to baseflow; (2) surface-water runoff to streamflow and ground-water contribution was reduced; (3) ground-water levels decreased; and (4) some streams reaches went dry. Under average precipitation conditions during 1971-2001, baseflow ranged from 33 to 70 percent of total streamflow during 1997 (average conditions are best represented by 1997 data) and increased to 27 to 81 percent in drought years 1981 and 2000, respectively (table 3). For the study area, mean annual baseflow during drought conditions (1981 and 2000) ranged from 0 to 24 percent of mean annual streamflow for 1971-2001 (table 8). These values are far below the 39-74 percent estimated using HYSEP and 65-102 percent estimated using linear-regression analysis of flow duration (fig. 8). 


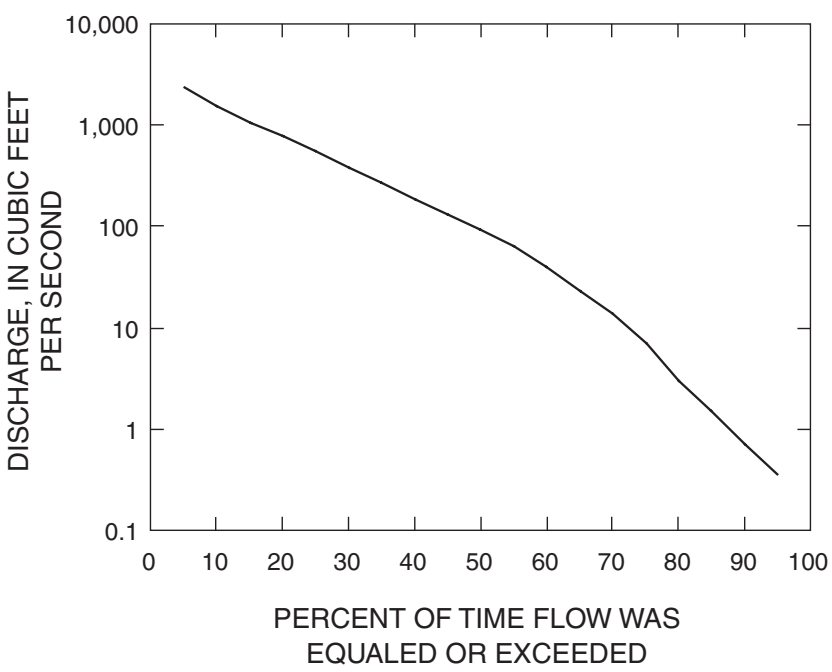

Figure 25. Duration of mean daily streamflow for Alapaha River (station 02317500) at Statenville, Georgia, in the Suwannee River Basin, 1971-2001.

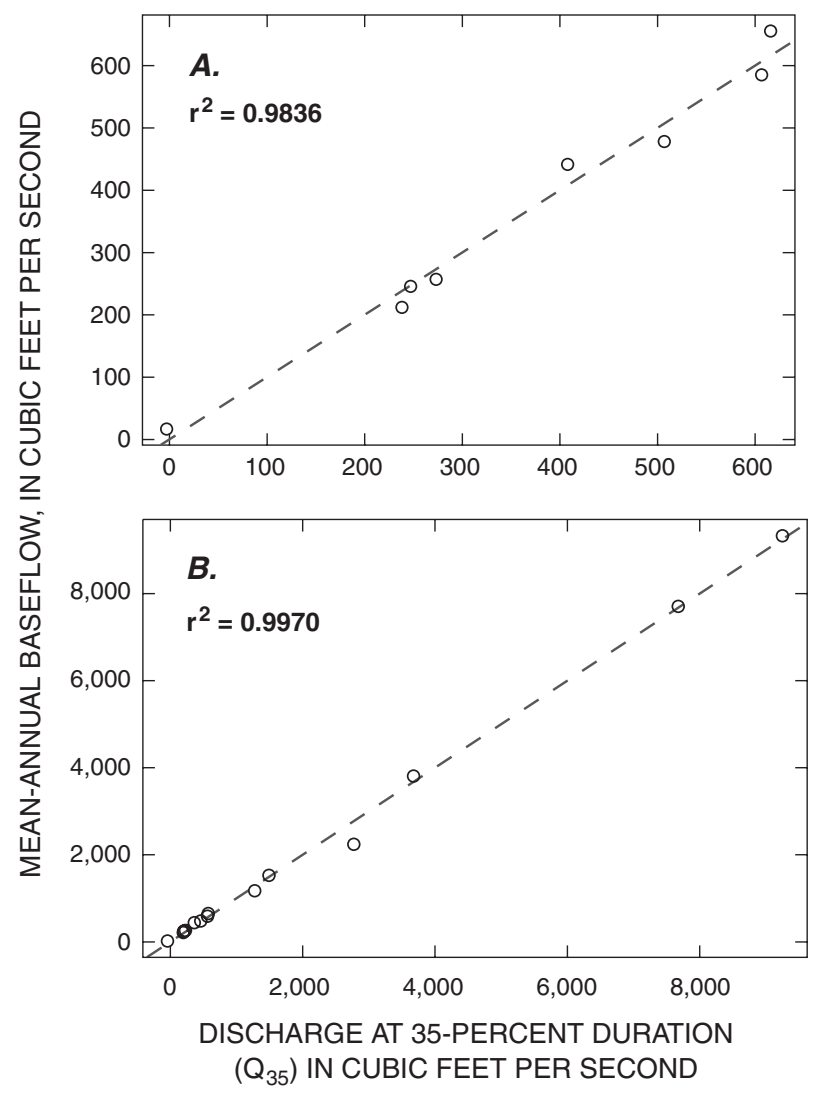

Figure 26. Regression of $\mathrm{Q}_{35}$ versus mean annual baseflow for the $(A) 8$ and $(B) 14$ streamflow gaging stations selected for hydrograph-separation technique, Georgia and South Carolina, 1971-2001.
Table 7. Coefficient of determination $\left(r^{2}\right)$ and residual standard of error for flow durations evaluated as indicators of baseflow for 8 and 14 streamflow gaging stations selected in the Salkehatchie-Savannah-Ogeechee, Altamaha-Satilla-St Marys, and Suwannee River Basins, 1971-2001.

[P-value $=$ less than 0.5 for the 8 stations; less than 0.0001 for the 14 stations]

\begin{tabular}{cccccc}
\hline \multirow{2}{*}{$\begin{array}{c}\text { Flow } \\
\text { duration }\end{array}$} & \multicolumn{2}{c}{ r-squared } & & \multicolumn{2}{c}{ Residual standard error } \\
\cline { 2 - 3 } \cline { 5 - 6 } & 8 stations & 14 stations & & 8 stations & 14 stations \\
\hline $\mathrm{Q}_{01}$ & 0.69 & 0.98 & & 128.40 & 463.7 \\
$\mathrm{Q}_{05}$ & 0.75 & 0.98 & & 116.40 & 346.3 \\
$\mathrm{Q}_{10}$ & 0.77 & 0.98 & & 110.10 & 345 \\
$\mathrm{Q}_{15}$ & 0.82 & 0.98 & & 97.04 & 311.4 \\
$\mathrm{Q}_{20}$ & 0.88 & 0.99 & & 80.82 & 238.7 \\
$\mathrm{Q}_{25}$ & 0.92 & 0.99 & & 66.41 & 202.8 \\
$\mathrm{Q}_{30}$ & 0.95 & 0.99 & & 52.09 & 179.8 \\
$\mathrm{Q}_{35}$ & 0.98 & 1.00 & & 29.71 & 168.8 \\
$\mathrm{Q}_{40}$ & 0.98 & 0.99 & & 36.56 & 169.4 \\
$\mathrm{Q}_{45}$ & 0.92 & 0.99 & & 63.81 & 205.7 \\
$\mathrm{Q}_{50}$ & 0.81 & 0.99 & & 100.60 & 224.7 \\
$\mathrm{Q}_{55}$ & 0.65 & 0.99 & & 136.60 & 257.1 \\
$\mathrm{Q}_{60}$ & 0.46 & 0.99 & & 170.20 & 266.1 \\
$\mathrm{Q}_{65}$ & 0.33 & 0.99 & & 189.60 & 275.4 \\
$\mathrm{Q}_{70}$ & 0.24 & 0.98 & & 202.50 & 307.4 \\
$\mathrm{Q}_{75}$ & 0.18 & 0.98 & & 209.30 & 347.5 \\
$\mathrm{Q}_{80}$ & 0.15 & 0.98 & & 213.90 & 377.8 \\
$\mathrm{Q}_{85}$ & 0.12 & 0.98 & & 217.80 & 412.6 \\
$\mathrm{Q}_{90}$ & 0.11 & 0.97 & & 219.30 & 456.4 \\
$\mathrm{Q}_{95}$ & 0.10 & 0.97 & & 219.50 & 481.6 \\
$\mathrm{Q}_{99}$ & 0.13 & 0.97 & & 216.70 & 518.2 \\
\hline & & & & & \\
\hline
\end{tabular}

The flow-duration method of estimating baseflow gives an overestimation of baseflow for a particular stream. Regression analyses of streamflow data indicate that the flow-duration point that most closely estimates baseflow is the 35-percent flow-duration point $\left(\mathrm{Q}_{35}\right)$ (flow is greater than or equaled to 35 percent of the time and less than or equaled to 65 percent of the time). Stricker (1983) estimated baseflow as the 65-percent flow-duration point $\left(\mathrm{Q}_{65}\right)$. The difference could merely be a matter of interpretation. $\mathrm{Q}_{35}$ is the flow that is equaled or exceeded 35 percent of the time or less than or equal 65 percent of the time, corresponding to a $Q_{65}$. Nevertheless, the linear regression of streamflow duration is not a reliable estimator of baseflow, particularly in the upper part of the basin area where streams intersect the aquifer as indicated by the 102-percent baseflow estimation of the Salkehatchie River, nor in the lower part of the study area where the aquifer is deeply buried. The variability in basin size, the lithology, and ground-water levels affect the reliability of using the flowduration method as a good estimator of baseflow.

The HYSEP method of estimating baseflow most likely relates to actual baseflow of the three methods used. HYSEP systematically separates baseflow from runoff by connecting low points of the streamflow hydrograph. HYSEP is most 
Table 8. Comparison of three methods used to calculate baseflow for selected streamflow gaging stations in the SalkehatchieSavannah-Ogeechee, Altamaha-Satilla-St Marys and Suwannee River Basins, 1971-2001.

[bold, stations selected for HYSEP; $\mathrm{mi}^{2}$, square mile; $\mathrm{ft}^{3} / \mathrm{s}$, cubic foot per second; in/yr, inch per year; \%, percent of total streamflow]

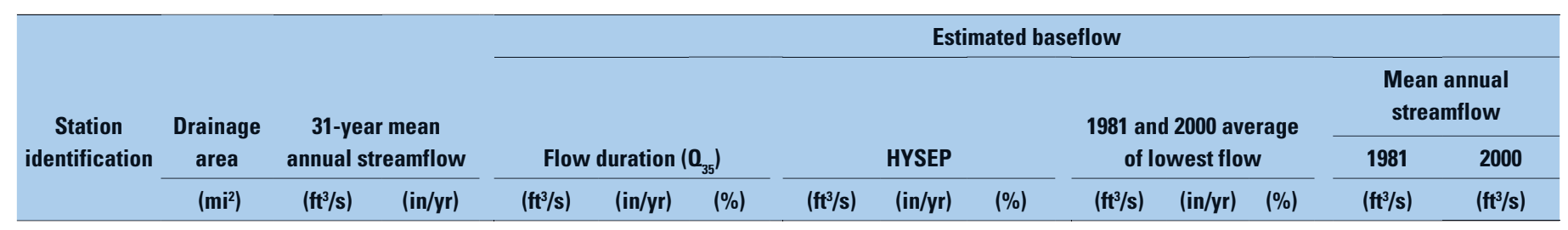

Salkehatchie-Savannah-Ogeechee River Basin

\begin{tabular}{lrrrrrrrrrrrrrrr}
\hline $\mathbf{0 2 1 7 5 5 0 0}$ & 341.0 & 357.0 & 14.23 & 365.0 & 14.50 & 102 & 246 & 9.80 & 69 & 28.0 & 1.11 & 11 & 189.0 & 174.0 \\
\hline $\mathbf{0 2 1 9 7 6 0 0}$ & 28 & 24.5 & 11.87 & 19 & 9.21 & 78 & 17 & 8.24 & 69 & 3.35 & 1.62 & 20 & 13.8 & 12.1 \\
\hline $\mathbf{0 2 1 9 8 0 0 0}$ & 646 & 598 & 12.58 & 588 & 12.4 & 98 & 442 & 9.29 & 74 & 95 & 2 & 21 & 383 & 297 \\
\hline 02202500 & 2,650 & 2,330 & 11.94 & 2,160 & 11.1 & 93 & 1,529 & 7.83 & 66 & 136 & .69 & 9 & 823 & 803 \\
\hline $\mathbf{0 2 2 0 3 0 0 0}$ & 555 & 484 & 11.84 & 401 & 9.82 & 83 & 257 & 6.29 & 54 & 2.5 & .06 & 1 & 116 & 169 \\
\hline
\end{tabular}

Altamaha-Satilla-St Marys River Basin

\begin{tabular}{rrrrrrrrrrrrrrrr}
\hline 02215500 & 5,180 & 5,510 & 14.44 & 5,210 & 13.7 & 95 & 3,811 & 10 & 69 & 928 & 2.43 & 24 & 2,570 & 2,460 \\
\hline 02223500 & 4,390 & 4,390 & 13.54 & 3,950 & 12.2 & 90 & 2,238 & 6.9 & 51 & 399 & 1.23 & 18 & 2,230 & 1,780 \\
\hline 02225000 & 11,600 & 11,700 & 13.69 & 10,800 & 12.6 & 92 & 7,704 & 9.02 & 66 & 1,570 & 1.84 & 20 & 5,330 & 4,850 \\
\hline $\mathbf{0 2 2 2 5 5 0 0}$ & 1,110 & 1,040 & 12.72 & 863 & 10.6 & 83 & 585 & 7.15 & 57 & 28 & .34 & 5 & 309 & 476 \\
\hline 02226000 & 13,600 & 13,900 & 13.87 & 12,900 & 13 & 93 & 9,330 & 9.31 & 67 & 1,590 & 1.6 & 17 & 6,050 & 5,640 \\
\hline $\mathbf{0 2 2 2 6 5 0 0}$ & 1,190 & 1,110 & 12.56 & 725 & 8.2 & 65 & 478 & 5.41 & 43 & 8.75 & .1 & 2 & 118 & 252 \\
\hline $\mathbf{0 2 2 2 7 5 0 0}$ & 646 & 542 & 11.38 & 353 & 7.42 & 65 & 212 & 4.45 & 39 & 0 & 0 & 0 & 75.4 & 85.2 \\
\hline 02228000 & 2,790 & 2,390 & 11.63 & 1,860 & 9.05 & 78 & 1,171 & 5.7 & 49 & 33 & .16 & 3 & 326 & 438 \\
\hline
\end{tabular}

Suwannee River Basin

\begin{tabular}{lllllllllllllll}
\hline $\mathbf{0 2 3 1 7 5 0 0}$ & 1,390 & 1,170 & 11.34 & 876 & 8.49 & 75 & 656 & 6.36 & 56 & 31.0 & 0.30 & 5 & 138 & 437 \\
\hline
\end{tabular}

reliable for estimating drainage areas of less than $100 \mathrm{mi}^{2}$ with at least 20 years of continuous streamflow data. Because of the limited availability of data, the drainage-area size criterion was increased and the period-of-record criterion was increased to include extremes in precipitation conditions. Table 8 compares mean annual baseflow of selected streams using the hydrograph-separation and linear-regression analysis of flow duration, and drought-streamflow analysis methods. An example of the variability in baseflow estimation is observed at station 02175500 (Salkehatchie River) (fig. 1). Part of the river is in the upper Coastal Plain where there is a high degree of interconnection between the stream and the aquifer resulting in a substantial contribution of ground water to streamflow. According to the methods used, linear-regression analysis estimates that baseflow is equivalent to the flow at $\mathrm{Q}_{35}$, which in this case is 102 percent of the mean annual streamflow. The drought-streamflow analysis estimates that baseflow is 11 percent of total streamflow. Again, this is an unreasonable estimation because the stream is in the upper Coastal Plain where there is a greater interconnectivity with the aquifer. The HYSEP method estimates baseflow as 69 percent of total streamflow, which seems most reasonable of the three methods, considering the size and location of the basin.

\section{Summary}

Stream-aquifer relations were evaluated in the 67-county area of southeast Georgia, southwest South Carolina, and northeast Florida (55 counties in Georgia, 5 counties in Florida, and 7 counties in South Carolina) during a variety of climatic conditions for the period from 1971-2001. Ground-water discharge to streams was estimated using three methods: (1) HYSEP, an automated hydrograph-separation program; (2) drought measurement of baseflow; and (3) a comparison of mean annual baseflow and flow-duration data using a simple linear-regression analysis. The hydrographseparation method provides the best estimate of mean annual ground-water discharge to streams in the study area. The analysis of drought streamflow provides an estimate of the minimum ground-water discharge to streamflow, whereas linear-regression analysis overestimates an average value for a given basin. Analyses were conducted using 8 continuous-record streamflow gaging stations for hydrograph separation, 14 continuous-record streamflow gaging stations for streamflow duration, and 62 continuous-record and partialrecord streamflow gaging stations for drought streamflow; 9 U.S. Geological Survey wells; and 11 National Weather 
Service stations. Streams and tributaries were grouped into the Salkehatchie-Savannah-Ogeechee River, Altamaha-SatillaSt Marys River, and Suwannee River Basins for this study.

Water in streams and aquifers interact through a dynamic hydrologic system including aquifers, streams, reservoirs, and floodplains. These systems are interconnected and form a hydrologic environment that is stressed by natural hydrologic, climatic, and anthropogenic factors. Under steady-state conditions, most ground-water systems can be divided into three subsystems: local flow, characterized by relatively shallow and short flowpaths that extend from a topographic high to an adjacent topographic low; intermediate flow, which includes at least one local flow system between respective points of recharge and discharge; and regional flow, which begins at or near a major ground-water divide and terminates at a regional drain.

Recharge to the hydrologic system is provided by rainfall that ranges from an average of about 47 to 53 inches per year based on the 30-year period 1971-2000. Most of the recharge is either discharged from the shallow, local flow systems into small streams, or is lost as evapotranspiration. In the intermediate flow system, some water is discharged to major tributaries. Climatic effects dominate in the surficial aquifer. Water levels generally are highest in the winter and early spring when precipitation is greatest and evapotranspiration is least; water levels are lowest during the summer and fall when precipitation is least and evapotranspiration is highest. In the lower Coastal Plain, with the exception of the unconfined section of the surficial aquifer system, the aquifers are deeply buried and confined. In this area, climatic effects are greatly diminished, and fluctuations are due to changes in ground-water pumping.

Three methods to estimate baseflow were compared because a number of variables can affect baseflow including regulation of flows; physical properties of the basin such as vegetative cover, slope, area, shape, land use, soil thickness; and infiltration capacity as well as antecedent soil moisture and depth to ground water. The river or tributary at each streamflow gaging station selected for HYSEP analysis had negligible diversion or regulation, drainage area less than 1,400 square miles, and at least 31 years of continuous record. For the 8 streamflow gaging stations selected for HYSEP, baseflow contributed from 39 to 74 percent of streamflow with a mean contribution of 58 percent.

During a high-precipitation year, baseflow accounted for 48 percent of total streamflow, 63 percent during an average-precipitation year, and 60 percent during a low-precipitation year. During dry periods, there is a reduction in runoff, and baseflow is the major contributor to streamflow. During drought conditions, there is less water available to recharge the aquifer and ground-water levels decline.

Baseflow estimates vary from the upper and lower parts of a basin. Mean annual baseflow in the upper SalkehatchieSavannah-Ogeechee River Basin during 1971-2001 ranges from 66 to 74 percent and is 54 percent in the lower basin. In the upper Altamaha-Satilla-St Marys River Basin, baseflow is about 57 percent of total streamflow; in the lower part of the basin, baseflow ranges from about 39 to 43 percent of total streamflow. In the lower part of the Suwannee River Basin, baseflow is about 56 percent of total streamflow.

Drought streamflow represents a quantitative estimate of minimum ground-water discharge to streams because during drought periods, streamflow is composed mostly of baseflow as estimated by HYSEP. During droughts, ground-water contribution to streamflow mostly is from the intermediate and regional flow systems. During the 1981 and 2000 droughts, baseflow contribution ranged from 0 to 24 percent of streamflow. This low contribution most likely is due to a lower ground-water levels during drought.

Linear-regression analysis was used to determine the flow duration that best estimates baseflow for streams in the area. Mean annual baseflow at 14 streamflow gaging stations in the study area for 1971-2001 were compared to the $Q_{1}$ to $\mathrm{Q}_{99}$ flow durations at those stations using a statistical computer program; the best fit between HYSEP estimates and flow duration was at the $\mathrm{Q}_{35}$ flow duration. Discharge data during 1971-2001 for 14 streamflow gaging stations were analyzed to determine the streamflow index. Indices ranged from a low of 1.48 at the Brushy Creek station in the Salkehatchie-Savannah-Ogeechee River Basin to a high of 7.31 at Little Satilla River in the Altamaha-Satilla-St Marys River Basin. Generally, high indices are associated with steep slopes that are indicative of limited basin storage and dominant contribution from runoff. Low indices are associated with flat slopes that are indicative of equal contribution of ground water and runoff.

Comparison of the three methods used to estimate baseflow shows that drought-streamflow conditions are a minimum estimate of mean-annual baseflow contributions. Because ground-water levels may decline during droughts, the amount of baseflow to streamflow correspondingly declines. The linear-regression analysis of streamflow duration overestimates baseflow when generalizing across a large basin because of variability in size and geology of basins. The HYSEP method of baseflow estimation most likely provides a reasonable estimate because of the stringent requirements placed on basin selection, which helps to reduce the number of errors in estimation. This comparison is illustrated in the baseflow estimation at Salkehatchie River (station 02175500). Part of the Salkehatchie River is in the upper Coastal Plain where there is a high degree of interconnection between the stream and the aquifer, resulting in a substantial contribution of ground water to streamflow. According to the methods used, linear-regression analysis estimates that baseflow is equivalent to the flow at $\mathrm{Q}_{35}$, which in this case is 102 percent of the mean annual streamflow. The drought-streamflow analysis estimates baseflow as 11 percent of total streamflow. This is an unreasonable estimation because part of the stream is in the upper Coastal Plain where there is a high degree of interconnectivity with the aquifer. The HYSEP method estimates baseflow as 69 percent of total streamflow. The same 14 stations were used to make a comparison among the three methods used to estimate baseflow. 
Overall, for the study area, mean annual baseflow during the 1981 and 2000 droughts ranged from 0 to 24 percent of mean annual total streamflow for the period 1971-2001 using drought-streamflow analysis. During 1971-2001, baseflow was estimated as ranging from 39-74 percent of streamflow using HYSEP and 65-102 percent using linear-regression analysis of flow duration.

\section{Selected References}

Abu-Ruman, Malek, and Clarke, J.S., 2001, Preliminary simulation of pond-aquifer flow and water availability at a seepage pond near Brunswick, Georgia, in Proceedings of the 2001 Georgia Water Resources Conference held March 26-27, 2001, at The University of Georgia, Kathryn J. Hatcher, ed., Institute of Ecology, The University of Georgia, Athens, Georgia, p. 669-672.

Atkins, J.B., Journey, C.A., and Clarke, J.S., 1996, Estimation of ground-water discharge to streams in the central Savannah River basin of Georgia and South Carolina: U.S. Geological Survey Water-Resources Investigations Report 96-4179, 36 p.

Bevans, H.E., 1986, Estimating stream-aquifer interactions in coal areas of eastern Kansas by using streamflow records, in Subitzky, Seymour, ed., Selected papers in the Hydrologic Sciences: U.S. Geological Survey Water-Supply Paper 2290, p. 51-64.

Brooks, R., Clarke, J.S., and Faye, R.E., 1985, Hydrogeology of the Gordon aquifer system of east-central Georgia: Georgia Geologic Survey Information Circular 75, 41 p.

Carter, R.F., 1983, Effects of the drought of 1980-81 on streamflow and ground-water levels in Georgia: U.S. Geological Survey Water-Resources Investigations Report 83-4158, 46 p.

Carter, R.F., and Putnam, S.A., 1977, Low-flow frequency of Georgia streams: U.S. Geological Survey Water-Resources Investigations Report 77-127, 104 p.

Carter, R.F., and Stiles, H.R., 1983, Average annual rainfall and runoff in Georgia, 1941-1970: Georgia Geologic Survey Hydrologic Atlas 9, 1 sheet.

Chowns, T.M., and Williams, C.T., 1983, Pre-Cretaceous rocks beneath the Georgia Coastal Plain-Regional implications, in Gohn, G.S., ed., Studies related to the Charleston, South Carolina earthquake of 1886-Tectonics and seismisity: U.S. Geological Survey Professional Paper 1313-L, p. L1-L42.

Clark, W.Z., Jr., and Zisa, A.C., 1976, Physiographic map of Georgia: Georgia Geologic Survey State map 4, 1 sheet.
Clarke, J.S., 2003, The Surficial and Brunswick aquifer systems-alternative ground-water resources for Coastal Georgia in Proceedings of the 2003 Georgia Water Resources Conference held April 23-24, 2003, at The University of Georgia, Kathryn J. Hatcher, ed., Institute of Ecology, The University of Georgia, Athens, Georgia, CD-ROM.

Clarke, J.S., Hacke, C.M., and Peck, M.F., 1990, Geology and ground-water resources of the coastal area of Georgia: Georgia Geologic Survey Bulletin 113, 106 p.

Clarke, J.S., and Krause R.E., 2000, Design, revision, and application of ground-water flow models for simulation of selected water-management scenarios in the coastal area of Georgia and adjacent parts of South Carolina and Florida: U.S. Geological Survey Water-Resources Investigations Report 00-4084, 93 p.

Clarke, J.S., and West, T.C., 1997, Ground-water levels, predevelopment ground-water flow, and stream-aquifer relations in the vicinity of the Savannah River Site, Georgia and South Carolina: U.S. Geological Survey Water-Resources Investigations Report 97-4197, 120 p.

Clarke, J.S., and West, T.C., 1998, Simulation of groundwater flow and stream-aquifer relations in the vicinity of the Savannah River Site, Georgia and South Carolina, Predevelopment through 1992: U.S. Geological Survey WaterResources Investigations Report 98-4062, 134 p.

Coffin, Robert, Grams, S.C., Leeth, D.C., and Peck, M.F., 2002, Continuous ground-water-level data and periodic surface-water- and ground-water-quality data, Calendar Year 2002, in Water Resources Data-Georgia, 2002, U.S. Geological Survey Water-Data Report GA-02-2, CD-ROM.

Colquhoun, D.J., 1981, Variation in sea level on the South Carolina Coastal Plain, in Variation in sea level on the South Carolina Coastal Plain, Colquhoun, D.J., ed., International Geological Correlation Program, no. 61, p. 1-44.

Cressler, A.M., Blackburn, D.K., and McSwain, K.B., 2001, Ground-water conditions in Georgia, 2001: U.S. Geological Survey Open-File Report 01-220, 184 p.

Falls, W.F., Baum, J.S., Harrelson, L.G., Brown, L.H., and Jerden, James, L., Jr., 1997, Geology and hydrogeology of Cretaceous and Tertiary strata, and confinement in the vicinity of the U.S. Department of Energy Savannah River Site, South Carolina and Georgia: U.S. Geological Survey WaterResources Investigations Report 97-4245, 125 p.

Fanning, J.L., 1999, Water use in coastal Georgia by county and source, 1997; and water-use trends, 1980-97: Georgia Geologic Survey Information Circular 104, 37 p.

Fanning, J.L., 2003, Water use in Georgia by county for 2000 and water-use trends for 1980-2000: Georgia Geologic Survey Information Circular 106, 176 p. 
Faye, R.E., and Mayer, G.C., 1990, Ground-water flow and stream-aquifer relations in the northern Coastal Plain of Georgia and adjacent parts of Alabama and South Carolina: U.S. Geological Survey Water-Resources Investigations Report 88-4143, 83 p.

Faye, R.E., and Mayer, G.C., 1996, Simulation of groundwater flow in Southeastern Coastal Plain clastic aquifers in Georgia and adjacent parts of Alabama and South Carolina: U.S. Geological Survey Professional Paper 1410-F, 77 p.

Freeze, R.A., and Witherspoon, P.A., 1966, Theoretical analysis of regional groundwater flow -1 . Analytical and numerical solutions to the mathematical model: Water Resources Research, v. 2, no., 4, p. 641-656.

Freeze, R.A., and Witherspoon, P.A., 1967, Theoretical analysis of regional groundwater flow -2 . Effect of water-table configuration and subsurface permeability variation: Water Resources Research, v. 3, no., 2, p. 623-634.

Freeze, R.A., and Witherspoon, P.A., 1968, Theoretical analysis of regional groundwater flow - 3. Quantitative interpretations: Water Resources Research, v. 4, no. 3, p. 581-590.

Gregg, D.O., and Zimmerman, E.A., 1974, Geologic and hydrologic control of chloride contamination in aquifers at Brunswick, Glynn County, Georgia: U.S. Geological Survey Water-Supply Paper 2029-D, 44 p.

Hale, T.W., Hopkins, E.H., and Carter, R.F., 1989, Effects of the 1986 drought on streamflow in Alabama, Georgia, North Carolina, South Carolina, Tennessee, and Virginia: U.S. Geological Survey Water-Resources Investigations Report 89-4212, 102 p.

Hickey, A.C., Kerestes, J.F., and McCallum, B.E., 2002, Continuous water-level, streamflow, water-quality data, and periodic water-quality data, Water Year 2002 in Water Resources Data-Georgia, 2002: U.S. Geological Survey Water-Data Report GA-02-1, CD-ROM.

Horton, R.E., 1933, The role of infiltration in the hydrologic cycle: Transactions of American Geophysical Union, v. 14, p. 446-460.

Huddlestun, P.F., 1988, A revision of the lithostratigraphic units of the Coastal Plain of Georgia, Miocene through Holocene: Georgia Geologic Survey Bulletin 104, 162 p.

Huddlestun, P.F., 1993, The Oligocene stratigraphic framework on the Coastal Plain of the Southeastern United States: Abstracts with Programs, Geological Society of America, v. 25 , no. 4 , p. 24.

Huddlestun, P.F., and Hetrick, J.H., 1986, Upper Eocene stratigraphy of central and eastern Georgia: Georgia Geologic Survey Bulletin 95, 78 p.
Huddlestun, P.F., and Summerour, J.H., 1996, The lithostratigraphic framework of the uppermost Cretaceous and lower Tertiary of eastern Burke County, Georgia: Georgia Geologic Survey Bulletin 127, 94 p.

Kellam, M.F., and Gorday, G.L., 1990, Hydrogeology of the Gulf Trough-Apalachicola Embayment area, Georgia: Georgia Geologic Survey Bulletin 94, 74 p.

Krause, R.E., and Clarke, J.S., 2001, Saltwater contamination of ground water at Brunswick, Georgia and Hilton Head Island, South Carolina, in Proceedings of the 2001 Georgia Water Resources Conference held March 26-27, 2001, at The University of Georgia, Kathryn J. Hatcher, ed., Institute of Ecology, The University of Georgia, Athens, Georgia, p. 756-759.

Krause, R.E., and Randolph, R.B, 1989, Hydrology of the Floridan aquifer system in southeast Georgia and adjacent Florida and South Carolina: U.S. Geological Survey Professional Paper 1403-D, 65 p.

Leeth, D.C., 1999, Hydrogeology of the Upper Floridan Aquifer in the vicinity of the Marine Corps Logistics Base near Albany, Georgia: U.S. Geological Survey WaterResources Investigations Report 98-4202, 49 p.

Leeth, D.C., Clarke, J.S., Craigg, S.D., and Wipperfurth, C.J., 2003, Ground-water conditions and studies in Georgia, 2001: U.S. Geological Survey Water-Resources Investigations Report 03-4032, 96 p.

Linsley, R.K., Kohler, M.A., and Paulhus, J.L.H., 1982, Hydrology for Engineers (3rd ed.): New York, McGrawHill, 508 p.

McCallum, B.E., Cressler, A.M., Blackburn, D.K., and McSwain, K.B., 2000, Water resources data, Georgia, 2000-Continuous ground-water level data, and periodic surface-water- and ground-water-quality data, Calendar Year 2000: U.S. Geological Survey Water-Data Report GA-00-2, CD-ROM.

McCallum, B.E., and Hickey, A.C., 2000, Water resources data, Georgia, 2000-Continuous water-level, streamflow, water-quality data, and periodic water-quality data, Water Year 2000: U.S. Geological Survey Water-Data Report GA-00-1, CD-ROM.

Miller, J.A., 1986, Hydrogeologic framework of the Floridan aquifer system in Florida and in parts of Georgia, Alabama, and South Carolina: U.S. Geological Survey Professional Paper 1403-B, $91 \mathrm{p}$.

Mosner, M.S., 2002, Stream-aquifer relations and the potentiometric surface of the Upper Floridan aquifer in the Lower Apalachicola-Chattahoochee-Flint River Basin in parts of Georgia, Florida, and Alabama, 1999-2000: U.S. Geological Survey Water-Resources Investigations Report 02-4244, 45 p. 
National Oceanic and Atmospheric Administration, 2002, Monthly station normals of temperature, precipitation, and heating and cooling degree days 1971-2000: Asheville, N.C., no. 81,28 p.

Peck, M.F., Clarke, J.S., Abu-Ruman, Malek, and Laitta, M.T., 2001, Hydrogeologic conditions at two seepage ponds in the coastal area of Georgia, August 1999 to February 2001, in Proceedings of the 2001 Georgia Water Resources Conference held March 26-27, 2001, at The University of Georgia, Kathryn J. Hatcher, ed., Institute of Ecology, The University of Georgia, Athens, Georgia, p. 768-771.

Peck, M.F., Clarke, J.S., Ransom, Camille, III, and Richards, C.J., 1999, Potentiometric surface of the Upper Floridan aquifer in Georgia and adjacent parts of Alabama, Florida, and South Carolina, May 1998; and water-level trends in Georgia, 1990-1998: Georgia Geologic Survey Hydrologic Atlas 22, 1 sheet.

Pettyjohn, W.A., and Henning, Roger, 1979, Preliminary estimate of ground-water recharge rates, related streamflow, and water quality in Ohio: Ohio State University, Water Resources Center, 321 p.

Price, Van, Jr., Fallaw, W.C., and McKinney, J.B., 1991, Geologic setting of the new production reactor reference site within the Savannah River Site (U): Aiken, S.C., Westinghouse Savannah River Company, report no. WSRC-RP-91-96, ESH-EMS-90171, 80 p.

Prowell, D.C., and O'Conner, B.J., 1978, Belair fault zone-Evidence of Tertiary fault displacement in eastern Georgia: Geology, v. 6, no. 11, p. 681-684.

Prowell, D.C., Christopher, R.A., Edwards, L.E., Bybell, L.M., and Gill, H.E., 1985, Geologic section of the updip Coastal Plain from central Georgia to western South Carolina: U.S. Geological Survey Miscellaneous Field Studies Map, MF-1737, 10 p.

Randolph, R.B., Pernik, L.M., and Garza, Regina, 1991, Water-supply potential of the Floridan aquifer system in the Coastal area of Georgia-A digital model approach: Georgia Geologic Survey Bulletin 116, 30 p.

Reynolds, R.J., 1982, Ground-water contributions of streams on Long Island, New York: U.S. Geological Survey WaterResources Investigations Report 81-48, 33 p.

Reynolds, R.J., 1969, Mean streamflows from discharge measurements: International Association of Scientific Hydrology Bulletin, v. XIV, no. 4, p. 95-110.
Riggs, H.C., 1963, The base-flow recession curve as an indicator of ground water: International Association of Scientific Hydrology Publication 63, p. 353-363.

Rutledge, A.T., 1993, Computer programs for describing the recession of ground-water discharge and for estimating mean ground-water recharge and discharge from streamflow records: U.S. Geological Survey Water-Resources Investigations Report 93-4121, 45 p.

Searcy, J.K., 1959, Flow-duration curves: U.S. Geological Survey Water-Supply Paper 1542-A, 33 p.

Sloto, R.A., and Crouse, M.Y., 1996, HYSEP - A computer program for streamflow hydrograph separation and analysis: U.S. Geological Survey Water-Resources Investigations Report 96-4040, 67 p.

Southeast Regional Climate Center, accessed October 10, 2002, at http://cirrus.dnr.state.sc.us/cgi-bin/sercc/cliMAIN. pl?sc0448.

Stricker, V.A., 1983, Baseflow of streams in the outcrop areas of southeastern sand aquifer: South Carolina, Georgia, Alabama, and Mississippi: U.S. Geological Survey WaterResources Investigations Report 83-4106, 17 p.

Thomson, M.T., and Carter, R.F., 1955, Surface water resources of Georgia during the drought of 1954: Georgia Department of Mines, Mining, and Geology Information Circular 17, 79 p.

Toth, J.A., 1962, A theory of groundwater motion in small drainage basins in central Alberta, Canada: Journal of Geophysical Research, v. 67, no. 11, p. 4375-4387.

Toth, J.A., 1963, A theoretical analysis of groundwater flow in small drainage basins: Journal of Geophysical Research, v. 68 , no. 16 , p. $4795-4812$.

Vincent, H.R., 1982, Geohydrology of the Jacksonian aquifer in central and east-central Georgia: Georgia Geologic Survey Hydrologic Atlas 8, 3 sheets.

Weems, R.E., and Edwards, L.E., 2001, Geology of Oligocene, Miocene, and younger deposits in the coastal area of Georgia: Georgia Geologic Survey Bulletin 131, 124 p. 
Prepared by U.S. Geological Survey, Water Resources Discipline, Georgia District, Atlanta, Georgia.

Figure design and production by Bonnie J. Turcott and Caryl J. Wipperfurth .

Editing and page layout by Patricia L. Nobles. 


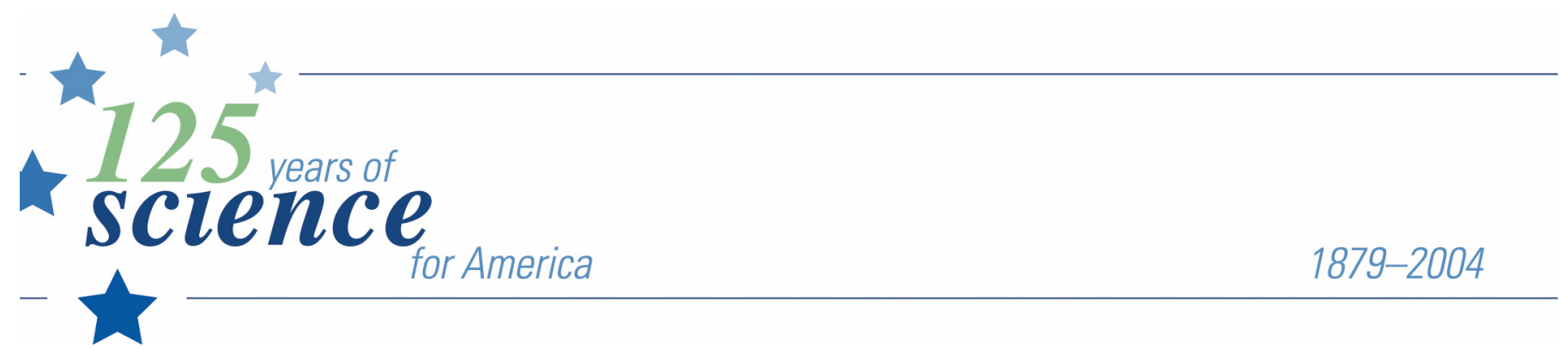

